\title{
Sequencing Batch Reactor Technology for Landfill Leachate Treatment: A State-of-the- Art Review
}

\author{
A.H. Jagaba, ${ }^{\text {a,b, }}$, S.R.M. Kutty ${ }^{\mathrm{a}}$, I.M. Lawal ${ }^{\mathrm{b}, \mathrm{c}}$, S. Abubakar ${ }^{\mathrm{b}}$, I. Hassan ${ }^{\mathrm{b}}$, I. Zubairu' ${ }^{\mathrm{b}}$, I. Umaru ${ }^{\mathrm{b}}$, A.S. \\ Abdurrasheed $^{\mathrm{a}, \mathrm{d}}$, A.A. Adam ${ }^{\mathrm{e}}$, A.A.S. Ghaleb ${ }^{\mathrm{a}}$, N.M.Y. Almahbashi ${ }^{\mathrm{a}}$, B.N.S. Al-dhawi ${ }^{\mathrm{a}}$, A. Noor ${ }^{\mathrm{a}}$ \\ ${ }^{a}$ Department of Civil and Environmental Engineering, Universiti Teknologi PETRONAS, Bandar \\ Seri Iskandar, Perak Darul Ridzuan, Malaysia \\ ${ }^{b}$ Department of Civil Engineering, Abubakar Tafawa Balewa University, Bauchi, Nigeria \\ ${ }^{c}$ Department of Civil and Environmental Engineering, University of Strathclyde, Glasgow, UK \\ ${ }^{d}$ Department of Civil Engineering, Ahmadu Bello University, Zaria, Nigeria \\ ${ }^{e}$ Department of Fundamental and Applied Sciences, Universiti Teknologi PETRONAS, Bandar \\ Seri Iskandar, Perak Darul Ridzuan, Malaysia
}

\begin{abstract}
Landfill has been a major contributor to surface and groundwater pollution if not constructively managed owing to the risk of leachate penetration into the land and aquifers. The generated leachate is considered a major public health threat to the environment. Thus, it must be retrieved and handled properly before discharging into the environment. Currently, there is no single widely acceptable method documented for proper treatment of leachate as conventional wastewater treatment processes cannot achieve a satisfactory level for degrading toxic substances present. This leads to an increasing interest in exploring various treatment processes for leachates to achieve maximum operational flexibility. Based on leachate characteristics, discharge requirements, technical possibilities, regulatory requirements and financial considerations, numerous techniques have been put in during leachate degradation, showing different degrees of effectiveness. Therefore, this review article presents a comprehensive review of existing research articles on the pros and cons of various leachate degradation methods. In line with environmental sustainability, the article stressed on the application and efficiency of sequencing batch reactor treating landfill leachate due to its operational flexibility, resistance to shock loads and high biomass retention. Contributions of integrated leachate treatment technologies with the reviewed system were also discussed. The article further analyzed the effect of different adopted materials, processes, strategies and configurations on leachate treatment. Environmental and operational parameters that affect the system were critically discussed. It is believed that information contained in this review will increase readers fundamental knowledge, guide future researchers and be incorporated into future works on experimentallybased studies for the treatment of leachate.

Keywords: Landfill leachate; Biofilm carriers; Membranes; Carbon-nanotubes; Biofilters, Sequencing Batch Reactor

\subsection{Introduction}

\subsection{Landfill Leachate}

Landfill is a large area of land, normally lined and used for disposal of waste materials (Tsilogeorgis, Zouboulis, Samaras, \& Zambouhs, 2008). It remains the major repository for disposal of residual wastes and incineration residues globally (Aluko \& Sridhar, 2013). Therefore, the unlawful disposal of solid waste at locations unprepared for landfilling could lead to unregulated leachate migration into the soil, surface water and even groundwater (Michalska, Gren, Zur, Wasilkowski, \& Mrozik, 2019). Leachate considered as an exceptionally saline complex sewerage as well an unavoidable product of a sanitary landfill (Ganjian et al., 2018; Mousavi, Almasi, Kamari, Abdali, \& Yosefi, 2015) can be defined as a reservoir with elevated concentrations of contaminants of emerging concern (Michalska, Pinski, Zur, \& Mrozik, 2020). It is the liquid formed due to the percolation of precipitation through an open landfill or the cap of a finished site and infiltration of groundwater into the landfill through wastes and biochemical processes (Aziz, Aziz, \& Yusoff, 2011a; Aziz, Aziz, Yusoff, \& Bashir, 2011; Narayan, Zargham, Ngambia, \& Riyanto, 2019).
\end{abstract}

\subsection{Leachate formation}

The existence of moisture within landfilled solid waste greater than its field potential induces a variety of various physical and microbial processes to transform contaminants into liquid resulting in leachate formation (ElFadel, Matar, \& Hashisho, 2013; Mousavi et al., 2015). Landfill leachates are generated at landfill sites when moisture blends with the landfill refuse (Chinade, Umar, Osinubi, \& Technology, 2017; Fudala-Ksiazek, Luczkiewicz, Fitobor, 
\& Olanczuk-Neyman, 2014; Mojiri et al., 2017). The co-disposal of liquid wastes, infiltration of groundwater, recirculation, snowmelt, drainage, erosion, decomposition of refuse and initial moisture content significantly influence leachate formation. It is also influenced by density, compaction, particle size, permeability, settlement, vegetation, cover, sidewall and liner material, refuse age and surface modification, gas and heat generation and transport as they affect landfill moisture distribution (El-Fadel et al., 2013). It is estimated that from about a 907 tons of municipal solid waste, approximately $0.05-0.2$ tons of leachate can be generated during the whole operational lifetime of the landfill (Narayan et al., 2019).

The quality and quantity of leachate are highly variable and affected by many parameters such as moisture, waste type and composition, seasonal weather variation, landfilling age, cover and technique, piling and compaction method, amount of precipitation, decomposition rate (Fudala-Ksiazek et al., 2014; Mousavi et al., 2015). Leachate quality is determined by the decomposition of solid wastes through physical, chemical and biological processes (Ranjan, Chakraborty, Verma, Iqbal, \& Kumar, 2016). Leachate quality usually exceeds wastewater discharge criteria with organic carbon expressed in COD and ammoniacal nitrogen as its main pollutant aspects (Trabelsi, Salah, \& Ounaeis, 2013).

\subsection{Classes of leachate}

There are three classes of leachate in terms of landfill age: the young, middle-age, and mature landfill leachate (Miao et al., 2014). According to age, landfill leachate can be classified as young (age $<5$ years), middle-age (age between 5 years and 10 years), and mature landfill leachate (age $>10$ years). Young landfill (the acid-phase landfills) leachate are usually high-strength wastewaters typically characterized by high amounts of volatile fatty acids (VFA) (Neczaj, Okoniewska, \& Kacprzak, 2005), high concentrations of organic compounds, fairly high amount of ammonia $(<400 \mathrm{mg} / \mathrm{L}$ ), low $\mathrm{pH}$, and the presence of several hazardous compounds (Neczaj, Kacprzak, Kamizela, Lach, \& Okoniewska, 2008; Tsilogeorgis et al., 2008) while mature landfill (the methanogenic-phase landfills) leachate is characterized by large proportion of high molecular-weight organics (Ying, Xu, Li, Wang, \& Jia, 2012), low concentration of biodegradable organic substances $(\mathrm{COD}<3000 \mathrm{mg} / \mathrm{L})$, low $\mathrm{BOD}_{5} / \mathrm{COD}$ ratio $(<0.1)$, low BOD/TKN ratio (Spagni, Marsili-Libelli, \& Lavagnolo, 2008) and high concentration of ammonia (> $1000 \mathrm{mg} / \mathrm{L}$ ) which constitute an environmental problem due to its fertilizing and toxic effects. In contrast, middle-age landfill leachate shows a COD/TN ratio of 3-6 and a moderate biodegradability (Z. M. Li et al., 2014; Mousavi et al., 2015). The biodegradable fraction of organic contaminants in leachate declines as the age of landfill rises, which may be due to anaerobic decomposition that occurs at landfill. Young leachate contains far fewer refractory organics than the mature (Aziz, Aziz, et al., 2011a; Aziz, Aziz, Yusoff, et al., 2011).

\subsection{Composition of leachate}

Leachate composition depends on different factors, such as the kind and amount of waste, degree of waste grinding, compaction and degradation processes (hydrolysis, adsorption, biodegradation, speciation, dissolution, dilution, ion exchange, redox, contact time, partitioning, precipitation gas, heat generation and transport) (Foo \& Hameed, 2009), waste humidity, climate conditions, site hydrology, storing technology, vegetation cover and operation of the landfill (Aluko \& Sridhar, 2013; Ganjian et al., 2018; Grosser, Neczaj, Madela, \& Celary, 2019; Mojiri, Aziz, Zaman, Aziz, \& Zahed, 2014). Other factors to include: refuse pretreatment, irrigation, recirculation and liquid waste co-disposal (A. H. Jagaba et al., 2019). The composition of landfill leachate is highly influenced by landfill age, solid waste components, rainfall rate and landfilling technology employed (Remmas, Ntougias, Chatzopoulou, \& Melidis, 2018). While, the volume of leachate generated depends on waste composition, age and size of the landfill, the compaction of waste in the landfill depends on landfill site geology and weather conditions (Narayan et al., 2019). Landfill leachate composition can thus be divided into: dissolved organic substances (alcohols, humic, fulvic and VFA), inorganic compounds (e.g., $\mathrm{Ca}^{2+}, \mathrm{Na}^{+}, \mathrm{K}^{+}, \mathrm{Mg}^{2+}, \mathrm{Fe}^{2+}, \mathrm{Mn}^{2+}, \mathrm{NH}_{4}{ }^{+}-\mathrm{N}, \mathrm{SO}_{4}^{2-}, \mathrm{Cl}^{-}$and $\mathrm{HCO}_{3}{ }^{-}$) heavy metals (e.g., $\mathrm{Cd}, \mathrm{Pb}, \mathrm{Cr}, \mathrm{Ni}, \mathrm{Hg}, \mathrm{Cu} \& \mathrm{Zn}$ ), and xenobiotic organic materials (e.g. polycyclic aromatic hydrocarbons, phenolic compounds, pesticides, plasticizers, chlorinated and halogenated organics) (Aziz, Aziz, Yusoff, et al., 2011; Ganjian et al., 2018; Luo, Zeng, Cheng, He, \& Pan, 2020; Mojiri et al., 2014). Leachate is also rich in persistent organic compounds, pathogenic organisms, pharmaceuticals, cyanides, total dissolved salts, $\mathrm{NH}_{3}-\mathrm{N}$, total alkalinity, COD, total hardness, solvent and carcinogens with a foul odor (Aziz, Aziz, et al., 2011a; Aziz, Aziz, \& Yusoff, 2011b; Aziz, Aziz, Yusoff, Mojiri, \& Abu Amr, 2012; Michalska et al., 2020; Neczaj et al., 2008; Yong, Bashir, Ng, Sethupathi, \& Lim, 2018).

\subsection{Characteristics of leachate}

Leachate characteristics seasonally varies from site to site, and also over the life of a landfill, with constant changes in flow generated, age, chemical composition, physicochemical characteristics and concentration (Contrera 
et al., 2014; Grosser et al., 2019). Leachate characteristics present high variation due to several factors as landfill operation, applied landfilling technology, waste age and climatic conditions (Remmas et al., 2018; Spagni \& MarsiliLibelli, 2009). Leachate contains significant amounts of biodegradable and non-biodegradable organic matter, heavy metals, phenols, $\mathrm{NH}_{4}{ }^{+}-\mathrm{N}$, sulphide and phosphate. It may also exhibit alkalinity, acidity or hardness (Aziz, Aziz, et al., 2011b). Thus, BOD/COD ratio has widely been used as a measure for biodegradation capacity (Ganjian et al., 2018). Highly conductive leachate indicates a high concentration of dissolved solids which would provide adsorptive sites for biofilm inoculated for pollutants degradation. Low BOD/COD ratio and slightly high pH indicates that landfill leachate is in a stabilized state with minimal biodegradability of the organic components present (Ranjan et al., 2016). The COD/TOC ratio of the leachate $<2$, is an indication of non-biodegradability (Ying, Xu, et al., 2012). Low DO concentration in leachate supports anaerobic conditions in the receiving water body and slow down the natural decomposition process supported by aerobic microorganisms (Aluko \& Sridhar, 2013). High concentrations of chemical, microbial, organic and inorganic pollutants depicted in Table 1 as the unique characteristics of municipal landfill leachate can potentially have hazardous and toxic effects on the environment and ecosystem (Pirsaheb, Hossini, Secula, Parvaneh, \& Ashraf, 2017).

\subsection{Effects of leachate leakage}

Large quantities of leachate derived from landfill site pose a significant challenge in municipal solid waste disposal (MSW) (Neczaj et al., 2005). Leachate is one of the main environmental problems in landfilling (Yarimtepe \& Oz, 2018). Its most critical features are connected to the high concentrations of contaminants (Mojiri et al., 2014), continuous change of flow and its toxicity attributed to the presence of heavy metal and ammonia (Trabelsi et al., 2013). Given the hazardous and recalcitrant nature of its constituents, leachate leakage to land and aquifers is considered a significant environmental problem to public health (Remmas et al., 2018). If raw leachate is discarded of directly in a natural environment, it infiltrates and flows into nearby water bodies and severely contaminates surface and groundwater sources (Aziz et al., 2012; Tella \& Balogun, 2020). Thereby posing adverse health effect to the surrounding soil and affecting the entire ecological system including human health (Yong et al., 2018). Leachate is a dangerous and highly polluting liquid that contributes to surface and groundwater contamination unless controlled effectively (Aluko \& Sridhar, 2013). Thus, the law requires the treatment of hazardous constituents of leachate prior to discharge to avoid pollution of water supplies as well serious and persistent toxicity (Aziz, Aziz, et al., 2011b).

\subsection{Standard regulations for leachate management and discharge}

Unless efficiently disposed, landfill may become an underlying source of pollution due to the risk of leachate infiltration into soil and groundwater. Therefore, it is imperative that the leachate produced is collected and handled efficiently before returning to the environment. Correct management of landfill site can drastically reduce the intensity and volume of leachate generated, though it cannot be eliminated (Tsilogeorgis et al., 2008). If raw leachate is disposed without any treatment, it may become a major source of water contamination because it can work its way into soils and subsoils, making the receiving water to become highly polluted (Chu, Zhang, \& Xu, 2008). The produced leachate can produce significant environmental problems and must be collected and handled appropriately prior discharging into the environment (Neczaj et al., 2008). Having a huge spectrum of intermediate organic degradation products and inorganic pollutants resulting from microbial activity in a landfill, compression and water flow, leachates from landfills pose dangerous environmental and health risks (Y. Xiao et al., 2009). Hence, landfill leachate management is regarded as a valuable subject intertwined with the environmental processing of sanitary landfills (Tan et al., 2016). Different governing laws as highlighted in Table 2 require the treatment of hazardous constituents of leachate prior to discharge in other to avoid pollution of water supplies and avoid severe and persistent toxicity (Aziz, Aziz, et al., 2011b). Hence, leachate treatment deems a major task in order to meet discharge limits (Trabelsi et al., 2013). The variation in values for standard limit of different regions might be attributed to certain environmental and economic circumstances (Sule Abubakar, Lawal, Hassan, \& Jagaba, 2016; A. Jagaba, Kutty, Hayder, Baloo, Abubakar, et al., 2020), as well as the adopted technology for leachate treatment. 
Table 1: Characteristics of landfill leachate

\begin{tabular}{|c|c|c|c|c|c|c|c|c|c|c|c|c|c|c|c|c|}
\hline Parameter & \multicolumn{16}{|c|}{ Leachate characteristics } \\
\hline $\mathrm{pH}$ & 7.87 & 7.2 & & 8.02 & 9.3 & 7.8 & 8.25 & 6.7 & 8.44 & 8.4 & 8.32 & 8.0 & 8.08 & 7.3 & 8.0 & 8.0 \\
\hline $\begin{array}{l}\text { Temperature } \\
\left({ }^{\circ} \mathrm{C}\right)\end{array}$ & 33.6 & & & & & & 28.7 & & 26.1 & & 19.7 & & & & & \\
\hline Phenol (mg/L) & 2.06 & & 2.74 & & & & 1.69 & & & & & & & & & \\
\hline Colour (Pt.Co) & 3627 & & & & & & 1690 & & 4510 & & & & & & & \\
\hline $\begin{array}{l}\text { Electrical } \\
\text { conductivity } \\
(\mathrm{ms} / \mathrm{cm})\end{array}$ & 8.31 & 450 & & & & & 3.94 & & 24.9 & & 35 & & & 71.2 & 11.7 & \\
\hline $\begin{array}{l}\text { Total solids } \\
(\mathrm{mg} / \mathrm{L})\end{array}$ & 5640 & & & & & & 5723 & 34200 & 220 & & & & & & & \\
\hline $\begin{array}{l}\text { Suspended } \\
\text { solids (mg/L) }\end{array}$ & 689 & 480 & & & & 39 & 710 & & & & & & 240 & 19883 & & \\
\hline $\begin{array}{l}\text { Alkalinity } \\
(\mathrm{mg} / \mathrm{L})\end{array}$ & 15350 & 620 & & 7000 & & 12960 & & & & 2014 & & 7000 & 131 & 1900.5 & & \\
\hline $\mathrm{BOD}_{5}(\mathrm{mg} / \mathrm{L})$ & 373 & 1300 & & 150 & 1453 & & 269 & 19400 & 1100 & & & 100 & & 27300 & 11700 & 4500 \\
\hline $\mathrm{COD}(\mathrm{mg} / \mathrm{L})$ & 1655 & 2200 & & 4000 & 5992 & 2770 & 1301 & 41800 & 6420 & 2456 & 20800 & 2200 & 2055 & 38769 & 21000 & 6500 \\
\hline $\mathrm{BOD}_{5} / \mathrm{COD}$ & 0.218 & & & & & & 0.20 & & 0.24 & & & & & & & \\
\hline $\begin{array}{l}\text { Ammonia-N } \\
(\mathrm{mg} / \mathrm{L})\end{array}$ & 600 & 210 & 850 & 3000 & 1168 & 3096 & 532 & 2250 & 1403 & 238 & 2645 & 2000 & 1199 & 2053 & 824 & 1000 \\
\hline Total Nitrogen & & 240 & 879.2 & & 1253 & & & 2520 & & 375 & & 2030 & & & & 1100 \\
\hline TKN (mg/L) & & & & & & 3263 & & & & & & & 1319 & 2571.4 & & \\
\hline TOC (mg/L) & & & & & & & 44.2 & 14060 & & & & & & & & \\
\hline $\begin{array}{l}\text { Nitrite-N } \\
(\mathrm{mg} / \mathrm{L})\end{array}$ & 53.6 & & & 1.5 & 1.12 & 0.74 & 54.10 & & & & & 0.5 & & & & \\
\hline $\begin{array}{l}\text { Nitrate-N } \\
(\mathrm{mg} / \mathrm{L})\end{array}$ & 15.8 & & 125.7 & 1.5 & 0.17 & 0.70 & & & & 16.5 & & 0.4 & & & & \\
\hline $\begin{array}{l}\text { Total } \\
\text { Phosphorus } \\
(\mathrm{mg} / \mathrm{L})\end{array}$ & 37 & 10.8 & 27.4 & & & & 17.8 & & & & & & 8.0 & 73.7 & & \\
\hline $\begin{array}{l}\text { Magnesium } \\
(\mathrm{mg} / \mathrm{L})\end{array}$ & 294 & & 76.6 & & & & 25.34 & & & & & & & & & \\
\hline $\begin{array}{l}\text { Manganese } \\
(\mathrm{mg} / \mathrm{L})\end{array}$ & & & 0.77 & & & & 1.98 & & 0.83 & & & & & & & \\
\hline Nickel (mg/L) & & & 0.58 & & & & 4.94 & & 0.46 & & & & & & & \\
\hline $\begin{array}{l}\text { Calcium } \\
(\mathrm{mg} / \mathrm{L})\end{array}$ & 1600 & & & & & & 121.45 & & & & & & & & & \\
\hline $\begin{array}{l}\text { Chromium } \\
(\mathrm{mg} / \mathrm{L})\end{array}$ & & & 1.39 & & & & 0.21 & & & & & & & & & \\
\hline
\end{tabular}




\begin{tabular}{|c|c|c|c|c|c|c|c|c|c|c|c|c|c|c|c|c|}
\hline $\begin{array}{l}\text { Chloride } \\
(\mathrm{mg} / \mathrm{L})\end{array}$ & 324 & & 1890.2 & & & & & & & & & & & & 1250 & \\
\hline Copper (mg/L) & & & 0.45 & & & & 1.17 & & 13.01 & & & & & & & \\
\hline Sulfide $(\mathrm{mg} / \mathrm{L})$ & 0.82 & & & & & & 0.3 & & & & & & & & & \\
\hline Sulfate $(\mathrm{mg} / \mathrm{L})$ & & & 48.1 & & & & & & & & & & & & & \\
\hline Silver (mg/L) & & & & & & & & & 0.94 & & & & & & & \\
\hline $\begin{array}{l}\text { Selenium } \\
(\mathrm{mg} / \mathrm{L})\end{array}$ & & & & & & & & & 0.65 & & & & & & & \\
\hline $\begin{array}{l}\text { Phosphate } \\
(\mathrm{mg} / \mathrm{L})\end{array}$ & & & 80.9 & & & & & & & 8.2 & & & 6.8 & & & \\
\hline $\begin{array}{l}\text { Aluminum } \\
(\mathrm{mg} / \mathrm{L})\end{array}$ & & & 3.25 & & & & 0.034 & & & & & & & & & \\
\hline Barium (mg/L) & & & & & & & & & 1.10 & & & & & & & \\
\hline $\begin{array}{l}\text { Total Iron } \\
(\mathrm{mg} / \mathrm{L})\end{array}$ & 4.13 & & 28.6 & & & & 6.03 & & 23.18 & & & & & & & \\
\hline $\begin{array}{l}\text { Total cobalt } \\
(\mathrm{mg} / \mathrm{L})\end{array}$ & & & & & & & 0.81 & & & & & & & & & \\
\hline $\begin{array}{l}\text { Total lithium } \\
(\mathrm{mg} / \mathrm{L})\end{array}$ & & & & & & & 0.64 & & & & & & & & & \\
\hline $\begin{array}{l}\text { Total } \\
\text { molybdenum } \\
(\mathrm{mg} / \mathrm{L})\end{array}$ & & & & & & & 0.78 & & & & & & & & & \\
\hline Lead (mg/L) & & & 0.001 & & & & & & 3.46 & & & & & & & \\
\hline Arsenic (mg/L) & & & & & & & & & 0.43 & & & & & & & \\
\hline $\begin{array}{l}\text { Cadmium } \\
(\mathrm{mg} / \mathrm{L})\end{array}$ & & & 0.0021 & & & & 2.71 & & 0.54 & & & & & & & \\
\hline Zinc (mg/L) & 0.25 & & 2.3 & & & & 1.89 & & 7.51 & & & & & & & \\
\hline Salinity (g/L) & 4 & & & & & & 2.10 & & 17.25 & & 21.8 & & & & & \\
\hline $\begin{array}{l}\text { Total dissolved } \\
\text { solid }(\mathrm{mg} / \mathrm{L})\end{array}$ & 2848 & & & & 14916 & & & 28800 & & & & & & & & \\
\hline Turbidity & & 530 & & & & & & & 213 & 103 & & & & 1982.6 & & \\
\hline References & $\begin{array}{l}\text { (Aziz, } \\
\text { Aziz, } \\
\text { Yusoff, } \\
\text { et al., } \\
2011)\end{array}$ & $\begin{array}{c}\text { (N. } \\
\text { Laitinen, A. } \\
\text { Luonsi, \& } \\
\text { J. Vilen, } \\
\text { 2006) }\end{array}$ & $\begin{array}{l}\text { (Wu et } \\
\text { al., } \\
\text { 2011) }\end{array}$ & $\begin{array}{l}\text { (Miao } \\
\text { et al., } \\
2016)\end{array}$ & $\begin{array}{l}\text { (Y. J. } \\
\text { Wei, Ji, } \\
\text { Li, \& } \\
\text { Qin, } \\
\text { 2012) }\end{array}$ & $\begin{array}{l}\text { (Nhat } \\
\text { et al., } \\
2017 \text { ) }\end{array}$ & $\begin{array}{l}\text { (Mojiri } \\
\text { et al., } \\
\text { 2014) }\end{array}$ & $\begin{array}{l}\text { (Bu et } \\
\text { al., } \\
2010)\end{array}$ & $\begin{array}{l}\text { (Yong } \\
\text { et al., } \\
2018 \text { ) }\end{array}$ & $\begin{array}{l}\text { (Tsilogeorgis } \\
\text { et al., 2008) }\end{array}$ & $\begin{array}{l}\text { (Trabelsi } \\
\text { et al., } \\
2013)\end{array}$ & $\begin{array}{l}\text { (Miao } \\
\text { et al., } \\
2014 \text { ) }\end{array}$ & $\begin{array}{l}\text { (Spagni } \\
\& \\
\text { Marsili- } \\
\text { Libelli, } \\
\text { 2009) }\end{array}$ & $\begin{array}{l}\text { (Pirsaheb } \\
\text { et al., } \\
2017)\end{array}$ & $\begin{array}{l}\text { (Chu } \\
\text { et al., } \\
2008)\end{array}$ & $\begin{array}{c}\text { (Yin, } \\
\text { Wang, } \\
\text { Xu, } \\
\text { Wu, \& } \\
\text { Zhao, } \\
\text { 2018) }\end{array}$ \\
\hline
\end{tabular}


Table 1 (continued)

\begin{tabular}{|c|c|c|c|c|c|c|c|c|c|c|c|c|c|c|c|c|}
\hline Parameter (unit) & \multicolumn{16}{|c|}{ Leachate characteristics } \\
\hline $\mathrm{pH}$ & 9.5 & 7.34 & 8.05 & 8.98 & 8.0 & 8.55 & 7.1 & 8.4 & 7.5 & 7.5 & 7.8 & 7.6 & 8.5 & 8.4 & 8.33 & 8.5 \\
\hline Phenol (mg/L) & & & & 185.67 & & & & & & & & & & & & \\
\hline Colour (Pt.Co) & 64 & 2113 & & & & & & & & & & & & & & \\
\hline Electrical conductivity $(\mathrm{ms} / \mathrm{cm})$ & 13750 & & 14.2 & & & & & 9.5 & & 41.1 & 8.9 & 14000 & & & 5.41 & 11.3 \\
\hline Suspended solids (mg/L) & & & 0.25 & 4.87 & & & & & 2050 & 2000 & 6400 & 100 & 730 & & 80 & \\
\hline Alkalinity $(\mathrm{mg} / \mathrm{L})$ & & & 119 & & & & & & 16700 & & & & 123000 & & & 2028 \\
\hline $\mathrm{BOD}_{5}(\mathrm{mg} / \mathrm{L})$ & 38 & 285 & 301 & 12.55 & 301 & 243 & 444 & & 38200 & 11500 & 70 & 150 & 530 & 39 & 7100 & 197 \\
\hline $\mathrm{COD}(\mathrm{mg} / \mathrm{L})$ & 538 & 3018 & 1759 & 2510 & 1615 & 2495 & 1047 & 9058 & 48000 & 30500 & 4000 & 2786 & 4500 & 2508 & 10500 & 2408 \\
\hline $\mathrm{BOD}_{5} / \mathrm{COD}$ & 0.07 & 0.09 & & & & & 0.42 & & & & & & & & & \\
\hline Ammonia-N (mg/L) & 6.10 & 49 & & & 958 & 1680 & & 606 & & & 290 & 800 & 990 & 1087 & 461 & 271 \\
\hline Total Nitrogen & & & & & & 1808 & & & & 8050 & & & & & & 414 \\
\hline TKN (mg/L) & & & 1191 & & 1082 & & 89.9 & & & & & & 1100 & & & \\
\hline TOC (mg/L) & 297 & 51.39 & & & & & & & & 2100 & & & & & & \\
\hline Nitrite-N (mg/L) & & & & 0.04 & & 0.10 & & & & & & & 67 & & & \\
\hline Nitrate-N (mg/L) & & & & 2.93 & & 2.73 & & 35 & & 17 & 22 & 6 & 28 & & & 15.1 \\
\hline Total Phosphorus (mg/L) & & & 5.7 & & & & 18.4 & 250 & & 27.5 & & & 16.7 & & & \\
\hline Magnesium (mg/L) & & & & & & & & & & & & 190 & & & & \\
\hline Nickel (mg/L) & & 29.67 & & & & & & & & & & & & & 3.18 & \\
\hline Calcium (mg/L) & & & & & & & & & & & & 110 & & & & \\
\hline Chromium (mg/L) & & & & & & & & & & & & 1.5 & & & & \\
\hline Chloride (mg/L) & & 1280 & & & & 1677 & & & & & & 2200 & 3200 & 3091 & & \\
\hline Copper (mg/L) & & & & & & & & & & & & 0.48 & & & & \\
\hline Sulfate (mg/L) & & & & & & & & & & 500 & 70 & & & & & \\
\hline Phosphate (mg/L) & & & 4.6 & 154.44 & & & & & 48 & & 51 & & 26 & 4.8 & 2.08 & 7.8 \\
\hline Barium (mg/L) & & & & & & & & & & & & 1.8 & & & & \\
\hline Total Iron $(\mathrm{mg} / \mathrm{L})$ & & & & & & & & & & & & 3 & & & & \\
\hline Lead (mg/L) & & & & & & & & & & & & 0.03 & & & & \\
\hline Zinc (mg/L) & & & & & & & & & & & & 3.7 & & & 7.01 & \\
\hline Total dissolved solid (mg/L) & & & & & & & & & & & 6700 & & & & 2620 & \\
\hline Turbidity & & & & & & & & & & 1300 & & & & & & 103 \\
\hline References & $\begin{array}{l}\text { (Ying, } \\
\text { Xu, et } \\
\text { al., } \\
2012 \text { ) }\end{array}$ & $\begin{array}{l}\text { (Moji } \\
\text { ri et } \\
\text { al., } \\
2017)\end{array}$ & $\begin{array}{l}\text { (Spa } \\
\text { gni } \\
\text { et } \\
\text { al., } \\
2008 \\
\text { ) }\end{array}$ & $\begin{array}{l}\text { (Micha } \\
\text { lska et } \\
\text { al., } \\
\text { 2019) }\end{array}$ & $\begin{array}{c}\text { (Marsili } \\
\text {-Libelli, } \\
\text { Spagni, } \\
\text { \& } \\
\text { Susini, } \\
\text { 2008) }\end{array}$ & $\begin{array}{c}\text { (D. B. } \\
\text { Zhang, } \\
\text { Wu, } \\
\text { Wang, \& } \\
\text { Zhang, } \\
\text { 2014) }\end{array}$ & $\begin{array}{c}\text { (Fongsati } \\
\text { tkul, } \\
\text { Wareha } \\
\text { m, \& } \\
\text { Elefsinio } \\
\text { tis, 2008) }\end{array}$ & $\begin{array}{c}\text { (Capod } \\
\text { ici, Di } \\
\text { Trapan } \\
\text { i, \& } \\
\text { Vivian } \\
\text { i, } \\
\text { 2014) }\end{array}$ & $\begin{array}{l}\text { (Mou } \\
\text { savi } \\
\text { et al., } \\
\text { 2015) }\end{array}$ & $\begin{array}{l}\text { (Yari } \\
\text { mtepe } \\
\& \text { Oz, } \\
2018 \text { ) }\end{array}$ & $\begin{array}{c}\text { (Ran } \\
\text { jan } \\
\text { et } \\
\text { al., } \\
2016 \\
\text { ) }\end{array}$ & $\begin{array}{c}\text { (Nara } \\
\text { yan et } \\
\text { al., } \\
2019)\end{array}$ & $\begin{array}{c}\text { (Grosse } \\
\text { r et al., } \\
2019)\end{array}$ & $\begin{array}{l}\text { (Tan } \\
\text { et al., } \\
2016)\end{array}$ & $\begin{array}{c}\text { (Ganj } \\
\text { ian et } \\
\text { al., } \\
2018)\end{array}$ & $\begin{array}{c}\text { (Shariat } \\
\text { i, } \\
\text { Bonakd } \\
\text { arpour, } \\
\text { Zare, \& } \\
\text { Ashtiani } \\
\text {, 2011) }\end{array}$ \\
\hline
\end{tabular}


Table 2. Leachate standard discharge limits of different regions

\begin{tabular}{|c|c|c|c|c|c|c|c|}
\hline \multirow[t]{2}{*}{ Parameter (units) } & \multicolumn{7}{|c|}{ Standards } \\
\hline & $\mathrm{EQR}^{\mathrm{a}}$ & $\mathrm{CDS}^{\mathrm{b}}$ & $\mathrm{EPA}^{\mathrm{c}}$ & $\mathrm{AGSS}^{\mathrm{d}}$ & SESCA $^{\mathrm{e}}$ & HWLG $^{f}$ & $\mathrm{GS}^{\mathrm{g}}$ \\
\hline$\overline{\mathrm{pH}}$ & $6-9$ & & & $6.5-9$ & $5.5-9$ & $6.5-8.5$ & \\
\hline Temperature $\left({ }^{\circ} \mathrm{C}\right)$ & 40 & & & & & 32 & \\
\hline Phenol (mg/L) & 0.001 & & & & & 0.2 & \\
\hline Colour (Pt.Co) & 100 & 40 & & & & & \\
\hline Turbidity (NTU) & & & & 20 & & & \\
\hline Suspended solids (mg/L) & 50 & & & 20 & 30 & 20 & \\
\hline $\mathrm{BOD}_{5}(\mathrm{mg} / \mathrm{L})$ & 20 & 30 & & 10 & 20 & 20 & 50 \\
\hline COD (mg/L) & 400 & 100 & & & 120 & & 200 \\
\hline $\mathrm{BOD}_{5} / \mathrm{COD}$ & 0.05 & & & & & & \\
\hline Ammonia-N (mg/L) & 5 & 40 & & & & & \\
\hline Nitrite-N (mg/L) & & 25 & & & & & 2 \\
\hline Nitrate-N (mg/L) & & & & 0.5 & & 2 & \\
\hline Total Nitrogen (mg/L) & & & & & & & 70 \\
\hline TKN (mg/L) & & & & & 100 & & \\
\hline Phosphorus (mg/L) & & 3 & & 0.5 & & & 3 \\
\hline Total Organic Carbon (mg/L) & & & & & & & 10 \\
\hline Manganese (mg/L) & 0.20 & & & & 5 & 0.5 & \\
\hline Mercury (mg/L) & & & & 0.0001 & 0.001 & & 0.05 \\
\hline Chromium (mg/L) & 0.20 & 0.05 & 0.05 & 0.0044 & & 0.5 & 0.5 \\
\hline Cadmium (mg/L) & 0.01 & 0.01 & 0.01 & 0.002 & 0.03 & 0.05 & 0.1 \\
\hline Lead $(\mathrm{mg} / \mathrm{L})$ & 0.1 & 0.1 & 0.03 & 0.005 & 0.2 & 0.1 & 0.5 \\
\hline Arsenic (mg/L) & 0.05 & & & 0.05 & & 0.1 & \\
\hline Barium (mg/L) & 1.00 & & & & & 1.0 & \\
\hline Sulfide (mg/L) & 0.5 & & & & & & 1 \\
\hline Silver (mg/L) & 0.10 & & 0.05 & 0.0001 & & & \\
\hline Selenium (mg/L) & 0.02 & & & 0.005 & & 0.05 & \\
\hline Nickel (mg/L) & 0.20 & 0.1 & 0.013 & 0.15 & 1.0 & 0.5 & 1 \\
\hline Copper (mg/L) & 0.20 & & 0.07 & 0.01 & 2 & 0.1 & 0.5 \\
\hline Iron $(\mathrm{mg} / \mathrm{L})$ & 5 & & & 1 & & & \\
\hline Zinc (mg/L) & 2 & & 0.3 & 0.05 & 5 & 0.2 & 2 \\
\hline Total dissolved solid (\%) & & & & & 3000 & & \\
\hline Zeta potential (ORP) (mV) & -14.9 & & & & & & \\
\hline
\end{tabular}

EOR: Environmental Quality (Control of Pollution from Solid Waste Transfer Station and Landfill) Regulations 2009, under the Laws of Malaysia-Malaysia Environmental Quality Act 1974 (Aziz, Aziz, et al., 2011a, 2011b; Aziz, Aziz, Yusoff, et al., 2011; Aziz et al., 2012; Mojiri et al., 2014; Yong et al., 2018)

CDS: Chinese Discharge Standards, 2008. Standard for Pollution Control on the Landfill Site of Municipal Solid Waste. GB16889-2008 (Mojiri et al., 2017; Wu et al., 2011; Ying, Peng, et al., 2012; Ying, Xu, et al., 2012).

EPA: Environmental Protection Agency (EPA), USA, EPA Economic. Analysis of Final Effluent Limitations Guidelines and Standards for the Landfills Point Source Category, 2005 (Kurniawan, Lo, \& Chan, 2006)

AGSS: Australian guidelines for sewerage systems — effluent management (ARMCANZ, 1997)

SESCA: Standard of Effluent Standard for Coastal Aquaculture from Ministry of Natural Resources and Environment (2004), Thailand (Jitthaisong, Dhanmanonda, Chunkao, \& Teejuntuk, 2012)

HWLG: Hazardous waste legislation guide. Ministry of Environment, British Columbia (Kamaruddin et al., 2017) GS: German standards (51. Anhang Rahmen-Abwasser, Anonymus 1996) (Stegmann, Heyer, \& Cossu, 2005) 


\subsection{Treatment of Landfill leachate}

Landfill leachate treatment technologies with low cost and improved efficiency are important for sewage treatment (Yin et al., 2018). Leachate treatment is considered a worldwide problem as it affects most countries. The basic difficulty in leachate treatment is the selection of combined reasonable, economical, and efficient processes and technologies. In addition, the major challenges associated with developing leachate treatment processes are the TN removal rate improvement and total cost reduction (K. Wang, $\mathrm{Li}, \mathrm{Tan}, \& \mathrm{Wu}, 2018)$. Treatment prior to discharge is a legal necessity to avoid environmental contamination (Aziz, Aziz, et al., 2011a). However, the treatment of highstrength organic content, complex chemical composition and seasonally diverse volume of leachate owing to rainwater ingress into the landfill is often complicated (Aluko \& Sridhar, 2013; Fongsatitkul et al., 2008). Low biodegradability and C:N ratio of landfill leachate poses high challenges for treatment (Miao et al., 2014). At present, there is no single unit process available for proper leachate treatment as conventional wastewater treatment processes cannot achieve a satisfactory level for degrading toxic substances present (Bu et al., 2010; D. B. Zhang et al., 2014). Therefore, there is a growing interest in examination of different leachate treatment processes for maximum operational flexibility (Yarimtepe \& Oz, 2018). Based on leachate characteristics, discharge requirements, technical possibilities, regulatory requirements and financial considerations, several techniques have been adopted for degrading this highly diverse organic effluent, presenting varying degree of efficiency (El-Fadel et al., 2013; Fudala-Ksiazek et al., 2014; Neczaj et al., 2008; Remmas et al., 2018). These techniques do consider landfill leachate age classification as a guide for selecting suitable treatment for a particular leachate (Yong et al., 2018). Recently, leachate treatment plants combine one or more treatment strategies for biodegradable and non-biodegradable substances present (Contrera et al., 2014; Neczaj et al., 2005; Spagni \& Marsili-Libelli, 2009).

Fig. 1 summarizes the evolution of main published works on landfill leachate treatment. Data extracted from Web of Science core-collection over 2005-2020. The search was made by Topic using "Leachate treatment" as the keyword. It is evident that in the past few decades, leachate treatment received significant attention as the number of articles exponentially increases. This could be attributed to environmental effect of leachate resulting from massive solid waste generation.

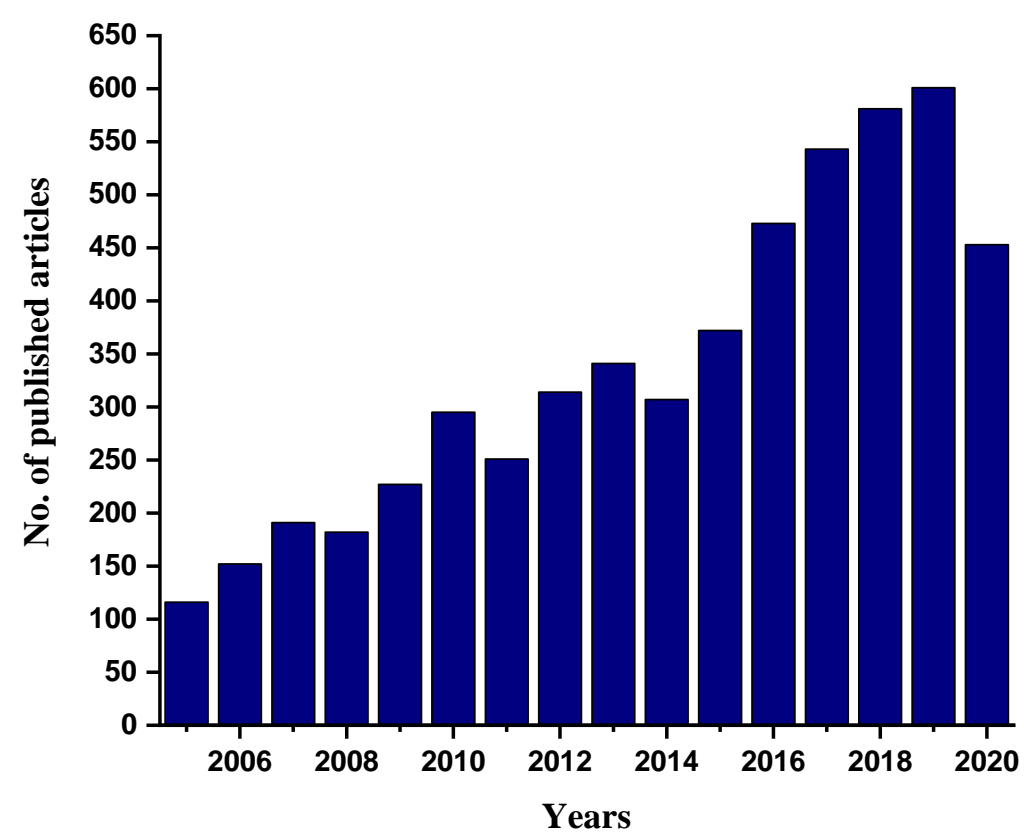

Fig. 1. Graphical representation for the evolution of publications on leachate treatment since 2005 (Source: Web of science core collection)

\subsection{Approaches for leachate treatment}

In order to increase performance efficiency and meet the industrial effluent discharge stringent regulatory requirements (Vukovic, Cosic, Kucic, Kopcic, \& Briski, 2012), several factors are taken into account before determining which treatment method and material should be applied at a specific landfill based on their merits and 
demerits, and also considering the landfill age as highlighted in Tables 3,4 and 5. and . The key factor is the treatment cost which varies among methods and even within each method depending on the composition of landfill leachate and local environmental regulations. Other significant factors include land and operating cost (Dogaris, Ammar, Philippidis, \& Biotechnology, 2020). The existing methods of leachate recovery, reuse and degradation can be principally grouped into: (i) biodegradation (via aerobic and/or anaerobic processes); (ii) physicochemical method, (iii) a combination of (i and ii), (iv) Leachate transfer [co-treatment of leachate with other wastewaters (Municipal/domestic wastewater treatment plants) and Recycling] (v) other potential alternatives available (Capodici et al., 2014; Contrera et al., 2014; Mojiri et al., 2014). The integration of physicochemical and biological processes has the potential to synergize the benefits of each single process and has been reported to be effective in the treatment of stabilized landfill leachate (Wu et al., 2011).

\section{- Physicochemical processes}

Physicochemical processes are usually applied for the pre-treatment, post-treatment and advanced treatment of landfill leachate (Miao et al., 2015). They are suitable for the removal of refractory substances from stabilized leachate (Kurniawan et al., 2006). They can also be used for specific pollutant degradation (Renou, Givaudan, Poulain, Dirassouyan, \& Moulin, 2008). However, they are costly, generate secondary pollution coupled with lower effectiveness and reliability (Tsilogeorgis et al., 2008; Yin et al., 2018). They also possess lower effectiveness and less reliability. The common physicochemical processes are highlighted in Fig. 2.

\section{- Biological methods}

The traditional nitrification-denitrification (Biological) processes are used as the major landfill leachate treatment techniques. However, the utilization of organic substances in aerobic processes results to severe carbon supply shortage for the subsequent anoxic denitrification (Miao et al., 2015). Biological treatment has sub-divisions as shown in Fig. 2. Anaerobic systems offer advantages such as: high organic loading rates capacity; methane production; low sludge generation and the capability of retaining microbes with special functions (Miao et al., 2016). Several studies proved the biological treatment processes based on suspended-growth biomass, exhibit satisfactory and consistent performance in terms of organic carbon and nutrients removal due to their simplicity and cost-effectiveness (Aziz et al., 2012; Contrera et al., 2014; Luo et al., 2020; Mojiri et al., 2014; Ranjan et al., 2016; Yin et al., 2018). Thus, providing enough hydraulic residence time. Other available landfill leachate treatment options include leachate recirculation through the landfill, spray irrigation on abutting grassland, on-site treatment, re-injection, leachate evaporation using evaporation ponds and landfill-generated methane as fuel or a combination (Neczaj et al., 2008; Ranjan et al., 2016). Therefore, to comply with the strict regulation of nitrogen release and potential effect of recalcitrant leachate components during biological treatment stage, an increasing demand exists for advanced studies on leachate treatment and disposal. 


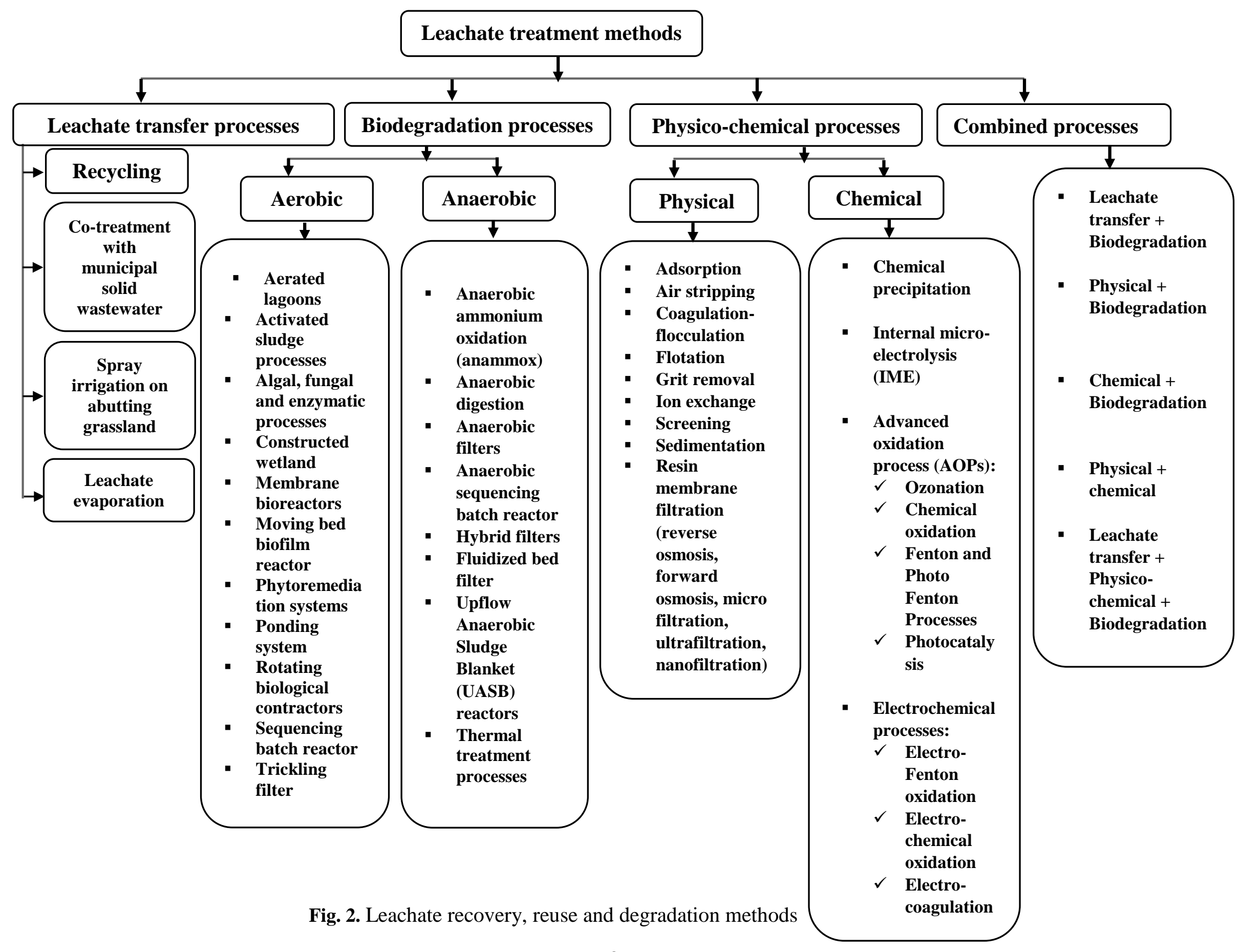


Table 3. Various leachate treatment methods with merits and demerits

\begin{tabular}{|c|c|c|c|c|}
\hline Method & Focused pollutants & 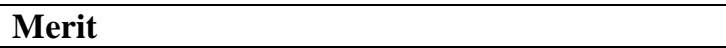 & Demerit & Ref. \\
\hline \multicolumn{5}{|l|}{ Leachate transfer } \\
\hline Co-treatment with sewage & $\begin{array}{l}\mathrm{BOD}, \mathrm{COD}, \mathrm{NH}_{4}{ }^{+}-\mathrm{N} \\
\text { suspended solids, }\end{array}$ & $\begin{array}{l}\text { Feasible, convenient, easy maintenance and } \\
\text { cost-effective alternative } \\
\text { - Increases the BOD/COD ratio and rendering } \\
\text { wastewater suitable for biological treatment. } \\
\text { - Nitrogen and phosphate present in leachate and } \\
\text { sewage complement each other during the } \\
\text { treatment process }\end{array}$ & $\begin{array}{l}\text { Suppression of microorganisms breaking down by } \\
\text { heavy metals and refractory compounds in activated } \\
\text { sludge process } \\
\text { - Some recalcitrant organic compounds (humic acids, } \\
\text { fulvic acids and hydrophilics) in leachate can escape } \\
\text { this process. Thus, lower the UV transmittance of waste } \\
\text { streams, and interfere with the associated disinfection } \\
\text { efficacy } \\
\text { - Lack of sufficient alkalinity for nitrification process } \\
\text { - Increased production of sludge in urban wastewater } \\
\text { treatment facilities because of extra organic leachate } \\
\text { load }\end{array}$ & $\begin{array}{l}\text { (Trabelsi et } \\
\text { al., 2013) } \\
\text { (Ranjan et al., } \\
\text { 2016) } \\
\text { (Grosser et } \\
\text { al., 2019) } \\
\text { (Dogaris et } \\
\text { al., 2020) } \\
\text { (Luo et al., } \\
\text { 2020) } \\
\text { (Kamaruddin } \\
\text { et al., 2017) } \\
\text { (Dereli, } \\
\text { Clifford, } \\
\text { Casey, \& } \\
\text { Technology, } \\
\text { 2020) }\end{array}$ \\
\hline Spray irrigation & & $\begin{array}{l}\text { Effective technology for polishing dilute, high- } \\
\text { volume leachate and for pretreated leachate }\end{array}$ & $\begin{array}{l}\text { - Lack of accessible large vegetation area near landfill } \\
\text { site } \\
\text { - Volatilize contaminants and generate of aerosols } \\
\text { - Endanger leaf, plant attrition and restricted ability to } \\
\text { reduce organics. }\end{array}$ & $\begin{array}{l}\text { (Schiopu \& } \\
\text { Gavrilescu, } \\
\text { 2010) }\end{array}$ \\
\hline Recycling & COD, BOD & $\begin{array}{l}\text { - Increases the moisture content above their } \\
\text { field capacity and provides nutrient and } \\
\text { enzyme transfer between the methanogens and } \\
\text { the liquids/solids } \\
\text { - Improves leachate standard } \\
\text { - Shortens stabilization period } \\
\text { - Reduce leachate volume } \\
\text { - Simple operation, pH buffering, and } \\
\text { inexpensive }\end{array}$ & $\begin{array}{l}\text { - It can amount to a methanogenesis inhibition } \\
\text { - High volume of recirculated leachate can give rise to } \\
\text { ponding, saturation and acidification which will affect } \\
\text { solid wastes degradation by anaerobic conditions } \\
\text { - It is neither effective nor economically attractive } \\
\text { - Increases leachate toxicity }\end{array}$ & $\begin{array}{l}\text { (Renou et al., } \\
\text { 2008) } \\
\text { (Kamaruddin } \\
\text { et al., 2017) } \\
\text { (Schiopu \& } \\
\text { Gavrilescu, } \\
\text { 2010) } \\
\text { (Kurniawan, } \\
\text { Lo, Chan, \& } \\
\text { Sillanpää, } \\
\text { 2010) } \\
\text { (Dogaris et } \\
\text { al., 2020) } \\
\text { (J. Gao et al., } \\
\text { 2015) }\end{array}$ \\
\hline Evaporation & & $\begin{array}{l}\text { Produces good quality and simple to dispose of } \\
\text { effluents with small fraction of the original } \\
\text { leachate volume as concentrated residuals } \\
\text { volume. }\end{array}$ & $\begin{array}{l}\text { Faced with odor, gas aggregation, process operation } \\
\text { and maintenance related operational problems }\end{array}$ & $\begin{array}{l}\text { (Schiopu \& } \\
\text { Gavrilescu, } \\
\text { 2010) }\end{array}$ \\
\hline
\end{tabular}




\begin{tabular}{|c|c|c|c|c|}
\hline $\begin{array}{l}\text { Combined treatment } \\
\text { technologies }\end{array}$ & & & & \\
\hline $\begin{array}{l}\text { Combined treatment } \\
\text { technologies }\end{array}$ & $\begin{array}{l}\text { Recalcitrant } \\
\text { compounds, heavy } \\
\text { metals, ammonia, } \\
\text { organic and inorganic } \\
\text { matter from landfill } \\
\text { leachate }\end{array}$ & $\begin{array}{l}\text { Capacity to hybridize the merits of different } \\
\text { treatment options, while addressing their } \\
\text { respective constraints } \\
\text { Activated sludge bioregeneration, } \\
\text { microorganism's protection from organic } \\
\text { loading shocks and bacteria washout protection, } \\
\text { increased settling and drainability of the sludge }\end{array}$ & $\begin{array}{l}\text { - High energy consumption resulting to high operational } \\
\text { costs } \\
\text { - Handling charges for disposal of sludge }\end{array}$ & $\begin{array}{l}\text { (Kurniawan et } \\
\text { al., 2006) } \\
\text { (Pirsaheb et } \\
\text { al., 2017) } \\
\text { (Tripathy \& } \\
\text { Kumar, 2017) }\end{array}$ \\
\hline \multicolumn{5}{|l|}{ Chemical methods } \\
\hline Chemical precipitation & $\begin{array}{l}\mathrm{NH}_{3}-\mathrm{N}, \mathrm{NH}_{4}{ }^{+}-\mathrm{N} \text {, } \\
\text { heavy metals, and non- } \\
\text { biodegradable organic } \\
\text { compounds }\end{array}$ & $\begin{array}{l}\text { - Good capability and process simplicity } \\
\text { - Utilizes less expensive equipment's resulting in } \\
\text { low capital cost }\end{array}$ & $\begin{array}{l}\text { - Large amount of chemicals and high dose of precipitant } \\
\text { required with low COD removal efficiency } \\
\text { - Sensitivity of the process to } \mathrm{pH} \\
\text { - Large sludge generation that require further disposal } \\
\text { - Efficiency controlled by molar ratio of } \mathrm{PO}_{4}^{3-}, \mathrm{Mg} \text { and } \\
\mathrm{NH}_{4}{ }^{+}\end{array}$ & $\begin{array}{l}\text { (Narayan et } \\
\text { al., 2019) } \\
\text { (Kamaruddin } \\
\text { et al., 2017) } \\
\text { (Renou et al., } \\
\text { 2008) }\end{array}$ \\
\hline Chemical oxidation & $\begin{array}{l}\text { Non-biodegradable, } \\
\text { soluble organic, and/or } \\
\text { toxic substances }\end{array}$ & $\begin{array}{l}\text { Organic substances present in leachate are } \\
\text { oxidized to the highest stable state of oxidation }\end{array}$ & $\begin{array}{l}\text { - The broad spectrum of pollutants present is unlikely to } \\
\text { be thoroughly handled } \\
\text { - High oxidant doses, investment cost and electrical } \\
\text { energy required alongside generation of excess sludge }\end{array}$ & $\begin{array}{l}\text { (Luo et al., } \\
2020) \\
\text { (Dogaris et } \\
\text { al., 2020) } \\
\text { (J. Gao et al., } \\
\text { 2015) }\end{array}$ \\
\hline $\begin{array}{l}\text { Advanced oxidation } \\
\text { processes (AOPs) }\end{array}$ & $\begin{array}{l}\text { Non-biodegradable } \\
\text { and/or toxic organic } \\
\text { compounds }\end{array}$ & $\begin{array}{l}\text { - One-pot technology that operates at ambient } \\
\text { temperature and pressure } \\
\text { - An effective method for recalcitrant organic } \\
\text { mineralisation in leachate }\end{array}$ & $\begin{array}{l}\text { - Treatability frequently degraded by the chlorine } \\
\text { oxidation potentials } \\
\text { - Economically not acceptable for large-scale effluents } \\
\text { - High oxidant doses, investment cost and electrical } \\
\text { energy required alongside generation of excess sludge }\end{array}$ & $\begin{array}{l}\text { (Chu et al., } \\
2008 \text { ) } \\
\text { (Foo \& } \\
\text { Hameed, } \\
\text { 2009) } \\
\text { (Gautam, } \\
\text { Kumar, \& } \\
\text { Lokhandwala, } \\
\text { 2019) } \\
\text { (J. Gao et al., } \\
\text { 2015) } \\
\text { (Renou et al., } \\
\text { 2008) }\end{array}$ \\
\hline Fenton process & Organic constituents & $\begin{array}{l}\text { - Manifests much faster kinetics than biological } \\
\text { treatment } \\
\text { - Successfully used to mineralize a large variety of } \\
\text { organic components in leachate }\end{array}$ & $\begin{array}{l}\text { Embroidered by the final iron sludge output requiring } \\
\text { ultimate disposal } \\
\text { - Safety and operational hazards associated with high } \\
\text { acid requirements } \\
\text { - Incures high treatment cost }\end{array}$ & $\begin{array}{l}\text { (Luo et al., } \\
2020 \text { ) }\end{array}$ \\
\hline
\end{tabular}




\begin{tabular}{|c|c|c|c|c|}
\hline & & & & $\begin{array}{l}\text { (Umar, Aziz, } \\
\text { \& Yusoff, } \\
\text { 2010) }\end{array}$ \\
\hline Electrochemical-oxidation & $\begin{array}{l}\text { Colour, organic } \\
\text { contaminants, BOD } \\
\text { and COD, ammonia } \\
\text { nitrogen }\end{array}$ & $\begin{array}{l}\text { - Ease of operation and environmental } \\
\text { compatibility } \\
\text { - Versatility and amenability of automation } \\
\text { - Mineralizes organics into } \mathrm{CO}_{2} \text { and water } \\
\text { - Effective for disintegrating non-biodegradable } \\
\text { contaminants } \\
\text { - Offers high efficiency with no sludge production } \\
\text { - Enhance the biodegradability index (BOD/COD) }\end{array}$ & $\begin{array}{l}\text { - High energy consumption } \\
\text { - High operating costs } \\
\text { Probable formation of chlorinated organic compounds }\end{array}$ & $\begin{array}{l}\text { (Chu et al., } \\
\text { 2008) } \\
\text { (A. } \\
\text { Fernandes, } \\
\text { Pacheco, } \\
\text { Ciríaco, \& } \\
\text { Lopes, 2015) } \\
\text { (Kamaruddin } \\
\text { et al., 2017) } \\
\text { (J. Gao et al., } \\
\text { 2015) } \\
\text { (Mandal, } \\
\text { Dubey, \& } \\
\text { Gupta, 2017) }\end{array}$ \\
\hline Electro-Fenton processes & $\begin{array}{l}\text { Organic matter; } \\
\text { ammonia nitrogen }\end{array}$ & $\begin{array}{l}\text { - Feasible for treatment of leachates with } \\
\text { extremely high organic load content }\end{array}$ & $\begin{array}{l}\text { - Incurs higher energy and infrastructure costs associated } \\
\text { with the use of electricity and UV light }\end{array}$ & $\begin{array}{l}\text { (Luo et al., } \\
\text { 2020) (Umar } \\
\text { et al., 2010) }\end{array}$ \\
\hline Electro-coagulation & COD, TSS, phosphorus & $\begin{array}{l}\text { - Low operating and maintenance costs } \\
\text { - Promotes advanced flocculation process } \\
\text { - Less sludge of better quality, hydrophobic solid } \\
\text { content produced with no chemical addition }\end{array}$ & $\begin{array}{l}\text { Electrode passivation } \\
\text { - Formation of undesirable toxic chlorinated by-products } \\
\text { and impermeable oxide film } \\
\text { - Energy intensive }\end{array}$ & $\begin{array}{l}\text { (Gautam et } \\
\text { al., 2019) } \\
\text { (Roy et al., } \\
\text { 2018) } \\
\text { (A. Fernandes } \\
\text { et al., 2015) }\end{array}$ \\
\hline \multicolumn{5}{|l|}{ Physical methods } \\
\hline Coagulation-flocculation & $\begin{array}{l}\text { Non-biodegradable } \\
\text { organic matter, clays, } \\
\text { colloids, suspended } \\
\text { solids, surfactants, } \\
\text { heavy metals and acids }\end{array}$ & $\begin{array}{l}\text { - Characterized by ease of use and substantial } \\
\text { reduction of organic load } \\
\text { - Simple and low cost }\end{array}$ & $\begin{array}{l}\text { - High cost of coagulants } \\
\text { - Sensitivity to pH and limited COD removal } \\
\text { - High sludge productions leading to secondary pollution } \\
\text { Increased concentration of aluminum/iron, may be } \\
\text { observed }\end{array}$ & $\begin{array}{l}\text { (Miao et al., } \\
2016 \text { ) } \\
\text { (Khoo et al., } \\
2020 \text { ) } \\
\text { (Trabelsi et } \\
\text { al., 2013) } \\
\text { (Roy et al., } \\
\text { 2018) } \\
\text { (Kamaruddin } \\
\text { et al., 2017) }\end{array}$ \\
\hline Adsorption & $\begin{array}{l}\text { Organic and inorganic } \\
\text { pollutants, recalcitrant } \\
\text { organic compounds, } \\
\text { heavy metals }\end{array}$ & $\begin{array}{l}\text { - Efficient, promising and polishing technique } \\
\text { - Exhibits superior properties of surface reactivity } \\
\text { larger surface area, microporous structure, high } \\
\text { adsorption capacity and better thermal stability }\end{array}$ & $\begin{array}{l}\text { High cost of granular/powdered activated carbon } \\
\text { Require regeneration of activated carbon at regular } \\
\text { intervals } \\
\text { - Cannot be used as the sole treatment method for } \\
\text { leachate }\end{array}$ & $\begin{array}{l}\text { (Nawaz et al., } \\
2020) \\
\text { (Omar, } \\
\text { Rohani, \& }\end{array}$ \\
\hline
\end{tabular}




\begin{tabular}{|c|c|c|c|c|}
\hline & & & - Possible carbon fouling & $\begin{array}{l}\text { Engineering, } \\
\text { 2015) } \\
\text { (Kamaruddin, } \\
\text { Yusoff, Aziz, } \\
\text { \& Hung, } \\
\text { 2015) } \\
\text { (Bu et al., } \\
\text { 2010) } \\
\end{array}$ \\
\hline $\begin{aligned} & \text { Air stripping } \\
& \quad> \text { Ammonia } \\
& \text { stripping } \\
&>\quad \text { Methane } \\
& \text { stripping }\end{aligned}$ & $\begin{array}{l}\text { Methane, ammonium } \\
\mathrm{NH}_{3}-\mathrm{N} \text {, and volatile } \\
\text { organic compounds } \\
\text { (VOCs) }\end{array}$ & $\begin{array}{l}\text { - Process efficiency significantly increases by } \\
\text { increasing pH, temperature, and retention time } \\
\text { - Ammonium stripping is economically appealing }\end{array}$ & $\begin{array}{l}\text { - Solving foaming problems require large stripping tower } \\
\text { - Stripping tower requires calcium carbonate scaling } \\
\text { - Additional ammonia control required for exiting air }\end{array}$ & $\begin{array}{l}\text { (Nawaz et al., } \\
2020 \text { ) } \\
\text { (Narayan et } \\
\text { al., 2019) } \\
\text { (Dogaris et } \\
\text { al., 2020) } \\
\text { (Kurniawan et } \\
\text { al., 2006) }\end{array}$ \\
\hline Ion exchange & $\begin{array}{l}\text { Heavy metals, } \mathrm{NH}_{4}^{+}, \\
\mathrm{NO}_{3}^{-} \text {, cations/anions, } \\
\text { dissolved compounds }\end{array}$ & $\begin{array}{l}\text { Nitrate and } \mathrm{NH}_{4}^{+} \text {ions concentrations can be } \\
\text { reduced to desired levels }\end{array}$ & $\begin{array}{l}\text { High operational cost } \\
\text { - } \text { Pre-treatment system is required } \\
\text { Require regeneration at regular intervals }\end{array}$ & $\begin{array}{l}\text { (Kurniawan et } \\
\text { al., 2006) } \\
\text { (Nawaz et al., } \\
\text { 2020) }\end{array}$ \\
\hline Flotation & $\begin{array}{l}\text { Oil and grease, humic } \\
\text { acid, colloids, ions, } \\
\text { macromolecules, } \\
\text { microorganisms and } \\
\text { fibers }\end{array}$ & & & $\begin{array}{l}\text { (Renou et al., } \\
\text { 2008) } \\
\text { (Kamaruddin } \\
\text { et al., 2017) } \\
\text { (J. Gao et al., } \\
\text { 2015) }\end{array}$ \\
\hline Membrane filtration: & $\begin{array}{l}\text { Suspended solids and } \\
\text { colloids }\end{array}$ & $\begin{array}{l}\text { - Low capital cost and ability to treat large } \\
\text { volumes } \\
\text { - Provide reliable separation } \\
\text { - Production of permeate with constant quality } \\
\text { - Commercial availability of a wide } \\
\text { variety of molecular weight cut-off membranes }\end{array}$ & $\begin{array}{l}\text { - Not suitable to be used alone } \\
\text { - } \text { pembrane fouling and high operating costs } \\
\text { - Filtration concenacities highly influenced by the molecular } \\
\text { weight of the membrane layers cut off and processed } \\
\text { materials }\end{array}$ & $\begin{array}{l}\text { Costa, Alfaia, } \\
\& \text { Campos, } \\
\text { 2019) } \\
\text { (Omar et al., } \\
\text { 2015) } \\
\text { (Luo et al., } \\
\text { 2020) } \\
\text { (J. Gao et al., } \\
\text { 2015) } \\
\text { (Roy et al., } \\
\text { 2018) }\end{array}$ \\
\hline Ultra-filtration (UF) & $\begin{array}{l}\text { High molecular weight } \\
\text { compounds }\end{array}$ & $\begin{array}{l}\text { - Can eradicate bulk molecular weight } \\
\text { compounds that appear to clog the membrane of } \\
\text { reverse osmosis } \\
\text { - High efficiency with low operating costs }\end{array}$ & $\begin{array}{l}\text { - Incomplete removal of polluting substances } \\
\text { - Reduced applicability due to fouling of the membrane }\end{array}$ & $\begin{array}{l}\text { (Abuabdou, } \\
\text { Ahmad, Aun, } \\
\text { \& Bashir, } \\
\text { 2020) } \\
\text { (Dabaghian, } \\
\text { Peyravi, } \\
\text { Jahanshahi, \& } \\
\text { Rad, 2018) }\end{array}$ \\
\hline
\end{tabular}




\begin{tabular}{|c|c|c|c|c|}
\hline & & & & $\begin{array}{l}\text { (Renou et al., } \\
\text { 2008) }\end{array}$ \\
\hline Nano-filtration (NF) & $\begin{array}{l}\text { Organic and inorganic } \\
\text { matter, heavy metals, } \\
\text { recalcitrant organic } \\
\text { compounds, sulphate } \\
\text { salts and hardness ions }\end{array}$ & $\begin{array}{l}\text { Offers a flexible approach to achieving various } \\
\text { goals in water quality }\end{array}$ & $\begin{array}{ll} & \text { Costly } \\
& \text { Needs less pressure than reverse osmosis }\end{array}$ & $\begin{array}{l}\text { (Dabaghian et } \\
\text { al., 2018) } \\
\text { (Renou et al., } \\
\text { 2008) }\end{array}$ \\
\hline Reverse osmosis (RO) & $\begin{array}{l}\text { Organic and inorganic } \\
\text { dissolved compounds, } \\
\text { heavy metals, } \\
\text { suspended and } \\
\text { dissolved solids }\end{array}$ & $\begin{array}{l}\text { It has high fluxes and functionality over broad } \\
\text { temperature and } \mathrm{pH} \text { range }\end{array}$ & $\begin{array}{l}\text { - Not economically appealing } \\
\text { - } \text { Extensive pretreatment is required before RO } \\
\text { - High-energy consumption } \\
\text { - Generation of large volume of concentrate }\end{array}$ & $\begin{array}{l}\text { (Luo et al., } \\
\text { 2020) (Renou } \\
\text { et al., 2008) } \\
\text { (Dabaghian et } \\
\text { al., 2018) } \\
\text { (Kurniawan et } \\
\text { al., 2006) }\end{array}$ \\
\hline \multicolumn{5}{|l|}{$\begin{array}{l}\text { Biodegradation } \\
\text { processes }\end{array}$} \\
\hline $\begin{array}{l}\text { Aerated lagoons/ } \\
\text { stabilization ponds }\end{array}$ & $\begin{array}{l}\text { Phenolic compounds } \\
\text { pathogens, organic and } \\
\text { inorganic matters }\end{array}$ & $\begin{array}{l}\text { - Quick start-up, simple and effective } \\
\text { - Low-cost operation \& maintenance } \\
\text { - Good ammonia nitrogen removal } \\
\text { concentrations }\end{array}$ & $\begin{array}{l}\text { - Micro-organisms susceptibility to ammonia toxicity } \\
\text { high pH and heavy metals with excessive algal growth } \\
\text { - Temperature dependence and offensive odors } \\
\text { - High energy consumption and longer aeration time } \\
\text { required } \\
\text { - Unsuitable for old sanitary landfill leachate }\end{array}$ & $\begin{array}{l}\text { (Nawaz et al., } \\
2020) \\
\text { (Renou et al., } \\
2008) \\
\text { (Costa et al., } \\
2019 \text { ) } \\
\text { (Kurniawan et } \\
\text { al., 2010) } \\
\text { (J. Gao et al., } \\
\text { 2015) }\end{array}$ \\
\hline $\begin{array}{l}\text { Activated sludge process } \\
\text { (ASP) }\end{array}$ & $\begin{array}{l}\text { Organic carbon, } \\
\text { nutrients, and ammonia }\end{array}$ & $\begin{array}{l}\text { - } \text { Most effective and economical process } \\
\text { - Adapted to any community size and to the } \\
\text { protection of sensitive receiving areas } \\
\text { - Generate slightly stabilized sludge } \\
\text { dephos to simultaneously introduce } \\
\text { dephatation }\end{array}$ & $\begin{array}{l}\text { - } \text { Excess sludge production and insufficient settleability } \\
\text { - Need for massive aeration } \\
\text { - } \text { Hegular capital costs and consequent energy consumption } \\
\text { - Bacterial inhibition and skilled personnel required } \\
\text { overloads }\end{array}$ & $\begin{array}{l}\text { (J. Gao et al., } \\
\text { 2015) } \\
\text { (Michalska et } \\
\text { al., 2019) } \\
\text { (Vukovic et } \\
\text { al., 2012) } \\
\text { (K. Wang et } \\
\text { al., 2018) } \\
\text { (Kurniawan et } \\
\text { al., 2010) }\end{array}$ \\
\hline Anaerobic digestion & $\begin{array}{l}\text { Organic and inorganic } \\
\text { matter }\end{array}$ & $\begin{array}{l}\text { - Low energy requirement } \\
\text { - Sow production of surplus sludge } \\
\text { - Small reaction volumes with high purification } \\
\text { - Biogas production and less phosphorus required }\end{array}$ & $\begin{array}{l}\text { - Could easily be influenced by changes in } \mathrm{pH} \text { and } \\
\text { temperature } \\
\text { - Smelly digestate and ammonia toxicity } \\
\text { - Digestion could be interfered by heavy metals }\end{array}$ & $\begin{array}{l}\text { (Wiszniowski, } \\
\text { Robert, } \\
\text { Surmacz- } \\
\text { Gorska, } \\
\text { Miksch, \& } \\
\text { Weber, 2006) } \\
\text { (Bove et al., } \\
\text { 2015) }\end{array}$ \\
\hline
\end{tabular}




\begin{tabular}{|c|c|c|c|c|}
\hline Anaerobic filter (AF) & & $\begin{array}{l}\text { - Less risk of fixed biomass washout } \\
\text { Biogas production with high substrate removal } \\
\text { rates at short HRTs and high OLRs }\end{array}$ & - Added cost of support media & $\begin{array}{l}\text { (Luo et al., } \\
2020) \\
\text { (Renou et al., } \\
\text { 2008) } \\
\text { (Kamaruddin } \\
\text { et al., 2017) } \\
\end{array}$ \\
\hline $\begin{array}{l}\text { Algae treatment } \\
\text { (phycoremediation) }\end{array}$ & & $\begin{array}{l}\text { Valorization of low-value waste matter and } \\
\text { wastewater } \\
\text { - Ecological, low-cost and carbon fixation } \\
\text { - Production of economically valuable biomass } \\
\text { - Sustainable nutrients and water source during } \\
\text { the manufacture of algal biofuels and } \\
\text { bioproducts }\end{array}$ & - High water and energy demand & $\begin{array}{l}\text { (Nawaz et al., } \\
\text { 2020) } \\
\text { (Dogaris et } \\
\text { al., 2020) }\end{array}$ \\
\hline Phytoremediation systems & & $\begin{array}{l}\text { Economical, effective and environmentally } \\
\text { friendly }\end{array}$ & & $\begin{array}{l}\text { (Luo et al., } \\
2020 \text { ) }\end{array}$ \\
\hline $\begin{array}{l}\text { Constructed wetland } \\
\text { (CW) }\end{array}$ & $\begin{array}{l}\text { Phenol, bisphenol A, 4- } \\
\text { tert-butylphenol, } \\
\text { EDCs, PPCPs, } \\
\text { antibiotic resistance } \\
\text { genes, SS, } \\
\text { perfluoroalkyl and } \\
\text { polyfluoroalkyl } \\
\text { substances, organic } \\
\text { compounds, metals }\end{array}$ & $\begin{array}{l}\text { - Simple construction } \\
\text { - Low operation and maintenance costs } \\
\text { - Reduced environmental impact } \\
\text { - Energy intensive } \\
\text { - High efficiency of pollutant removal } \\
\text { - High adaptability in tropical environments }\end{array}$ & $\begin{array}{l}\text { High investment cost } \\
\text { Large space requirement and difficult to control } \\
\text { Poor performance in winter }\end{array}$ & $\begin{array}{l}\text { (Bove et al., } \\
\text { 2015) } \\
\text { (J. Gao et al., } \\
\text { 2015) } \\
\text { (Kamaruddin } \\
\text { et al., 2017) } \\
\text { (Costa et al., } \\
\text { 2019) } \\
\text { (Kurniawan et } \\
\text { al., 2010) }\end{array}$ \\
\hline Membrane bioreactor & $\begin{array}{l}\text { COD, organic matter } \\
\text { (BOD and ammonia) } \\
\text { and suspended solids }\end{array}$ & $\begin{array}{l}\text { - Les sensitive to variation in leachate features } \\
\text { - } \text { clarification of post-digestion settlement and } \\
\text { - Limited space requirements, } \\
\text { - Simple monitoring of sludge age } \\
\text { Less sludge generation }\end{array}$ & $\begin{array}{l}\text { - High membrane costs, washing, potential replacement } \\
\text { and maintenance due to clogging } \\
\text { - High energy consumption and requires skilled operator } \\
\text { - Membranes are susceptible to fouling and foaming }\end{array}$ & $\begin{array}{l}\text { (Roy et al., } \\
2018 \text { ) } \\
\text { (Narayan et } \\
\text { al., 2019) (N. } \\
\text { Laitinen, A. } \\
\text { Luonsi, \& J. J. } \\
\text { D. Vilen, } \\
\text { 2006) }\end{array}$ \\
\hline $\begin{array}{l}\text { Moving-bed, fluidized- } \\
\text { bed and suspended-carrier } \\
\text { biofilm reactors }\end{array}$ & COD and ammonium & $\begin{array}{l}\text { Higher biomass concentrations in the reactor } \\
\text { - Short sludge-settling times } \\
\text { Weak sensitivity to toxic compounds }\end{array}$ & - High capital and operating cost & $\begin{array}{l}\text { (Luo et al., } \\
\text { 2020) (Renou } \\
\text { et al., 2008) } \\
\text { (Kamaruddin } \\
\text { et al., 2017) } \\
\end{array}$ \\
\hline $\begin{array}{l}\text { Rotating biological } \\
\text { contractors }\end{array}$ & Nitrogen-nitrate, COD & $\begin{array}{l}\text { - Small footprint and less energy consumption } \\
\text { - Easy operation with lower maintenance } \\
\text { requirements } \\
\text { - } \text { Abundant bacterial growth } \\
\text { - Sot sensitive to toxins and load variations } \\
\text { - Specially adapted for small communities } \\
\end{array}$ & $\begin{array}{l}\text { - Low removal efficiency } \\
\text { - High capital costs } \\
\text { - } \text { Not suitable for high-strength leachate tretment } \\
\text { - Adversely affected by low temperatures }\end{array}$ & $\begin{array}{l}\text { (Kurniawan et } \\
\text { al., 2010) } \\
\text { (Wiszniowski } \\
\text { et al., 2006) } \\
\text { (Bove et al., } \\
\text { 2015) } \\
\end{array}$ \\
\hline
\end{tabular}




\begin{tabular}{|c|c|c|c|c|}
\hline & & - Cold tolerance and less sludge generation & & $\begin{array}{l}\text { (Kamaruddin } \\
\text { et al., 2015) } \\
\text { (Kamaruddin } \\
\text { et al., 2017) }\end{array}$ \\
\hline $\begin{array}{l}\text { Anaerobic sequencing } \\
\text { batch reactor (ASBR) }\end{array}$ & Organic matter & $\begin{array}{l}\text { Better effluent quality control } \\
\text { Suitable process control and high solids } \\
\text { retention }\end{array}$ & & $\begin{array}{l}\text { (Contrera et } \\
\text { al., 2014) }\end{array}$ \\
\hline Trickling biofilters (TFs) & $\begin{array}{l}\mathrm{SS}, \mathrm{COD}, \mathrm{BOD}, \mathrm{NH}_{4}^{+}- \\
\mathrm{N} \text {, and turbidity }\end{array}$ & $\begin{array}{l}\text { Simultaneous nitrogen and carbon removal } \\
\text { Low cost operating systems and filter media } \\
\text { that can withstand some level of influent load } \\
\text { variation }\end{array}$ & $\begin{array}{l}\text { - Possible clogging and growth of fungi or algae } \\
\text { - Unavoidable obstructions caused by biomass }\end{array}$ & $\begin{array}{l}\text { (Bove et al., } \\
\text { 2015) (Renou } \\
\text { et al., 2008) } \\
\text { (Kamaruddin } \\
\text { et al., 2017) }\end{array}$ \\
\hline $\begin{array}{l}\text { Upflow anaerobic sludge } \\
\text { blanket (UASB) }\end{array}$ & & $\begin{array}{l}\text { High treatment efficiency and conversion of } \\
\text { organic matter in leachate into methane and } \\
\mathrm{CO}_{2}\end{array}$ & $\begin{array}{l}\text { - Sensitivity to toxic substances } \\
\text { - Short HRT }\end{array}$ & $\begin{array}{l}\text { (J. Gao et al., } \\
\text { 2015) } \\
\text { (Kurniawan et } \\
\text { al., 2010) }\end{array}$ \\
\hline Fungal treatment & $\begin{array}{l}\text { Acids, lignin, cellulose } \\
\text { and hemicellulose }\end{array}$ & $\begin{array}{l}\text { - Beneficial for leachate treatment during the } \\
\text { whole lifecycle of landfills }\end{array}$ & & $\begin{array}{l}\text { (Luo et al., } \\
2020 \text { ) }\end{array}$ \\
\hline
\end{tabular}

Table 4. Most suitable leachate treatment technologies according to landfill age

\begin{tabular}{|c|c|c|c|}
\hline Landfill age & Young & Intermediate & Mature \\
\hline \multirow[t]{7}{*}{ Treatment technology } & $\begin{array}{l}\text { Rotating Biological Contactors, } \\
\text { Co-treatment with sewage }\end{array}$ & Co-treatment with sewage & $\begin{array}{l}\text { biological activated carbon fluidized } \\
\text { bed process }\end{array}$ \\
\hline & Electrochemical oxidation & Coagulation-flocculation & Coagulation-flocculation \\
\hline & Ammonium stripping & Sequencing batch reactor & advanced oxidation processes (AOP) \\
\hline & Anaerobic digestion & Membrane bioreactor & Membrane bioreactor \\
\hline & Fungal treatment & & Anaerobic ammonium oxidation \\
\hline & Membrane bioreactor & & \\
\hline & Rotating biological contactors & & \\
\hline
\end{tabular}


Table 5. Common precipitants, coagulants and adsorbents for leachate treatment (Abuabdou et al., 2020; J. Gao et al., 2015; Ghaleb et al., 2020; A. Jagaba, Kutty, Hayder, Baloo, Ghaleb, et al., 2020; A. Jagaba, Kutty, Hayder, Latiff, et al., 2020; Kamaruddin et al., 2017; Khoo et al., 2020; Kurniawan et al., 2006; Kurniawan et al., 2010; Luo et al., 2020; Mojiri, Ohashi, Ozaki, \&

\begin{tabular}{|c|c|c|c|c|c|c|c|c|}
\hline \multicolumn{9}{|c|}{ Kindaichi, 2018) } \\
\hline \multirow{2}{*}{$\begin{array}{l}\text { Chemical } \\
\text { precipitants }\end{array}$} & \multirow[t]{2}{*}{ Oxidants } & \multirow{2}{*}{$\begin{array}{l}\text { Ion exchange } \\
\text { materials }\end{array}$} & \multirow[t]{2}{*}{ Electrodes } & \multirow[t]{2}{*}{ Fungi used } & \multirow{2}{*}{$\begin{array}{l}\text { Constructed } \\
\text { Wetland } \\
\text { plants }\end{array}$} & \multirow{2}{*}{$\begin{array}{l}\text { Coagulants/ } \\
\text { Flocculant/ Coagulant } \\
\text { aids }\end{array}$} & \multicolumn{2}{|l|}{ Adsorbents } \\
\hline & & & & & & & $\begin{array}{l}\text { Conventional } \\
\text { activated } \\
\text { carbon }\end{array}$ & Non-conventional adsorbents \\
\hline $\begin{array}{l}\text { Struvite, } \\
\text { Hydrated } \\
\text { lime } \\
\mathrm{Ca}(\mathrm{OH})_{2} \text {, } \\
\text { Quicklime, } \\
\text { Magnesium } \\
\text { hydroxide, } \\
\text { Sodium } \\
\text { hydroxide }\end{array}$ & $\begin{array}{l}\text { Ozone }\left(\mathrm{O}_{3}\right), \\
\text { Hydrogen } \\
\text { peroxide } \\
\left(\mathrm{H}_{2} \mathrm{O}_{2}\right), \\
\text { Chlorine, } \\
\text { calcium } \\
\text { hydrochloride, } \\
\text { potassium } \\
\text { permanganate, }\end{array}$ & $\begin{array}{l}\text { Cationic } \\
\text { exchange, } \\
\text { chelating and } \\
\text { adsorbent resins, } \\
\text { acidic ion } \\
\text { exchange resins } \\
\text { (DowexM4195 } \\
\text { and Amberlite } \\
\text { IR120 resins), } \\
\text { naturally } \\
\text { occurring } \\
\text { kaolinite, silicate } \\
\text { and zeolites } \\
\text { minerals, } \\
\text { activated carbon, } \\
\text { bentonite, } \\
\text { cockleshell, and } \\
\text { limestone }\end{array}$ & $\begin{array}{l}\text { Aluminium, } \\
\text { iron }\end{array}$ & $\begin{array}{l}\text { White-rot } \\
\text { fungus } \\
\text { Dichomitus } \\
\text { squalens, } \\
\text { white-rot fungus } \\
\text { Trametes trogii } \\
\text { Phanerochaete } \\
\text { chrysosporium, } \\
\text { Bjerkandera } \\
\text { adusta }\end{array}$ & $\begin{array}{l}\text { Duckweed, } \\
\text { bulrush, } \\
\text { pondweed, } \\
\text { reeds, cattails } \\
\text { Acacia } \\
\text { confuse, } \\
\text { A. magnium, } \\
\text { A. } \\
\text { auriculiformis } \\
\text { and Eichornia } \\
\text { crasipes }\end{array}$ & $\begin{array}{l}\text { Coagulants: organic } \\
\text { biopolymers, } \mathrm{FeCl}_{3} \text {, } \\
\text { Aluminum sulfate, } \\
\text { Hibiscus rosa-sinensis, } \\
\text { poly ferric sulphate, } \\
\text { polyaluminum chloride, } \\
\text { Lateritic soil, } \\
\text { Psyllium husk, } \\
\text { O. basilicum, } \mathrm{KMnO}_{4} \text {, } \\
\mathrm{Fe}_{2}\left(\mathrm{SO}_{4}\right)_{3} \\
\text { Flocculant: } \\
\text { Polyacrylamide, } \\
\text { polyacrylamide grafted } \\
\text { gum ghatti } \\
\text { Coagulant aids: } \\
\text { polyelectrolyte } \\
\text { compounds, }\end{array}$ & $\begin{array}{l}\text { Commercial } \\
\text { PAC, } \\
\text { DARCO, } \\
\text { granular } \\
\text { activated } \\
\text { carbon, Calgon } \\
\text { Filtrasorb 400, } \\
\text { Norit 0.8, } \\
\text { Norit SA 4, } \\
\text { Picacarb 1240, } \\
\text { Chemviron } \\
\text { AQ40, } \\
\text { Carbotech }\end{array}$ & $\begin{array}{l}\text { Bamboo dust, chitin, corncob, } \\
\text { lignite, palm shell, peat, rice } \\
\text { husk, pall fiber, chitosan, fungi, } \\
\text { moss, sago waste, durian peel, } \\
\text { sawdust, rattan sawdust, palm } \\
\text { oil fuel ash, palm fibre, } \\
\text { sugarcane bagasse, coffee } \\
\text { ground, tea leaves, bottom ash, } \\
\text { pinewood,maize cob, orange } \\
\text { peel, sand filter, palm stone, } \\
\text { coir pith, Sphagnum peat, } \\
\text { magnetic particles, tamarind } \\
\text { fruit seed, zeolite, fly ash, illite, } \\
\text { keolinite, iron fines, activated } \\
\text { salumina, banana frond, } \\
\text { municipal waste incinerator, } \\
\text { bone meal, bark husk and } \\
\text { vermiculite activated alumina }\end{array}$ \\
\hline
\end{tabular}




\subsection{Sequencing Batch Reactor (SBR) System}

These are non-steady-state, variable-capacity and suspended-growth biological wastewater treatment systems that uses the fill and draw activated sludge system with clarifier and an intermittent aeration mode where Almost all metabolic reactions and the segregation of solid-liquid in a unit tank through a timed control sequence (Alattabi et al., 2017). The traditional SBR is an integrated nitrification-denitrification process, during which ammonia $\left(\mathrm{NH}_{3}-\mathrm{N}\right)$ is first oxidized to nitrite $\left(\mathrm{NO}_{2}-\mathrm{N}\right)$, followed by $\mathrm{NO}_{2}-\mathrm{N}$ to $\mathrm{NO}_{3}-\mathrm{N}$ oxidation and final production of nitrogen gas $\left(\mathrm{N}_{2}\right)(\mathrm{S}$ Abubakar, Latiff, Lawal, \& Jagaba, 2016; Y. Duan et al., 2020). It blends both anaerobic and aerobic stages to successfully achieve nitrification, denitrification and phosphorous removal concurrently (SNDPR) (S. X. Gao, He, \& Wang, 2020).

\subsection{Applications of SBR}

SBR is used to eliminate high strength organic and inorganic pollutants, nutrients and SS from leachate in a single tank. Thus, it has several other applications as highlighted below:

i. Wastewater treatment:

This involves treatment of:

- $\quad$ reject, flowback and shrimp aquaculture pond water.

- abattoir, biodiesel, cooking, cassava, dairy, domestic, dye, ethanol, formaldehyde, grey, marine, petrochemical, pharmaceutical, piggery, saline, slaughterhouse, swine, textile, whey, woodchips wastewater have also been reported for treatment by SBR.

- $\quad$ acrylic fiber, mustard tuber, duck house, olive mill, phenol-laden, opto-electronic, motorway service area and vegetable oil-containing wastewater.

- $\quad$ beverage, o-nitrobenzaldehyde, paper, soybean, tapioca, tofu and agro-based industrial wastewaters

- palm oil mill and wine distillery effluent, tannery soak liquor, urine, and leachate

ii. Biogas generation: biohydrogen $\left(\mathrm{BioH}_{2}\right)$, nitric oxide $(\mathrm{NO})$, thermophilic biomethane, carbon dioxide $\left(\mathrm{CO}_{2}\right)$, trihalomethane, nitrous oxide $\left(\mathrm{N}_{2} \mathrm{O}\right)$

iii. Solid waste digestion: in the SBR system involves the following waste biosolids:

- de-oiled jatropha, fatty solid, food, kitchen, tannery and winery waste

- $\quad$ aquaculture systems, sewage and municipal waste sludge

- dairy manure, brewery and pig slurry, PAH-contaminated lagoon sediments, fruit distillation stillage, refinery spent caustic, sulfur rich macroalgal biomass, thermomechanical pulping condensate and pressate.

iv. Granulation: SBR enhances the generation of aerobic, fluffy, nitritation, nitrifying bacteria, Anammoxenriched, water-born algal-bacterial, biomass and activated sludge, filamentous and Phosphorus accumulating, ammonia oxidizers, and hydrogen-producing granules. The system has the advantage of effectively using the generated granules in several biological treatment systems for pollutants degradation in wastewater.

v. Co-digestion: SBR is a promising technique for economical co-digestion of tannery wastewater + tannery solid waste, landfill leachate + dairy wastewater, landfill leachate + domestic wastewater, abattoir wastewater + fruit $\&$ vegetable waste, sewage sludge + food waste, dairy cow manure + wheat straw and molasses with liquid swine manure.

vi. Bioremediation: TPH contaminated soil, tetryl-contaminated soil

vii. Fermentation: Cheese whey, food waste

viii. Biodiesel and biosurfactant production

ix. Biodegradable polymer production

\subsection{Factors affecting SBR}

SBR system performance may be influenced by several factors to include: influent characteristics, organic loading rate, carbon source, pH, DO, ORP HRT, SRT, feed pattern, anoxic/oxic ratio, cycle length, settleability and temperature (Rollemberg et al., 2019). Short settling time selects rapid settling bacteria while poor settleability sludge is effectively removed. Low temperature is considered a severe challenge in simultaneous $\mathrm{N}$ and $\mathrm{P}$ removal systems, and receives exploration because it has an unfavorable impact on microbial activity in activated sludge (Sekine, Akizuki, Kishi, \& Toda, 2018).

\subsection{Advantages of SBR system}

Despite the consequences resulting from the aforementioned factors affecting SBR system, it has the following benefits: (i) require small footprint, single basin operation with no secondary clarifier required (Alattabi et al., 2017), operated automatically with excellent process control possibilities (Abd Nasir et al., 2019). (ii) Simple and flexible in configuration and operation, Low installation and operation cost (Mojiri et al., 2018), high tolerance to various loading shocks with good bulking control (S. Y. Li, Fei, Cao, \& Chi, 2019). (iii) Robustness, higher biomass retention, reduced 
energy consumption, endurance to toxicity, SRT decoupling from HRT and simultaneous organics, nitrogen and phosphorus (Chao et al., 2020; Dutta \& Sarkar, 2015).

\subsection{SBR process description}

The basic operation cycle of an SBR is composed of five sequence stages. They are: Fill, React, Settle, Draw, and Idle Fill: At the filling stage, reactor is loaded with wastewater mixed with biomass by either gravity or pumping between reactor low and high-water levels for microbial activity. The fill strategy which may be controlled by a timer could be aerated, static and mixed fill. In static filling, the available biomass in the SBR is combined with influent wastewater without mixing. Pulse substrate feeding is used for filling, where fill and reaction periods are separated. During the mixed fill, otherwise called "simultaneous filling and decanting - reaction - settling" at constant volume, combined long fill and reaction periods could be beneficial for treating high-strength inhibitory wastewater. Both mixing and aeration occur in the reaction filling stage. Fill length relies on reactor quantity, volume and the flow rate of the effluent. Usually, the durations last for $25 \%$ of the entire cycle time. Determination of feed volume depends on desired loading, detention time and expected settling characteristics of the organisms while time to fill depends on extent of diurnal variations in the influent flow rate, reactor capacity and number of parallel reactors in operation.

React: In the reaction point, the flow of wastewater to the reactor is limited while the initial filling reaction continues and expected to be terminated by aeration and mixing. Reactions started during filling are accomplished to provide high level of nutrients removal. The reaction time can be designed to exceed $50 \%$ of the total cycle time. However, react phase duration may depend on liquid control levels in a multi-tank system, timers or when the degree of treatment required has been reached. Treatment to obtain anaerobic, anoxic, or aerobic conditions is regulated by air, either on or off.

Settle: In the settle stage, the reactor functions as a serial clarifier without any injection or discharge. MLSS settles, allowing the formation of a clear supernatant in the upper level of the reactor. The settle period last between 15-20\% of the total cycle time to forbid solid cover from floating as a result of gas build-up.

Draw: In this stage, either fixed, floating pipe or adjustable weirs withdrawal mechanism is adopted to discharge the clarified supernatant after a substantial depth of supernatant has been formed. Designed draw time can vary from 5 to $>30 \%$ of the total cycle duration.

Idle: It is basically the time needed between the draw and fill stage when several reactors are in active at a given time. In this stage, biomass mixing to condition the reactive contents is carried out. After settling, excess activated sludge is wasted as the MLSS would have reached maximum solids concentration (Alattabi et al., 2017; Dutta \& Sarkar, 2015; S. X. Gao et al., 2020; Sekine et al., 2018).

\subsection{SBR operating scales}

This study overviews latest studies carried out by the bench, laboratory, pilot and full-scale SBR systems for application in leachate treatments.

\subsubsection{Laboratory scale}

The main aim of using laboratory scale reactors is to investigate the potential economic and environmental sustainability of the system and later use the findings for possible pilot and full scale SBR design. The laboratory scale reactors vary in size and shapes using different materials ranging from plastic, thermoplastic, glass, etc. They are mostly compatible with flexibility potential. The laboratory-scale SBRs were used to extract carbon and nutrients and also to establish biodegradability assays for wastewater. A laboratory scale SBR study investigated the viability of leachate co-treatment with synthetic wastewater using respirometric techniques, in terms of operational efficiency and biomass behavior. The results showed good COD and $\mathrm{NH}_{4}{ }^{+}-\mathrm{N}$ removal efficiencies with significant respiration rates obtained for the heterotrophic population. Thus, suggesting and confirming the feasibility of leachate co-treatment with a readily biodegradable wastewater (Capodici et al., 2014).

Alternating anoxic/aerobic conditions for nitrogen extraction in a laboratory scale SBR, transient instability of aerobic granules associated with filamentous outgrowth was observed. Granules and flocs interbred in the same reactor, with unique composition and structure of aggregates. Data showed complete elimination of nitrogen, with temporary accumulation of nitrite in the aerobic phase until maximum depletion of ammonia. Microbial biomass evaluation revealed that granules contained the majority of the nitrite-oxidizing bacteria (NOB) while the ammoniumoxidizing bacteria (AOB) appeared to be more abundant in the flocs (Carvalho, Meyer, Yuan, \& Keller, 2006). Sludge reduction through returned biomass fasting coupled with nutrient removal was successfully demonstrated using two laboratory scale SBRs. Sustainable enhanced biological phosphorus removal (EBPR), nitrification and sludge reduction could be maintained in the modified SBR when operated at a finite SRT with an observed biomass yield of $0.07 \mathrm{mg}$ TSS mg/L COD. (Datta, Liu, \& Goel, 2009). 
In terms of greenhouse gas emission, $\mathrm{NO}$ and $\mathrm{N}_{2} \mathrm{O}$ accumulation during nitrite denitrification could be due to low $\mathrm{pH}$ and high influent loading especially in leachate. $\mathrm{N}_{2} \mathrm{O}$ production during nitrogen removal was investigated in a lab-scale aerobic-SBR. Results showed that the generation of $\mathrm{N}_{2} \mathrm{O}-\mathrm{N}$ was $>1.87 \mathrm{mg} / \mathrm{L}$ and converted to $\mathrm{N}_{2} \mathrm{O}$ by up to $4 \%$ of the nitrogen taken out. $\mathrm{No}_{2} \mathrm{O}$ was generated during denitrification as nitrification was the key source of $\mathrm{N}_{2} \mathrm{O}$ production during nitrogen removal. Denitrification, therefore, had the ability to regulate production of $\mathrm{N}_{2} \mathrm{O}(\mathrm{X}$. $\mathrm{H}$. Liu, Peng, Wu, Akio, \& Peng, 2008). The diagnosis of acidification and efficient recovery of a lab-scale anaerobic SBR (ASBR) showed that acidification occurred on the seventh day after adding $20 \mathrm{mmol} / \mathrm{L}$ of sodium 2bromoethanesulfonate into the reactor. This frustrated the methane production rate. Results indicated that the acidified ASBR can be revived in approximately $50 \mathrm{~d}$. Large amounts of Methanosarcina-like and rod-shaped methanogens were distributed in the sludge flocs after reactor restoration and ensured that the fermentative, acidogenic, and methanogenic processes proceeded effectively in the anaerobic system (Hou et al., 2015).

In a comparative study, the efficiency and consistency of a full-scale SBR plant can be assessed by a lab-scale SBR as proven by (Schwitalla et al., 2008) where the amounts of $\mathrm{NH}_{4}{ }^{+}-\mathrm{N}$ desorption and desorption using one normal $\mathrm{KCl}$ solution $\mathrm{NH}_{4} \mathrm{Cl}$ during one cycle slightly vary among the five analyzed full-scale SBR plants. The tendencies for both $\mathrm{NH}_{4}{ }^{+}-\mathrm{N}$ desorption and adsorption capacities were consistent. The desorption minima occur at the end of nitrification as well as up to one hour afterwards while the activated sludge samples had the highest adsorption capacities after the nitrification phase.

\subsubsection{Bench scale}

Bench scale SBR are small scale systems placed on either a laboratory worktable, glovebox or in a lab hood to handle wastewater $\leq 50 \mathrm{~L} / \mathrm{d}$ at a given point in time depending on flow rates. They are fabricated and used to substantiate that the system can be safely operated and capable of yielding desired product before scaling up to either laboratory, pilot or full-scale systems. Most of the pilot- and full-scale systems use constant-volume SBRs since they have a simpler operation than conventional SBRs, whose filling and decanting phases must be carried out in a relatively short period of time and applying a large pumping system (Rollemberg et al., 2019). In studies with bench-scale units, high production of a viscous slime-like material known as extracellular polymers (EPS) or exopolysaccharides could be observed. Thus, primarily causing a reduction of mass transfer fluxes and decreasing the organic matter removal (Miqueleto, Dolosic, Pozzi, Foresti, \& Zaiat, 2010). According to literature, gradually increasing municipal sludge deep dewatering filtrate (MSDDF) in a bench scale SBR up to 84 days led to the domestication of stable Aerobic granular sludge (AGS) of yellowish-brown coloration, dense and irregular sphere with excellent degradation performance. The reactor yielded $95 \%, 96 \%, 99 \%$ and $88 \%$ for $\mathrm{COD}, \mathrm{TN}, \mathrm{NH}_{4}{ }^{+}-\mathrm{N}$ and TP removals respectively (Long, $\mathrm{Yang}$, $\mathrm{Pu}$, Yang, Shi, et al., 2014). AGS can be successfully cultivated rapidly in a bench scale SBR within 21 days. Bench scale SBR strictly controlled in the laboratory were used to obtain strategies for AGS stability enhancement. These include: applying appropriate operational parameters; reinforcing granular core, enrichment of slow-growing organisms; strengthening granular core or the inhibition of anaerobic activity (Long et al., 2019).

\subsubsection{Pilot scale}

Studies on laboratory scale SBR has facilitated design specifications and operational parameters necessary for the construction and operation of a pilot-scale system. The system is scaled up for treating up to $50 \%$ of a total actual flow. To ensure high performance efficiencies of pilot scale systems, laboratory scale study is required prior to implementation. Although the results obtained with SBR systems at laboratory scale are promising, there are few studies carried out at pilot scale. Therefore, more information about granulation, biogas production, solid waste digestion and nutrients degradation alongside their performance at larger scale is needed to confirm if SBR application at large scale with attached control systems could be feasible for leachate treatment (Yang et al., 2009).

Four automated DO control strategies in a pilot SBR were tested and evaluated: ON/OFF, PID, fuzzy and composite fuzzy control strategies. Study concludes that the composite fuzzy control strategy is proved to be the robust and effective controller for the DO concentration (Shen, Tao, Ning, Liu, \& Ieee, 2012). A pilot-scale SBR system using different HRTs was developed and applied. Results showed that COD removal efficiencies are 72.5, 87.8, 98.4, 98.4\%, for the different HRTs of 5, 3, 1, and 0.5, 1, 3 and $5 \mathrm{~d}$, respectively while BOD removals were 58.0, 90.4, 99.3 and 99.6\% respectively. Thus, the pilot-scale SBR system as depicted in Fig. 3 with automation was feasible, effective to be certified for use in wastewater treatment (Su, Huang, Wang, \& Hong, 2018). Modified IWA activated sludge model No 3 (ASM3) described the dynamics of a pilot-scale SBR during its cyclic operation (Ni et al., 2009). A pilot-scale anaerobic sequence batch biofilm reactor (AnSBBR) could be an option for anaerobic pretreatment of landfill leachate, because COD removal efficiency exceeded $70 \%$ with high biodegradability. The first-order kinetic model is adequate for the simulation and expansion of these leachate treatment systems (Contrera et al., 2014). In another report, pilotscale $\mathrm{H}_{2}$-producing ASBR was operated at various $\mathrm{C} / \mathrm{N}$ ratios. At $\mathrm{C} / \mathrm{N}$ ratio $>20, \mathrm{H}_{2}$ production yield dropped and accompanied by increased production of lactate, propionate, and valerate. Alkaline shock of the whole mixed liquor 
significantly enhanced the $\mathrm{H}_{2}$ yield (Kim, Kim, Kim, \& Shin, 2010). Pilot scale capacity depends on factors as, wastewater influent volume and composition, available land, funding etc. According to literature, the capacity ranged from $1-3000$ L. Nitrification denitrification process in a pilot SBR was however achieved with a lower rate than that observed in the lab-scale system. This might be attributed to the lower temperature $\left(25^{\circ} \mathrm{C}\right)$ and the composition of the raw wastewater treated in the pilot system, compared with the operating conditions of the lab-scale SBR system (Kornaros, Marazioti, \& Lyberatos, 2008). Findings revealed that it takes 30 min to completely oxidize Fe(II) in a pilotscale SBR, and with further optimization of SBR operation the number of cycles required to achieve acceptable Fe(II) oxidation can be reduced (Zvimba, Mathye, Vadapalli, Swanepoel, \& Bologo, 2013).

Aerobic granulation of activated sludge was successfully developed in a pilot-scale SBR using the selection pressure and crystal nucleus method under sludge age control. It took the pilot-scale SBR around 400 days to turn activated sludge into granule-dominant sludge compared with 1 or 2 months needed by a lab-scale reactor for aerobic granulation. The cultivated aerobic granular sludge under high influent quality fluctuation was irregular, pale yellow coloration, average particle size and could maintain long-term structural stability under short setting time environment. $\mathrm{NH}_{4}{ }^{+}-\mathrm{N}, \mathrm{COD}$, and TN removal efficiencies were above 98, 80 and 50\%, respectively (Long, Yang, Pu, Yang, Jiang, et al., 2014).

\subsubsection{Full Scale}

The full-scale reactor represents the original and final prototype designed, constructed and operated on site. It is mostly in a large-scale format representing a treatment plant. Studies from the pilot scale system usually facilitates the design parameters and operational conditions necessary for the development of full-scale SBR. Well-designed full-scale SBR as depicted in Fig. 4 allows a reduction of the landmass needed for land application of wastewater treatment by about 75\% (Lo \& Liao, 2007). Full-scale applications are regulated using punctual fillings. Significant denitrification rate and a part phosphorus-release during sedimentation phase takes place at a higher rate with additional filling. According to (H. Fernandes, Jungles, Hoffmann, Antonio, \& Costa, 2013), influent quality variations were responsible for significant changes in the microbial composition over time as depicted by band profile. In a Full-scale SBR study, mature aerobic granules with a compact structure, average $\mathrm{SVI}_{30}$ of $47.1 \mathrm{~mL} / \mathrm{g}$, diameter of $0.5 \mathrm{~mm}$, and settling velocity of $48 \mathrm{~m} / \mathrm{hr}$ were obtained after 337 days of operation from a full-scale SBR while low DO, temperature or influent $\mathrm{COD} / \mathrm{N}$ were responsible for higher $\mathrm{N}_{2} \mathrm{O}$ emission (Sun, Cheng, \& Sun, 2013).

Modelling is suitable for the operation and optimization of full-scale SBR plants. Activated Sludge Model No. 1 (ASM1) and its variations (ASM2d and ASM3) with the advantage of easy cycle adaptation were used to forecast the behavior of a full-scale SBR employed to treat wastewater, predict and mitigate $\mathrm{N}_{2} \mathrm{O}$ production and emission. Utilizing ASIM® software and adopting the ASM1 model, a study identified nitrifier denitrification as the major biological process for $\mathrm{N}_{2} \mathrm{O}$ production using $\mathrm{N}_{2} \mathrm{O}$ data of two different cycles for the model calibration (Massara et al., 2017). In a similar study, ASM1 model best simulates a one-input cycle while the ASM3 model was the best for the step-feed cycle. The one-input cycle gave better nutrient removal. However, the step-feed cycle was harder to calibrate (Oselame, Fernandes, \& Costa, 2014). The ASM3 model effectively operated even under perturbation conditions and accurately simulate short-term effects arising from the variation of influent organic loadings such as in leachate. 


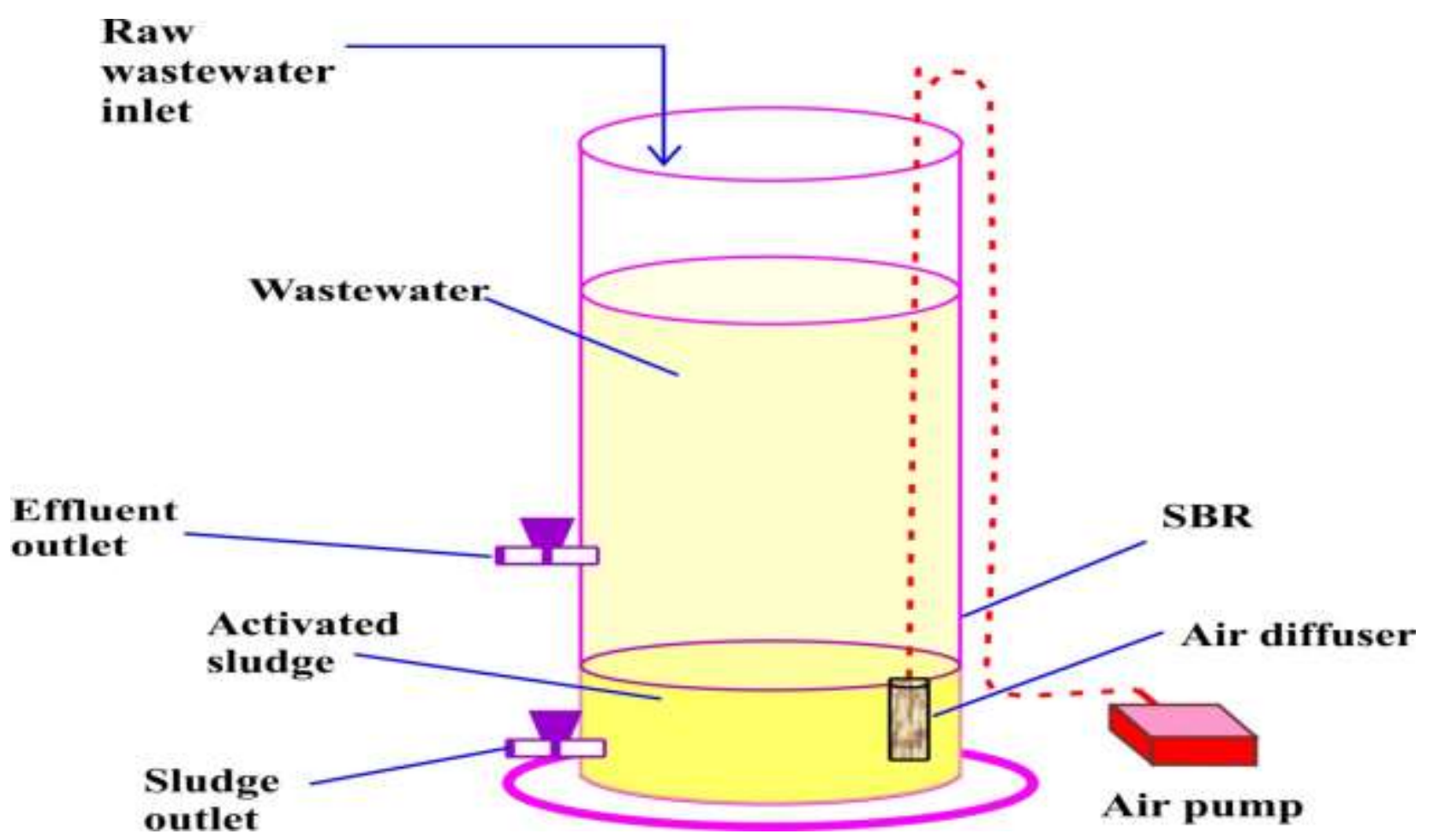

Fig. 3. Sketch of the SBR for treating wastewater (Su et al., 2018)

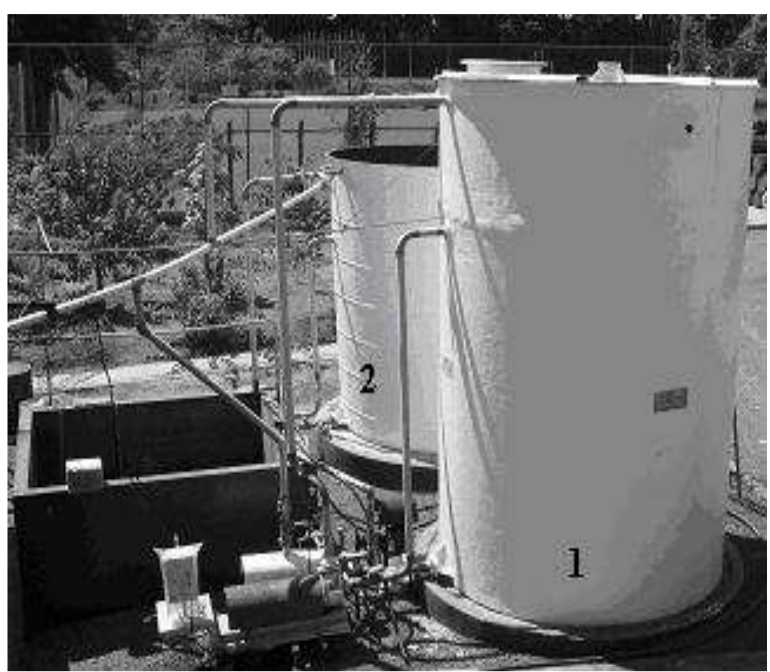

(a)

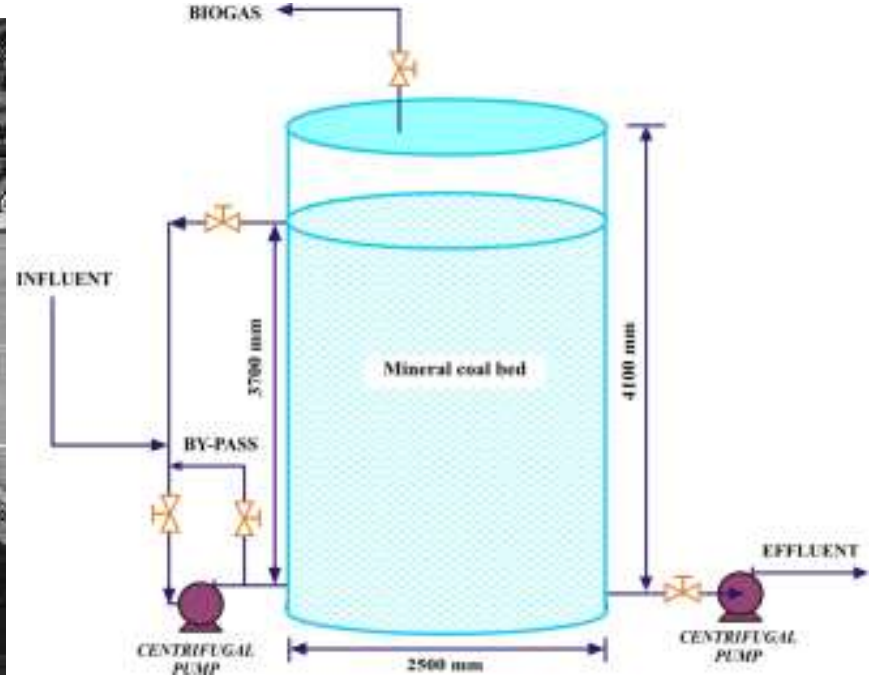

(b)

Fig. 4. (a) Prototype of the ASBBR (1) and the storage tank (2) (b). Sketch for the full scale ASBBR reactor (Sarti, Silva, Zaiat, \& Foresti, 2011).

The performance of various reactors for treating young, intermediate and mature leachate is summarized in Table 6. This is to clearly state the contribution of SBR system in treating landfill leachate. The table further explain the notable observations made during each study in the remark section. It could be observed that most treatment focused on cost-effectiveness of the system, sludge reduction, improved granulation and resistance to shock loadings due to leachate influent variability. 
Table 6. SBR leachate removal efficiency

\begin{tabular}{|c|c|c|c|c|c|c|c|c|c|}
\hline \multicolumn{10}{|c|}{ Table 6. SBR leachate removal efficiency } \\
\hline $\begin{array}{l}\text { Leachate } \\
\text { age }\end{array}$ & $\begin{array}{c}\text { Influent } \\
\text { characteristics }\end{array}$ & Reactor system & $\begin{array}{l}\text { Reactor } \\
\text { operating } \\
\text { capacity } \\
\text { (L) }\end{array}$ & $\begin{array}{c}\text { Cycle } \\
\text { time } \\
\text { (h) }\end{array}$ & $\begin{array}{l}\text { HRT } \\
\text { (d) }\end{array}$ & $\begin{array}{l}\text { SRT } \\
\text { (d) }\end{array}$ & $\begin{array}{c}\text { Removal } \\
\text { efficiency } \\
(\%)\end{array}$ & Remarks & Ref. \\
\hline Intermediate & $\begin{array}{l}\text { Mg:N:P: } 1.2: 1: 1, \mathrm{SVI}_{5}: \\
47 \mathrm{~mL} / \mathrm{g}, \mathrm{MLSS}, 4000 \\
\mathrm{COD}, \mathrm{NH}_{4}{ }^{+}-\mathrm{N}, 4950 \\
(\mathrm{mg} / \mathrm{L}), 120 \mathrm{~L} / \mathrm{h}\end{array}$ & $\begin{array}{l}\text { Granule } \\
\text { sequencing batch } \\
\text { reactors (GSBR) }\end{array}$ & 3 & 12 & & $25-35$ & $\begin{array}{l}\text { COD: } 84.4 \\
\mathrm{NH}_{4}{ }^{+}-\mathrm{N}: 92.3\end{array}$ & $\begin{array}{l}\text { - Organics biodegradation rate decreased as influent } \\
\text { ammonium increased. } \\
\text { - pH failed to follow the reaction processes for all of the } \\
\text { influent ammonium concentrations. } \\
\text { - DO variations were consistent with GSBR output observed at } \\
\text { low ammonium inputs }\end{array}$ & $\begin{array}{l}\text { (Y. J. } \\
\text { Wei et } \\
\text { al., } \\
\text { 2012) }\end{array}$ \\
\hline Mature & $\begin{array}{l}\text { pH: 8.4, COD, 2456; TN, } \\
375 ; \mathrm{PO}_{4}-\mathrm{P}, 8.2 ; \\
\mathrm{NH}_{4}-\mathrm{N}, 238 ; \mathrm{MLSS} \\
7000(\mathrm{mg} / \mathrm{L})\end{array}$ & $\begin{array}{l}\text { Membrane } \\
\text { Sequencing } \\
\text { Batch Reactor } \\
\text { (MSBR) }\end{array}$ & 5 & 12 & 10 & 120 & $\begin{array}{l}\text { COD: } 60 \\
\text { TN: } 88 \\
\mathrm{PO}_{4}-\mathrm{P}: 45 \\
\mathrm{NH}_{4}-\mathrm{N}: 100\end{array}$ & $\begin{array}{l}\text { - Cost-effective method with pure methanol addition to } \\
\text { enhance system denitrifying capacity } \\
\text { - No sludge wastage while high SRT and low biodegradability } \\
\text { of some leachate compounds were responsible for the weak } \\
\text { COD removal. } \\
\text { - Direct } \mathrm{KH}_{2} \mathrm{PO}_{4} / \mathrm{K}_{2} \mathrm{HPO}_{4} \text { addition resulted in PO4-P } \\
\text { accumulation in the treated effluent; }\end{array}$ & $\begin{array}{l}\text { (Tsilo } \\
\text { georgi } \\
\text { s et } \\
\text { al., } \\
\text { 2008) }\end{array}$ \\
\hline Mature & $\begin{array}{l}\text { BOD/COD: 0.1, DO, } \\
3.0 ; \mathrm{COD}, 4250 ; \mathrm{BOD},< \\
430 ; \mathrm{NH}_{4}^{+}, 750-800 ; \\
\text { chloride, } 2300-2500 \\
(\mathrm{mg} / \mathrm{L}), 18-20^{\circ} \mathrm{C}\end{array}$ & SBR & 5 & 24 & 12 & 10 & $\begin{array}{l}\text { COD: } 98.8 \\
\text { BOD: } 98.6 \\
\text { TKN: } 80.2\end{array}$ & $\begin{array}{l}\text { - System efficiency decreased with increased organic loading } \\
\text { or decreased HRT. } \\
\text { - Effective in combined leachate and domestic wastewater } \\
\text { treatment }\end{array}$ & $\begin{array}{l}\text { (Necz } \\
\text { aj et } \\
\text { al., } \\
\text { 2008) }\end{array}$ \\
\hline Mature & $\begin{array}{l}\text { F/M: 0.005, OLR: } 0.12 \\
\mathrm{~kg} / \mathrm{m}^{3} \mathrm{~d}, \text { NLR: } 0.132 \\
\mathrm{~kg} / \mathrm{m}^{3} \mathrm{~d}, 3600 \mathrm{~L} / \mathrm{h}\end{array}$ & $\begin{array}{l}\text { Powdered } \\
\text { Activated } \\
\text { Carbon } \\
\text { SBR (PAC- } \\
\text { SBR) } \\
\end{array}$ & 1.2 & 8 & $3 . .34$ & & $\begin{array}{l}\mathrm{NH}_{4}^{+}: 89.91 \\
\text { COD: } 78.75 \\
\text { Color: } 65.36 \\
\text { TDS: } 49.33\end{array}$ & $\begin{array}{l}\text { - The PAC-SBRs has shown good efficiency, improved sludge } \\
\text { characteristics and outstanding energy savings from aeration }\end{array}$ & $\begin{array}{l}\text { (Aziz, } \\
\text { Aziz, } \\
\text { et al., } \\
2011 b \\
\end{array}$ \\
\hline Mature & $\begin{array}{l}\text { pH: } 6.6-8.5, \mathrm{DO}, 0.05- \\
0.7 ; \mathrm{NH}_{4}^{+}-\mathrm{N}, 300-900 ; \\
\mathrm{COD}, 100 ; \\
\mathrm{MgSO}_{4} \cdot 7 \mathrm{H}_{2} \mathrm{O}, 58 \\
\mathrm{KH}_{2} \mathrm{PO}_{4}, 111 ; \\
\mathrm{CaCl}_{2} \cdot 6 \mathrm{H}_{2} \mathrm{O}, 170 \\
(\mathrm{mg} / \mathrm{L}), 30^{\circ} \mathrm{C}\end{array}$ & $\begin{array}{l}\text { Intermittently } \\
\text { Aerated } \\
\text { Sequencing } \\
\text { Batch Reactor } \\
\text { (IASBR) }\end{array}$ & 8 & 6 & 2.9 & & TN: 81.5 & $\begin{array}{l}\text { - The NOB genus Nitrospira was successfully curtailed during } \\
\text { the experimental cycle } \\
\text { - Methanogens may coexist with microorganisms that convert } \\
\text { aerobic and anaerobic nitrogen in partial nitritation-anammox } \\
\text { systems } \\
\text { - The genus Candidatus Nitrososphaera was enriched with } \\
\text { ammonium-oxidizing archaea (AOA) and significantly } \\
\text { contributed to partial nitritation in the PN-A stage. }\end{array}$ & $\begin{array}{l}\text { (Qiu } \\
\text { et al., } \\
\text { 2019) }\end{array}$ \\
\hline Mature & $\begin{array}{l}\text { pH: 7.8-8.2, COD/TN: } \\
1-4, \mathrm{C} / \mathrm{N}: 4, \mathrm{DO},<2 ; \\
\text { MLSS, 3000; nitrite, } \leq 3 \text {; } \\
\text { Nitrate, } \leq 3 ; \text { alkalinity, } \\
\text { 8000-11000 (mg/L), } \\
\text { COD, } 1-6 ; \text { ammonia, }\end{array}$ & SBR & 10 & 24 & & & TN: 98 & $\begin{array}{l}\text { - Glycogen accumulating organisms (GAOs) were responsible } \\
\text { for the enhanced nitrogen removal } \\
\text { - Microorganisms were able to store polyhydroxybutyrate } \\
\text { (PHB) and glycogen as electron donors during the anaerobic } \\
\text { stage for endogenous denitritation }\end{array}$ & $\begin{array}{l}\text { (Miao } \\
\text { et al., } \\
\text { 2015) }\end{array}$ \\
\hline
\end{tabular}




\begin{tabular}{|c|c|c|c|c|c|c|c|c|c|}
\hline & $\begin{array}{l}1.2-2(\mathrm{~g} / \mathrm{L}) ; 25^{\circ} \mathrm{C}, 100 \\
\mathrm{~L} / \mathrm{h}\end{array}$ & & & & & & & & \\
\hline Mature & $\begin{array}{l}\text { pH: } \sim 7.2, \mathrm{BOD}_{5} / \mathrm{COD}, \\
0.07, \text { conductivity }(\mathrm{EC}) \\
13,750 \mu \mathrm{S} / \mathrm{cm}, \mathrm{BOD}_{5}, 38 ; \\
\mathrm{COD}, 538 ; \mathrm{TOC}, 297 \\
(\mathrm{mg} / \mathrm{L}), 80 \mathrm{~L} / \mathrm{h}\end{array}$ & $\begin{array}{l}\text { Sequencing } \\
\text { Batch Internal } \\
\text { Micro- } \\
\text { Electrolysis } \\
\text { Reactor (SIME) }\end{array}$ & 0.7 & & & & $\begin{array}{l}\text { COD: } 86.1 \\
\text { Color: } 95.3 \\
\text { BOD: } 57.9 \\
\text { Heavy metals: } \\
>80\end{array}$ & $\begin{array}{l}\text { - Significantly improved the leachate } \mathrm{BOD}_{5} / \mathrm{COD} \text { ratio } \\
\text { - Automated operation, potential biological compatibility and } \\
\text { high degradation rate }\end{array}$ & $\begin{array}{l}\text { (Ying, } \\
\text { Xu, et } \\
\text { al., } \\
\text { 2012) }\end{array}$ \\
\hline Mature & $\begin{array}{l}\text { pH: } 8.25 \text {, Color: } 1690 \\
\text { Pt.Co, } \mathrm{BOD}_{5}, 269 ; \mathrm{COD} \text {, } \\
1301 ; \mathrm{NH}_{3}-\mathrm{N}, 532 ; \\
\text { phenol, } 1.69(\mathrm{mg} / \mathrm{L}) \\
28.7^{\circ} \mathrm{C}, 104.4 \mathrm{~L} / \mathrm{h}\end{array}$ & $\begin{array}{l}\text { Powdered } \\
\text { ZELIAC-SBR } \\
\text { (PZ-SBR) }\end{array}$ & 1.2 & 24 & & & $\begin{array}{l}\text { Phenols: } 61.32 \\
\text { Color: } 84.11 \\
\mathrm{NH}_{3}-\mathrm{N}: 99.01 \\
\text { COD: } 72.84\end{array}$ & $\begin{array}{l}\text { - Powdered ZELIAC-SBR showed higher performance in } \\
\text { contaminant removal }\end{array}$ & $\begin{array}{l}\text { (Mojir } \\
\text { i et } \\
\text { al., } \\
\text { 2014) }\end{array}$ \\
\hline Mature & $\begin{array}{l}\text { pH: } 7.87, \mathrm{BOD}_{5} / \mathrm{COD}: \\
0.22,3627 \mathrm{Pt} . \mathrm{Co}, \mathrm{NH}_{3^{-}} \\
\mathrm{N}, 600 ; \mathrm{COD}, 1655 ; \\
\mathrm{BOD}, 373(\mathrm{mg} / \mathrm{L}), 28.7 \\
{ }^{\circ} \mathrm{C}, 120 \mathrm{~L} / \mathrm{h}\end{array}$ & $\begin{array}{l}\text { Powdered } \\
\text { Activated } \\
\text { Carbon (PAC- } \\
\text { SBR) }\end{array}$ & 1.2 & 8 & & & $\begin{array}{l}\text { COD: } 64.1 \\
\text { Color: } 71.2 \\
\mathrm{NH}_{3}-\mathrm{N}: 81.4 \\
\text { TDS: } 1.33\end{array}$ & $\begin{array}{l}\text { - Sufficient and efficient for treating low biodegradable landfill } \\
\text { leachate at low aeration rate as low as } 0.5 \mathrm{~L} / \mathrm{min}\end{array}$ & $\begin{array}{l}\text { Aziz, } \\
\text { Aziz, } \\
\text { Yusof } \\
\text { f, et } \\
\text { al., } \\
\text { 2011) }\end{array}$ \\
\hline Mature & $\begin{array}{l}\text { pH: } 8.08 \\
\mathrm{COD}, 2055 ; \\
\mathrm{NH}_{4}-\mathrm{N}, 1199(\mathrm{mg} / \mathrm{L}) \\
20 \pm 1^{\circ} \mathrm{C}, 1.2 \mathrm{~L} / \mathrm{h}\end{array}$ & SBR & 24 & 24 & & $20-25$ & $\begin{array}{l}\text { COD: } 20 \\
\text { Nitrogen: } 95\end{array}$ & $\begin{array}{l}\text { - Nitrite path efficacy for nitrogen suppression optimization in } \\
\text { leachate treatment was confirmed. } \\
\text { - Inhibition of the nitrite oxidizing organisms was observed } \\
\text { - Significant saving of external COD addition was achieved. }\end{array}$ & $\begin{array}{l}\text { (Spag } \\
\text { ni \& } \\
\text { Marsil } \\
\text { i- } \\
\text { Libell } \\
\text { i, } \\
\text { 2009) }\end{array}$ \\
\hline Mature & $\begin{array}{l}\text { pH: } 7.5 \pm 0.2, \mathrm{DO}, 0.2- \\
0.5 ; \mathrm{NH}_{4}-\mathrm{N}, 2000 ; \mathrm{COD}, \\
2200 ; \mathrm{MLSS}, 3500-4200 \\
(\mathrm{mg} / \mathrm{L}), 25-35^{\circ} \mathrm{C}, 100 \\
\mathrm{~L} / \mathrm{h}\end{array}$ & $\begin{array}{l}\text { Anaerobic } \\
\text { Ammonium } \\
\text { Oxidation } \\
\text { (Anammox) } \\
\text { SBR }\end{array}$ & 13 & 5 & 0.75 & & TN: 90 & $\begin{array}{l}\text { - Increased anammox gene ratio } \\
\text { - Achieved nitritation with } \mathrm{NO}_{2} / \mathrm{NOx} \text { ratio }>95 \% \text {. } \\
\text { - Adjusted continuous filling mode in SBRana significantly } \\
\text { minimised the effects of nitrite inhibition }\end{array}$ & $\begin{array}{l}\text { (Miao } \\
\text { et al., } \\
\text { 2014) }\end{array}$ \\
\hline Intermediate & $\begin{array}{l}\text { pH:7.6-8.2, } \mathrm{NH}_{4}{ }^{+}-\mathrm{N} \\
\text { 1025-1327; TN, 1346- } \\
\text { 1854; COD, 6430-9372; } \\
\text { MLSS, 9200; MLVSS, } \\
7000(\mathrm{mg} / \mathrm{L}), 25 \pm 1^{\circ} \mathrm{C}\end{array}$ & SBRS & 10 & 24 & & $25-30$ & $\begin{array}{l}\mathrm{NH}_{4}{ }^{+}-\mathrm{N}: 99.7 \\
\text { TN: } 98.3 \\
\text { COD: } 89.8\end{array}$ & $\begin{array}{l}\text { - Utilization of PHAs and glycogen as electron donor in the } \\
\text { post-anoxic denitrification had been proved } \\
\text { - Enrichment of GAOs may be attributed to steady nitrogen } \\
\text { removal performance via post-denitrification without external } \\
\text { carbon addition }\end{array}$ & $\begin{array}{l}\text { (Z. M. } \\
\text { Li et } \\
\text { al., } \\
\text { 2014) }\end{array}$ \\
\hline Mature & $\begin{array}{l}\text { pH: } 8 \pm 0.2, \mathrm{TN}, 3000 \pm \\
100 ; \mathrm{COD}, 3000 \pm 100 \\
\text { MLSS, } 3900 \pm 100 \\
(\mathrm{mg} / \mathrm{L}), 35^{\circ} \mathrm{C}, 100 \mathrm{~L} / \mathrm{h}\end{array}$ & $\begin{array}{l}\text { Sequencing } \\
\text { Biofilm Batch } \\
\text { Reactor (SBBR) }\end{array}$ & 10 & 24 & & & TN: 95 & $\begin{array}{l}\text { - Anammox and heterotrophic bacteria could coexist due to } \\
\text { biofilm } \\
\text { - The Biofilm anammox-gene ratios increased due to the } \\
\text { biofilm protection. }\end{array}$ & $\begin{array}{l}\text { (Miao } \\
\text { et al., } \\
\text { 2016) }\end{array}$ \\
\hline Mature & $\begin{array}{l}\text { pH: } 7.8, \mathrm{DO}, \geq 2 ; \mathrm{NH}_{4}^{+}- \\
\text {N, 3096; } \mathrm{HCO}_{3} ; 12960 ; \\
\mathrm{COD}, 2770 ; \mathrm{MLSS}, \\
3200(\mathrm{mg} / \mathrm{L}), 28-32^{\circ} \mathrm{C}\end{array}$ & $\begin{array}{l}\text { Partial } \\
\text { Nitritation-SBR } \\
\text { (PN-SBR) }\end{array}$ & 40 & 73 & 3.85 & 122 & COD: 11 & $\begin{array}{l}\text { - Stability achieved after } 75 \text { days of operation } \\
\text { - Free Ammonia (FA) concentration of up to } 500 \mathrm{mg} / \mathrm{L} \mathrm{NH}_{3}-\mathrm{N} \\
\text { did not have an adverse effect on } \mathrm{AOB} \text { but completely } \\
\text { suppressed NOB growth }\end{array}$ & $\begin{array}{l}\text { (Nhat } \\
\text { et al., } \\
\text { 2017) }\end{array}$ \\
\hline Intermediate & $\begin{array}{l}\text { pH: 8.4-8.7, DO, <1; } \\
\text { COD, } 1040-4870 ; \text { AN, } \\
905-1650(\mathrm{mg} / \mathrm{L})\end{array}$ & $\begin{array}{l}\text { Modified Rice } \\
\text { Husk (MRH)- } \\
\text { SBR and (PAC- } \\
\text { SBR) }\end{array}$ & 10 & 24 & & 20 & $\begin{array}{l}\text { COD: } 81 \\
\mathrm{NH}_{4}^{+}-\mathrm{N}: 87\end{array}$ & $\begin{array}{l}\text { - The improved performance of MRH in removal of COD and } \\
\text { AN compared to PAC is attributed to presence of attached } \\
\text { growth biomass on MRH owing to the use of much larger } \\
\text { sizes of MRH compared to PAC }\end{array}$ & $\begin{array}{l}\text { (P. E. } \\
\text { Lim, } \\
\text { Lim, } \\
\text { Seng, } \\
\&\end{array}$ \\
\hline
\end{tabular}




\begin{tabular}{|c|c|c|c|c|c|c|c|c|c|}
\hline & & & & & & & & & $\begin{array}{l}\text { Noor, } \\
2010)\end{array}$ \\
\hline Mature & $\begin{array}{l}\text { pH: } 8.05, \mathrm{BOD}_{5}, 301 \\
\mathrm{COD}, 1759 ; \mathrm{NH}_{4}-\mathrm{N} \\
1061(\mathrm{mg} / \mathrm{L}), 20^{\circ} \mathrm{C}, 1.2 \\
\mathrm{~L} / \mathrm{h}\end{array}$ & SBR & 24 & 24 & 8 & & $\begin{array}{l}\mathrm{NO}_{2}^{-}: 98 \\
\text { Nitrogen: } 95 \\
\text { COD: } 60\end{array}$ & $\begin{array}{l}\text { - Control system that relies on conceptions of artificial } \\
\text { intelligence requiring external COD to accomplish the } \\
\text { denitrification was engineered to operate the SBR resulting in } \\
\text { significant improvement of the process }\end{array}$ & $\begin{array}{l}\text { (Spag } \\
\text { ni et } \\
\text { al., } \\
2008)\end{array}$ \\
\hline Mature & $\begin{array}{l}\mathrm{pH}: 7.6, \mathrm{BOD}_{5} / \mathrm{COD}: \\
0.38, \mathrm{BOD}_{5} / \mathrm{N}: 4.04, \mathrm{DO} \\
4 ; \mathrm{COD}, 1596 ; \mathrm{BOD}_{5} \\
622 ; \mathrm{NH}_{4}-\mathrm{N}, 141(\mathrm{mg} / \mathrm{L}) \\
25^{\circ} \mathrm{C}\end{array}$ & SBR & 6 & 24 & $2-12$ & $8-80$ & $\begin{array}{l}\text { COD: } 76.2 \\
\mathrm{NH}_{4}-\mathrm{N}: 82\end{array}$ & $\begin{array}{l}\text { SBR reactors with a short filling period, longer HRT and SRT } \\
\text { appeared to be the most sensitive and favorable, whereas } \\
\text { reactors with the filling over the reaction period proved to be } \\
\text { more resistant. }\end{array}$ & $\begin{array}{l}\text { Klim } \\
\text { iuk \& } \\
\text { Kulik } \\
\text { owska } \\
\text { 2005) }\end{array}$ \\
\hline Mature & $\begin{array}{l}\text { pH: 6-9, color: } 3444 \\
\text { Pt.Co, BOD } / \text { COD: } 0.20 \\
\text { COD, } 1516 ; \mathrm{NH}_{3}-\mathrm{N} \\
603 ; \mathrm{BOD}_{5}, 337 ; \mathrm{MLSS} \\
9893(\mathrm{mg} / \mathrm{L}), 26 \pm 2{ }^{\circ} \mathrm{C}\end{array}$ & $\begin{array}{l}\text { Powdered } \\
\text { Activated } \\
\text { Carbon (PAC) } \\
\text { augmented SBR }\end{array}$ & 2 & 24 & 10 & & $\begin{array}{l}\mathrm{NH}_{3}-\mathrm{N}: 99.66 \\
\text { Color: } 84.06 \\
\text { COD: } 69.78\end{array}$ & $\begin{array}{l}\text { - The removal of organic substances was attributed to } \\
\text { biological as well as adsorption phenomenon } \\
\text { - PAC clearly improved SBR performance by exhibiting } \\
\text { energy savings, decreased SVI value, higher pollutant } \\
\text { removal capability and retained DO }\end{array}$ & $\begin{array}{l}\text { (Aziz, } \\
\text { Aziz, } \\
\text { et al., } \\
2011 \text { a } \\
\text { ) }\end{array}$ \\
\hline Intermediate & $\begin{array}{l}\mathrm{pH}: 8, \mathrm{DO}, 3 ; \mathrm{COD} \\
6500 ; \mathrm{NH}_{3}-\mathrm{N}, 1000 ; \\
\mathrm{BOD}_{5}, 4500 ; \mathrm{MLSS} \\
9230 ; \mathrm{MLVSS}, 7523 \\
(\mathrm{mg} / \mathrm{L}), 25 \pm 1^{\circ} \mathrm{C}\end{array}$ & $\begin{array}{l}\text { Sequencing } \\
\text { Batch } \\
\text { Biofilm Reactor } \\
\text { (SBBR) }\end{array}$ & 10 & 8 & & & $\begin{array}{l}\text { COD: } 83-88 \\
\text { TN: } 95-98\end{array}$ & $\begin{array}{l}\text { - The dominant bacterial communities present were AOB and } \\
\text { denitrifying bacteria with organic transformation capability } \\
\text { - } 89.66 \% \text { of the total bacteria were Bacteroidetes and } \\
\text { Proteobacteria }\end{array}$ & $\begin{array}{l}\text { (Yin } \\
\text { et al., } \\
2018)\end{array}$ \\
\hline Mature & $\begin{array}{l}\text { COD, 0.5-3.0; MLSS, } \\
\text { 3.03-5.95; MLVSS, } \\
2.09-4.12(\mathrm{~g} / \mathrm{L}), 90 \mathrm{~L} / \mathrm{h}\end{array}$ & SBR & 7 & 48 & 2 & 6 & COD: 86.57 & $\begin{array}{l}\text { - SBR with activated sludge (resistant to potentially toxic } \\
\text { substrate) was an efficient, reliable and stable process for } \\
\text { organic matter degradation in leachate }\end{array}$ & $\begin{array}{l}\text { (Vuko } \\
\text { vic et } \\
\text { al., } \\
2012 \text { ) }\end{array}$ \\
\hline Mature & $\begin{array}{l}\text { pH: 7-8.6, DO, <0.1; } \\
\text { COD, 855-2850; BOD, } \\
30-360 ; \text { TN, 547-1391; } \\
\text { VSS, } 1000-1800(\mathrm{mg} / \mathrm{L}) \\
28-36{ }^{\circ} \mathrm{C}\end{array}$ & $\begin{array}{l}\text { Anammox } \\
\text { Sequencing } \\
\text { Batch Reactor }\end{array}$ & 20 & & 1 & $8-41$ & TN: 88 & $\begin{array}{l}\text { - NRR increases with the increase of NLR. However, the } \\
\text { higher NLR triggered accumulation of substrates and affected } \\
\text { the efficacy of anammox processes }\end{array}$ & $\begin{array}{l}\text { (Tom } \\
\text { aszew } \\
\text { ski, } \\
\text { Cema, } \\
\text { Tward } \\
\text { owski, } \\
\& \\
\text { Ziemb } \\
\text { inska- } \\
\text { Buczy } \\
\text { nska, } \\
\text { 2018) }\end{array}$ \\
\hline Mature & $\begin{array}{l}\mathrm{pH}: 7.1, \mathrm{DO}, 2 ; \mathrm{COD} \\
994 ; \mathrm{BOD}_{5}, 444 ; \mathrm{TP} \\
18.4 ; \mathrm{TKN}, 89.9(\mathrm{mg} / \mathrm{L}) \\
30 \pm 2{ }^{\circ} \mathrm{C}\end{array}$ & SBR & 10 & 24 & 2 & $60-80$ & $\begin{array}{l}\text { COD: } 86.7 \\
\text { TKN: } 96.9 \\
\text { TP: } 89.3\end{array}$ & $\begin{array}{l}\text { - Duration of the non-aerated cycle has limited impact on } \\
\text { output of the SBR. } \\
\text { - Increase in SRT reduced leachate TP removal efficiency }\end{array}$ & $\begin{array}{l}\text { (Fong } \\
\text { satitk } \\
\text { ul et } \\
\text { al., } \\
2008)\end{array}$ \\
\hline Mature & $\begin{array}{l}\mathrm{COD}, 2766 ; \mathrm{NH}_{4}-\mathrm{N} \\
1895 ; \mathrm{BOD}_{5}, 485 ; \mathrm{TSS} \\
56.1 ; \mathrm{TN}, 2045 ; \mathrm{TP}, 16.3 \\
(\mathrm{mg} / \mathrm{L}), 20 \pm 1{ }^{\circ} \mathrm{C}\end{array}$ & & 8 & $12-24$ & & $70-92$ & $\begin{array}{l}\mathrm{NH}_{4}-\mathrm{N}: 99.91 \\
\text { TN: } 93 \\
\text { TP: } 80 \\
\text { COD: } 90\end{array}$ & $\begin{array}{l}\text { - The structure, operation and diversity of the AOB and NOB } \\
\text { populations appear to be important components needed for } \\
\text { potential partial nitrification application }\end{array}$ & $\begin{array}{l}\text { (Fudal } \\
\text { a- } \\
\text { Ksiaz } \\
\text { ek et }\end{array}$ \\
\hline
\end{tabular}




\begin{tabular}{|c|c|c|c|c|c|c|c|c|c|}
\hline & & & & & & & & $\begin{array}{l}\text { - Reduced external carbon source could be attributed to PN } \\
\text { process }\end{array}$ & $\begin{array}{l}\text { al., } \\
\text { 2014) }\end{array}$ \\
\hline Young & $\begin{array}{l}\text { BOD } / \text { COD: } 0.68 \mathrm{pH}: 7- \\
8.33 \text {, DO, } 2-4 ; \text { COD, } \\
\text { 10500; MLSS, } 2200 ; \\
\text { MLVSS, } 1540(\mathrm{mg} / \mathrm{L}) \\
32-34^{\circ} \mathrm{C}, 3600 \mathrm{~L} / \mathrm{h}\end{array}$ & SBR & 2 & 24 & 4.1 & & COD: 81 & $\begin{array}{l}\text { Alkali pre-treatment reduces the toxicity effect of heavy } \\
\text { metals on microorganism activities, improves sludge } \\
\text { characteristics, high COD removal rate, and increase } \\
\text { respiration rate }\end{array}$ & $\begin{array}{l}\text { (Ganji } \\
\text { an et } \\
\text { al., } \\
\text { 2018) }\end{array}$ \\
\hline Young & $\begin{array}{l}\text { EC: } 33.5(\mathrm{~ms} / \mathrm{cm}) \mathrm{pH} \\
\text { 4.4, OLR: } 0.25-6.3 \mathrm{~g} \\
\text { COD/L.d, COD, } 95.5 \\
\text { BOD }_{5}, 2.3 ; \mathrm{TKN}, 55.2 \\
\text { TP, } 0.28(\mathrm{~g} / \mathrm{L})\end{array}$ & SBR & 2 & 24 & & & $\begin{array}{l}\text { COD: } 92.45 \\
\text { BOD }: 96 \\
\text { TN: } 73.6 \\
\text { TP: } 66.5\end{array}$ & $\begin{array}{l}\text { - Satisfactory system performance at low loading rates with } \\
\text { decreased removal rate by increasing OLR and decreasing } \\
\text { HRT } \\
\text { - The hazardous compounds and metals present caused } \\
\text { disruption in nitrogen and phosphorus elimination }\end{array}$ & $\begin{array}{l}\text { (Hash } \\
\text { emi, } \\
\text { Zad, } \\
\text { Derak } \\
\text { hshan, } \\
\& \\
\text { Ebrah } \\
\text { imi, } \\
\text { 2017) }\end{array}$ \\
\hline Intermediate & $\begin{array}{l}\text { pH: 8.5, COD, 6914; TN, } \\
\text { 2024.98; } \mathrm{NH}_{4}-\mathrm{N}, \\
1863.69(\mathrm{mg} / \mathrm{L}), 24.5-27 \\
{ }^{\circ} \mathrm{C}\end{array}$ & SBR & 70 & 12 & & $60-80$ & $\begin{array}{l}\text { COD: } 55 \\
\text { TN: } 60\end{array}$ & $\begin{array}{l}\text { - Control of total air flow (TAF)/influent loading rate (ILR) } \\
\text { ratio could prevent nitrate formation } \\
\text { - Effluent pH can be an indicator of PN performance. }\end{array}$ & $\begin{array}{l}\text { (Y. H. } \\
\text { Xu, } \\
\text { Zhou, } \\
\& \text { Li, } \\
2020)\end{array}$ \\
\hline Young & $\begin{array}{l}\text { pH: 7.6, DO, }>4 ; \text { COD, } \\
\text { 16000; MLSS, 4000; } \\
\text { MLVSS, } 3250(\mathrm{mg} / \mathrm{L}) \\
25 \pm 2{ }^{\circ} \mathrm{C}\end{array}$ & $\begin{array}{l}\text { Aerobic } \\
\text { Sequencing } \\
\text { Batch Reactor } \\
\text { (ASBR) }\end{array}$ & 2 & 24 & 2 & & COD: 90 & $\begin{array}{l}\text { - System's tolerance to organic shock loading was high. } \\
\text { - COD removal rate decreased at low HRT }\end{array}$ & $\begin{array}{l}\text { (Mous } \\
\text { avi et } \\
\text { al., } \\
\text { 2015) }\end{array}$ \\
\hline Intermediate & $\begin{array}{l}\text { BOD } / \text { COD: } 0.25, \mathrm{DO},> \\
5 ; \mathrm{COD}_{7} 727 ; \mathrm{BOD}_{5}, \\
183 ; \mathrm{NH}_{4}-\mathrm{N}, 365 ; \mathrm{TN}, \\
417 ; \mathrm{MLVSS}_{4} 4480 \\
(\mathrm{mg} / \mathrm{L})\end{array}$ & SBR & 350000 & 24 & 11.67 & 11.67 & $\begin{array}{l}\text { BOD }: 86 \\
\text { TKN: } 93.58 \\
\text { COD: } 41.93 \\
\text { TN: } 71 \\
\text { NH}_{4}-\mathrm{N}: 85\end{array}$ & $\begin{array}{l}\text { - Low VSS/SS ratio improved sludge settleability } \\
\text { - Addition of external carbon source improved the } \\
\text { denitrification process. However, high concentrations of } \mathrm{NO}_{3}{ }^{-} \\
\text {-N were found in the SBR effluent }\end{array}$ & $\begin{array}{l}\text { (Rem } \\
\text { mas et } \\
\text { al., } \\
\text { 2018) }\end{array}$ \\
\hline Young & $\begin{array}{l}\text { pH: 7.3, DO, >2.5 COD, } \\
38769.2 ; \text { BOD }_{5}, 27300 ; \\
\text { TKN, 2571.5; TP, 73.7; } \\
\text { MLSS, 5000 (mg/L) }\end{array}$ & $\begin{array}{l}\text { IAnA- } \\
\text { BioGACSBR }\end{array}$ & 3.6 & & 12 & & $\begin{array}{l}\text { BOD }_{5}: 99 \\
\text { TKN: } 78.9 \\
\text { COD: } 98.54\end{array}$ & $\begin{array}{l}\text { - Under optimum zone, in the Integrated Anaerobic- } \\
\text { Aerobic/Biogranular Activated Carbon SBR (IAnA- } \\
\text { BioGACSBR) leachate can be safely discharged safely into } \\
\text { municipal wastewater system }\end{array}$ & $\begin{array}{l}\text { (Pirsa } \\
\text { heb et } \\
\text { al., } \\
\text { 2017) }\end{array}$ \\
\hline Young & $\begin{array}{l}\text { pH: 7.5, COD, 30500; } \\
\text { TN, 8050; BOD, } 11500 \\
(\mathrm{mg} / \mathrm{L})\end{array}$ & $\begin{array}{l}\text { Anaerobic } \\
\text { Sequencing } \\
\text { Batch Reactors } \\
\text { (ASBR) }\end{array}$ & & & & & COD: 82 & $\begin{array}{l}\text { - Greater reactor output in terms of COD removal efficiencies } \\
\text { and increased development of biogas was directly linked to } \\
\text { the transfer of organic matter from leachate to dissolved } \\
\text { phase by ultrasonic pretreatment }\end{array}$ & $\begin{array}{l}\text { (Yari } \\
\text { mtepe } \\
\& \mathrm{Oz} \\
2018)\end{array}$ \\
\hline Mature & $\begin{array}{l}\text { DO, 0.6; COD, } 2400 \\
(\mathrm{mg} / \mathrm{L}), \mathrm{pH}: 8.0,25-30 \\
{ }^{\circ} \mathrm{C}\end{array}$ & $\begin{array}{l}\text { Sequencing } \\
\text { Batch Biofilm } \\
\text { Reactor (SBBR) }\end{array}$ & 3 & 8 & & & $\begin{array}{l}\mathrm{NH}_{4}^{+}-\mathrm{N}:>97 \\
\mathrm{COD}:>86\end{array}$ & $\begin{array}{l}\text { - Coexistence of nitrifiers, denitrifiers, AOB and NOB were } \\
\text { detected }\end{array}$ & $\begin{array}{l}\text { (Y. } \\
\text { Xiao } \\
\text { et al., } \\
\text { 2009) }\end{array}$ \\
\hline Intermediate & $\begin{array}{l}\text { COD/N/P: } 100: 6: 2, \mathrm{pH}: \\
7.2-8, \mathrm{SVI}_{30}:>40 \mathrm{~mL} / \mathrm{g} \\
\text { DO, 3-4; COD, } 4000 ; \\
\text { BOD }_{5}, 70 ; \mathrm{NH}_{4}-\mathrm{N}, 290 ; \\
\text { MLVSS, >2000 }(\mathrm{mg} / \mathrm{L})\end{array}$ & SBR & 3 & 24 & 6 & 30 & $\begin{array}{l}\mathrm{NH}_{4}-\mathrm{N}: 93 \\
\mathrm{NO}_{3}-\mathrm{N}: 83 \\
\mathrm{COD}: 85 \\
\mathrm{PO}_{4}{ }^{3}-\mathrm{P}: 80 \\
\text { Turbidity: } 83\end{array}$ & $\begin{array}{l}\text { - Kinetic parameters for microbial growth implied that biomass } \\
\text { growth was not inhibited by } 20 \% \text { leachate. } \\
\text { - System can be used as a pretreatment step for direct leachate } \\
\text { co-treatment }\end{array}$ & $\begin{array}{l}\text { (Ranj } \\
\text { an et } \\
\text { al., } \\
\text { 2016) }\end{array}$ \\
\hline
\end{tabular}




\begin{tabular}{|c|c|c|c|c|c|c|c|c|c|}
\hline Mature & $\begin{array}{l}\text { pH: } 8.3-8.5, \mathrm{DO}>4 ; \\
\mathrm{COD}, 2960 ; \mathrm{NH}_{4}-\mathrm{N} \\
1617 ; \mathrm{BOD}_{5}, 54 ; \\
\text { MLVSS, } 3000(\mathrm{mg} / \mathrm{L})\end{array}$ & $\begin{array}{l}\text { Moving Bed } \\
\text { Sequencing } \\
\text { Batch Reactor } \\
\text { (MBSBR) }\end{array}$ & 3.3 & 24 & & 30 & TN: 80 & $\begin{array}{l}\text { - At higher leachate volumetric ratio, Intermittent Aeration- } \\
\text { MBSBR with polyurethane (PU) media is the most preferred } \\
\text { operational strategy for nitrogen removal }\end{array}$ & $\begin{array}{l}\text { (Tan } \\
\text { et al., } \\
\text { 2016) }\end{array}$ \\
\hline Mature & $\begin{array}{l}\text { SVI: } 170-180 \mathrm{~mL} / \mathrm{g}, \mathrm{pH}: \\
8.0, \mathrm{DO}, 0.5-1 ; \mathrm{COD}, \\
1615 ; \mathrm{BOD}_{5}, 301 ; \mathrm{NH}_{4^{-}} \\
\mathrm{N}, 958 ; \mathrm{TKN}, 1082 \\
(\mathrm{mg} / \mathrm{L}), 20 \pm 1^{\circ} \mathrm{C}, 1.2 \\
\mathrm{~L} / \mathrm{h}\end{array}$ & & 24 & 24 & & 25 & $\begin{array}{l}\text { COD: } 60 \\
\mathrm{NO}_{3}-\mathrm{N}: 99\end{array}$ & $\begin{array}{l}\text { - Small quantity of phosphorus present in leachate has been } \\
\text { reported to seriously crumble the nitrification process. } \\
\text { - Accumulation of nitrite results to incomplete denitrification } \\
\text { process } \\
\text { - Unstable nitritation and denitritation processes }\end{array}$ & $\begin{array}{l}\text { (Spag } \\
\text { ni et } \\
\text { al., } \\
\text { 2007) }\end{array}$ \\
\hline Mature & $\begin{array}{l}\mathrm{pH}: 8.5, \mathrm{COD}, 3600 ; \\
\mathrm{NH}_{4}-\mathrm{N}, 990 ; \mathrm{BOD}_{5}, 530 \\
\text { TKN, } 1100(\mathrm{mg} / \mathrm{L}), 18- \\
20{ }^{\circ} \mathrm{C}\end{array}$ & & & 24 & & & $\begin{array}{l}\text { COD: } 80 \\
\mathrm{NH}_{4}-\mathrm{N}: 82 \\
\text { BOD }_{5}: 99\end{array}$ & $\begin{array}{l}\text { - Superior economic efficiency, possibility of treating influent } \\
\text { with a significantly larger share of leachate and considerably } \\
\text { increased biodegradability of mature landfill leachate. }\end{array}$ & $\begin{array}{l}\text { (Gros } \\
\text { ser et } \\
\text { al., } \\
\text { 2019) }\end{array}$ \\
\hline Mature & $\begin{array}{l}\text { pH: 8.98, COD:N:P: } \\
\text { 100:10:1, COD, 2510; } \\
\mathrm{NH}_{4}-\mathrm{N}, 398.93 ; \text { BOD }_{5}, \\
\text { 12.55; } \mathrm{PO}_{4}{ }^{3}-\mathrm{P}, 154.44 ; \\
\text { phenols, } 185.67(\mathrm{mg} / \mathrm{L}) \\
23 \pm 2{ }^{\circ} \mathrm{C}\end{array}$ & & 9 & 48 & & & COD: 41 & $\begin{array}{l}\text { - Multifactorial analysis has identified the negative effect of } \\
\text { leachate on the structure, activity and operation of the } \\
\text { activated sludge }\end{array}$ & $\begin{array}{l}\text { (Mich } \\
\text { alska } \\
\text { et al., } \\
\text { 2019) }\end{array}$ \\
\hline Mature & $\begin{array}{l}\text { pH: } 8.5, \mathrm{C} / \mathrm{N}: 3-5 ; \mathrm{Cd}, 1- \\
27 ; \mathrm{DO}, 0.1-1.0 ; \mathrm{MLSS} \\
6700 \pm 650 ; \mathrm{COD}, 1000 \\
\pm 65(\mathrm{mg} / \mathrm{L}), 23 \pm 2{ }^{\circ} \mathrm{C} \\
12 \mathrm{~L} / \mathrm{h}\end{array}$ & SBR & 5 & 8 & 0.67 & $20 \pm 2$ & Cd: 99 & $\begin{array}{l}\text { - Cd ion toxicity under high concentrations decreased the } \\
\text { activity of microorganisms even though some were adsorbed } \\
\text { by microbial communities. } \\
\text { - AOB and NOB were able to tolerate and function well under } \\
\text { concentrations }<5 \mathrm{mg} / \mathrm{L} \text { of } \mathrm{Cd}\end{array}$ & $\begin{array}{l}\text { (L. Q. } \\
\text { Zhang } \\
\text {, Fan, } \\
\text { Nguy } \\
\text { en, Li, } \\
\text { \& } \\
\text { Rodri } \\
\text { gues, } \\
\text { 2019) }\end{array}$ \\
\hline Intermediate & $\begin{array}{l}\text { pH: 7.4, C:N:P: } 100: 5: 1, \\
\text { F/M: } 0.10, \text { EC: } 5.13 \\
\text { mS/cm, DO, 5; COD, } \\
5821 ; \mathrm{NH}_{4}-\mathrm{N}, 241 ; \mathrm{VSS} \\
4000(\mathrm{mg} / \mathrm{L}), 20 \pm 1{ }^{\circ} \mathrm{C}\end{array}$ & SBR & 4.5 & 24 & 7.4 & & $\begin{array}{l}\text { COD: } 90 \\
\mathrm{NH}_{4}-\mathrm{N}: 80.8\end{array}$ & $\begin{array}{l}\text { - Biomass activity is not affected by reasonable leachate } \\
\text { volume in the SBR } \\
\text { - The existence of higher life forms and moderate abundance of } \\
\text { filamentous bacteria was confirmed by microscopic } \\
\text { observations }\end{array}$ & $\begin{array}{l}\text { (Capo } \\
\text { dici et } \\
\text { al., } \\
\text { 2014) }\end{array}$ \\
\hline
\end{tabular}




\subsection{Combined treatment technologies for leachate treatment}

SBR coupled with a membrane bioreactor (MBR) was used to treat young leachate as shown in Table 7. Findings revealed that sludge escapes from the SBR unit whenever the process is disturbed resulting to high concentrations of suspended solids, $\mathrm{BOD}_{7}$, and phosphorus (N. Laitinen et al., 2006). SBR can be enhanced by the addition of plastic media into the reactor through coagulation to increase the specific surface area of the reactor (Yong et al., 2018). In an integrated treatment system coupling SBR, GAC adsorption and aeration corrosive cell-Fenton (ACF), almost all of the carboxylic acids and protein substances were biodegraded in SBR, while leachate aromaticity was increased after SBR treatment (Bu et al., 2010). Sequencing internal micro-electrolysis reactor (IME) reactor was more efficient and faster than conventional electrolysis treatments (Ying, Peng, et al., 2012). In the SBR, Fenton Oxidation, Coagulation, and Biological Aerated Filtering (BAF) combined system, SBR was instrumental in the elimination of organic contaminants, while coagulation and fenton oxidation progressively reduced organic load and improved biodegradability. Coagulation was accomplished with low organic contaminants and high turbidity removals, and BAF removed low molecular weight fractions (Wu et al., 2011). A study by (Mojiri et al., 2017) revealed that SBR is ineffective in color removal from leachate with low biodegradability. However, adding composite adsorbent remarkably improves the removal. Ozonation process is effective in improving the BOD/COD ratio. Magnesium Ammonium Phosphate (MAP) Precipitation increases $\mathrm{C} / \mathrm{N}$ ratio by decreasing $\mathrm{NH}_{4}-\mathrm{N}$ concentration. Thus, high concentration of $\mathrm{Cl}_{2}$ after pretreatment with MAP will adversely affect the microbiological function of the successor SBR system (M. Chen, He, Yi, \& Yang, 2010). Attaching a trickling filter (TF) to an SBR system, the mean concentration of $\mathrm{NO}_{3}$ in effluents of the mature leachate increased owing to activities of nitrifying microorganisms (Aluko \& Sridhar, 2013). Bio-effluents from a sequencing batch biofilm reactor (SBBR) were further degraded by the subsequent electro-Fenton process. This results from the good correlation that exist between the absorbance of leachate at $254 \mathrm{~nm}\left(\mathrm{UV}_{254}\right)$ and $\mathrm{COD} / \mathrm{TOC}\left(\mathrm{D}\right.$. B. Zhang et al., 2014). The use of $\mathrm{Al}_{2}\left(\mathrm{SO}_{4}\right)_{3}$ as a coagulant in SBR + Coagulation-Settling process resulted to shorter reaction time, with effluent becoming cleaner and more visible (Trabelsi et al., 2013). Other treatment combinations include: SBR with continuous systems, UASB, photocatalysis, chemical precipitation, vertical flow constructed wetland, electrochemical process, AOP, moving bed biofilm reactor, high-rate algae pond, acidogenic co-fermentation, Integrated Fixed Film Activated Sludge (IFAS), zero-valent iron column, membrane filtration system, anaerobic baffle reactor, and sand filter.

\subsection{Effect of operational configurations, strategies, processes, materials and parameters for improved system efficiency}

\subsection{Effect of environmental and operational parameters on SBR system}

Several useful environmental and operational parameters have been successfully applied for leachate treatment in the past few decades (Ye et al., 2009). There is a definitive relationship between treatment efficiency and these parameter as they highly influence the performance of the SBR system. These can be ascertained by observing their influence on biological dephosphatation, nitrification and denitrification, impact on the microbial community structure and population, granulation, toxicity, biofilm formation, substrate storage and utilization (Liao, Droppo, Leppard, \& Liss, 2006). They also help in understanding floc structure, properties, and mechanisms of bioflocculation. Several parameters have been discussed to highlight their individual effects in an SBR system.

\footnotetext{
4.1.1 Aeration

Aeration plays a significant role in aerobic sludge granulation (Menezes et al., 2019). Slow aeration rate in SBR system could reduce the $\mathrm{NO}_{\mathrm{x}}{ }^{-}\left(\mathrm{NO}_{2}{ }^{-}\right.$and $\left.\mathrm{NO}_{3}{ }^{-}\right)$concentration, which reduces the carbon demand for denitrifying bacteria and leads to more carbon sources available for denitrification process. The oxygen-limited condition could improve wastewater biodegradability and reduce toxicity of refractory compounds, thereby further sustaining the dominant growth of nitrifying bacteria and denitrifying bacteria in SND process. Faster aerobic granulation results from high aeration rate as stated in literature. Also, to preserve the stability of aerobic granules, it is desirable to provide inhibiting overgrowth of filamentous bacteria appropriate hydraulic sharpening power. However, it has some disadvantages: high cost resulting from energy consumption, failure in TN removal, destruction of anaerobic conditions leading to low phosphorus removal etc. Attempts have been made to regulate the high aeration rate, but failed as the long-term stability enjoyed by aerobic granules were lost due to the changes in shear forces, nitrification was inhibited due to limited oxygen available. Reducing the aeration period has been identified as the best aeration regulatory measure ( $\mathrm{J}$. W. Lim, Lim, \& Seng, 2012).
} 
Table 7. Removal efficiencies for Integrated leachate treatment technologies

\begin{tabular}{|c|c|c|c|c|}
\hline $\begin{array}{l}\text { Leachate Treatment } \\
\text { System }\end{array}$ & Materials & Influent characteristics & Removal efficiency (\%) & Ref. \\
\hline $\begin{array}{l}\text { SBR + membrane } \\
\text { bioreactor }(\mathrm{MBR})\end{array}$ & $\begin{array}{l}\text { ZeeWeed® } 10(\text { ZW10) and } 500 \text { (ZW500) membrane } \\
\text { units }\end{array}$ & $\begin{array}{l}\mathrm{SS}, 475 ; \mathrm{BOD}_{7}, 1240 ; \text { Total Phosphorus (TP), 10; } \\
\mathrm{NH}_{4}^{+}-\mathrm{N}, 210(\mathrm{mg} / \mathrm{L})\end{array}$ & SS: $89, \mathrm{NH}_{4}{ }^{+}-\mathrm{N}: 99.5, \mathrm{BOD}_{7}: 94, \mathrm{TP}: 82$ & $\begin{array}{l}\text { (N. } \\
\text { Laitinen } \\
\text { et al., } \\
\text { 2006) }\end{array}$ \\
\hline SBR + Coagulation & $\begin{array}{l}\text { Coagulant: } 630.39 \mathrm{~g} / \mathrm{mole} \text { of Aluminium Sulphate } \\
\left(\mathrm{Al}_{2}\left(\mathrm{SO}_{4}\right)_{3} \cdot 16 \mathrm{H}_{2} \mathrm{O}\right)\end{array}$ & $\mathrm{BOD}_{5} / \mathrm{COD}: 0.17-0.24, \mathrm{MLVSS}, 2000-4000 \mathrm{mg} / \mathrm{L}$ & $\begin{array}{l}\text { COD: } 84.89, \mathrm{NH}_{3}-\mathrm{N}: 94.25, \mathrm{TSS}: 91.82, \\
\text { Color: } 85, \mathrm{Ag}: 50, \mathrm{As}: 34.8, \mathrm{Ba}: 87.2, \mathrm{Fe}: \\
\text { 62.9, Cd: } 81, \mathrm{Cu}: 95.3, \mathrm{Mn}: 22.9, \mathrm{Ni}: 41.3 \text {, } \\
\text { Pd: } 95, \mathrm{Se}: 100, \mathrm{Zn}: 41.2\end{array}$ & $\begin{array}{l}\text { (Yong et } \\
\text { al., 2018) }\end{array}$ \\
\hline $\begin{array}{l}\text { SBR + aeration } \\
\text { corrosive cell-Fenton } \\
(\mathrm{ACF})+\text { granular } \\
\text { activated carbon (GAC) } \\
\text { adsorption }\end{array}$ & $\begin{array}{l}\text { ACF reactor }(0.6 \mathrm{~L}, \varnothing 50 \mathrm{~mm} \times 310 \mathrm{~mm}) \text {, mixture of } \\
\text { iron scraps, GAC adsorption reactor }(0.28 \mathrm{~L}, \varnothing 36 \\
\mathrm{mm} \times 300 \mathrm{~mm}) .\end{array}$ & $\begin{array}{l}\mathrm{BOD}_{5} / \mathrm{COD}: 0.46, \text { organic loading } \\
\text { rate: } 1.7 \mathrm{kgCOD} / \mathrm{m}^{3} / \mathrm{d}, \mathrm{MLSS}, 4400 ; \text { MLVSS, } 2800 ; \\
\mathrm{COD}, 4200 ; \\
\mathrm{BOD}_{5}, 1940 ; \mathrm{DOC}, 1330(\mathrm{mg} / \mathrm{L})\end{array}$ & COD: 97.2, DOC: 98.7, BOD $5: 99.1$ & $\begin{array}{l}\text { (Bu et al. } \\
2010)\end{array}$ \\
\hline $\begin{array}{l}\text { SBR + internal micro- } \\
\text { electrolysis (IME) }\end{array}$ & $\begin{array}{l}\text { Custom-designed columnar reactor }(2.0 \mathrm{~L}, \emptyset 8 \mathrm{~cm} \\
\times 60 \mathrm{~cm}), \mathrm{GAC} \text {, and scrap cast iron }\end{array}$ & $\begin{array}{l}\text { pH: 7.2, EC: } 13750 \mu \mathrm{S} / \mathrm{cm} \text {, color: } 64 \text { Pt.Co, } \\
\text { BOD, 38; COD, } 538(\mathrm{mg} / \mathrm{L})\end{array}$ & $\begin{array}{l}\text { COD: 86.1, BOD: 57.9, Color: 95.3, EC: } \\
57.6\end{array}$ & $\begin{array}{l}\text { (Ying, } \\
\text { Peng, et } \\
\text { al., 2012) }\end{array}$ \\
\hline $\begin{array}{l}\text { SBR }+ \text { Coagulation }+ \\
\text { Fenton Oxidation }+ \\
\text { Biological Aerated } \\
\text { Filtering }(\text { BAF }) \\
\end{array}$ & & $\begin{array}{l}\text { pH: 7.83, color: } 2000 \text { Pt.Co, EC: } 18.6 \mathrm{mS} / \mathrm{cm} \text {, } \\
\text { turbidity: } 1670 \mathrm{NTU} \text { COD, 6722; BOD } 5,672 ; \\
\mathrm{CaCO}_{3}, 8314 ; \mathrm{NH}_{4}-\mathrm{N}, 850 ; \text { Total phosphorus (TP), } \\
\text { 8.3; SS, } 108(\mathrm{mg} / \mathrm{L})\end{array}$ & $\begin{array}{l}\text { COD: 98.4, Turbidity: 99.2, TP: 99.3, SS: } \\
\text { 91.8, } \mathrm{NH}_{4}-\mathrm{N}: \text { 99.3, Color: 99.6, BOD }: 99.1\end{array}$ & $\begin{array}{l}\text { (Wu et } \\
\text { al., 2011) }\end{array}$ \\
\hline $\begin{array}{l}\text { Electro-ozonation }+ \\
\text { composite adsorbent } \\
\text { augmented SBR }\end{array}$ & $\begin{array}{l}\text { Powdered BAZLASC (composite adsorbent), } \\
\text { Electro-ozonation reactor }(3.5 \mathrm{~L}, \varnothing 10 \mathrm{~mm} \times 50 \mathrm{~mm} \text { ), } \\
\mathrm{Ti}^{\mathrm{RuO}} \mathrm{Ru}_{2}-\mathrm{IrO}_{2}, 18 \mathrm{~cm} \times 8 \mathrm{~cm}\end{array}$ & $\begin{array}{l}\text { pH: 7.3, voltage: } 9 \text { V, color: } 2113 \text { (Pt. Co), current: } \\
4 \text { A, COD, 3018; Ni, } 29.67(\mathrm{mg} / \mathrm{L})\end{array}$ & $\begin{array}{l}\text { SBR } \\
\text { COD: } 64.8 \text {, Color: } 90.4, \text { Ni: } 52.9 \\
\text { PB-SBR } \\
\text { COD: } 88.2 \text {, Color: } 96.1, \text { Ni: } 73.4\end{array}$ & $\begin{array}{l}\text { (Mojiri et } \\
\text { al., 2017) }\end{array}$ \\
\hline $\begin{array}{l}\text { Magnesium Ammonium } \\
\text { Phosphate (MAP) } \\
\text { Precipitation }+ \text { SBR }\end{array}$ & $\begin{array}{l}\mathrm{Mg}^{2+} \text { and } \mathrm{PO}_{4}{ }^{3-} \text { at a weight ratio of } \mathrm{Mg}^{2+}: \mathrm{PO}_{4}{ }^{3}: \mathrm{NH}_{4}{ }^{+}- \\
\mathrm{N}=1.1: 1.1: 1.0\end{array}$ & $\begin{array}{l}\text { pH: 7.5-8.1, MLSS, 7000; } \\
\mathrm{COD}, 12000 ; \mathrm{BOD}_{5}, 4250 ; \mathrm{NH}_{4}-\mathrm{N}, 2800 ; \mathrm{TP}, 13.8 ; \\
\mathrm{CaCO}_{3}, 11120(\mathrm{mg} / \mathrm{L})\end{array}$ & $\mathrm{NH}_{4}-\mathrm{N}: 98$ & $\begin{array}{l}\text { (M. Chen } \\
\text { et al., } \\
2010)\end{array}$ \\
\hline $\begin{array}{l}\text { SBR + Trickling filter } \\
(\mathrm{TF})\end{array}$ & $\begin{array}{l}\text { Fine sand }(0.3-2.0 \mathrm{~mm}), \text { coarse sand }(2-14 \mathrm{~mm}) \text { and } \\
\text { coarse gravel }(14-35 \mathrm{~mm})\end{array}$ & $\begin{array}{l}\text { EC: } 4515 \mu \mathrm{s} / \mathrm{cm}, \mathrm{DO}, 1.9 ; \mathrm{SS}, 197.5 ; \mathrm{BOD}_{5}, 712 ; \\
\mathrm{COD}, 3365 ; \mathrm{NH}_{3}, 610.9 ; \mathrm{NO}_{3}, 1.06(\mathrm{mg} / \mathrm{L})\end{array}$ & $\begin{array}{l}\text { SS: } 62.28, \mathrm{BOD}_{5}: 84.06, \mathrm{NH}_{4}-\mathrm{N}: 64.83 \\
\text { COD: } 76.2\end{array}$ & $\begin{array}{l}\text { (Aluko \& } \\
\text { Sridhar, } \\
\text { 2013) }\end{array}$ \\
\hline $\begin{array}{l}\text { Coagulation-Flocculation } \\
+ \text { SBR }\end{array}$ & Bittern, $\mathrm{FeCl}_{3}$ and $\mathrm{Al}_{2}\left(\mathrm{SO}_{4}\right)_{3}$ & $\begin{array}{l}\text { DO, 6-8; COD, 7760-11770; } \text { BOD }_{5}, 2760-3569 ; \\
\text { TN, 980-1160 (mg/L) }\end{array}$ & $\mathrm{BOD}_{5}: 89, \mathrm{COD}: 60, \mathrm{TN}: 72$ & $\begin{array}{l}\text { (El-Fadel } \\
\text { et al., } \\
2013)\end{array}$ \\
\hline $\begin{array}{l}\text { Sequencing batch biofilm } \\
\text { reactor (SBBR) + Electro- } \\
\text { Fenton process }\end{array}$ & $\begin{array}{l}\text { Biological filter (volcanic rock filler material) with } \\
\text { an average porosity of } 80 \%\end{array}$ & $\begin{array}{l}\text { pH: 8.55, DO, 1-2; COD, 2495; } \text { BOD }_{5}, 243 ; \mathrm{NH}_{4}-\mathrm{N}, \\
\text { 1680; TN, 1808; MLVSS, 3300-3800 (mg/L) }\end{array}$ & COD: 21.6, $\mathrm{BOD}_{5}: 54.7, \mathrm{NH}_{4}-\mathrm{N}: 56.1$ & $\begin{array}{l}\text { (D. B. } \\
\text { Zhang et } \\
\text { al., 2014) }\end{array}$ \\
\hline $\begin{array}{l}\text { SBR + Coagulation- } \\
\text { Settling process }\end{array}$ & $\begin{array}{l}\mathrm{Al}_{2}\left(\mathrm{SO}_{4}\right)_{3} \\
\mathrm{FeCl}_{3}\end{array}$ & $\begin{array}{l}\text { EC: } 35 \mathrm{mS} / \mathrm{cm}, \mathrm{pH}: 8.32, \mathrm{DO}, 3.0 ; \mathrm{COD}, 20800 ; \\
\mathrm{NH}_{4}-\mathrm{N}, 2645 \text { (mg/L) }\end{array}$ & COD: 99, $\mathrm{NH}_{4}-\mathrm{N}: 85$ & $\begin{array}{l}\text { (Trabelsi } \\
\text { et al., } \\
\text { 2013) }\end{array}$ \\
\hline $\begin{array}{l}\text { SBR+ electrochemical } \\
\text { oxidation process (EOP) }\end{array}$ & $\begin{array}{l}\text { Oxide-coated titanium anode }\left(\mathrm{Ti} / \mathrm{TiO}_{2}-\mathrm{IrO}_{2}\right) \\
\text { Carbon steel cathodes }\end{array}$ & DO, 2.0; MLSS, $3000(\mathrm{mg} / \mathrm{L})$ & $\mathrm{NH}_{4}-\mathrm{N}: 98, \mathrm{COD}: 58, \mathrm{TOC}: 62$ & $\begin{array}{l}\text { (Chu et } \\
\text { al., 2008) }\end{array}$ \\
\hline
\end{tabular}


The aeration phase of a conventional SBR system can be modified giving rise to an intermittent aeration sequencing batch reactor IASBR. Intermittent aeration in SBR is a strategy where aeration and non-aeration periods are alternately repeated to create aerobic and anoxic conditions, efficient nitrogen removal from wastewater. It can be operated by modifying the react phase of system cycle, i.e alternating aeration and mixing under imprecise control conditions of DO, pH, and temperature (Zheng, Zhang, Liu, \& Lei, 2018). Intermittent aeration can be a useful strategy for $\mathrm{N}_{2} \mathrm{O}$ mitigation during wastewater treatment and an alternative to keep low concentrations of oxygen (Menezes et al., 2019). The main advantages of applying intermittent aeration in SBR include enhanced nitrogen removal and decreased the operating costs due to a reduction in the continuous supply of oxygen and the quantity of energy source required for the resulting denitrification phase. Nevertheless, the denitrification process may be interrupted where there is insufficient availability of carbon source as an electron donor.

Stable and long-term partial nitrification can be achieved in an IASBR, coupled with good nitrite accumulation efficiency. IASBR results in reduced oxygen demand and organic substrate for ammonia removal and denitrification respectively. Unlike the SBR, The IASBRs showed higher nitrification and denitrification rates, obtaining $88-99 \% \mathrm{NH}_{4}{ }^{+} \mathrm{N}$ and $77-79 \% \mathrm{TN}$ removal. The concentration of denitrification-based bacteria in IASBRs was greater than in SBR (Sheng, Liu, Song, Chen, \& Tomoki, 2017). Interestingly, the more aerobic/anoxic switch times in an IASBR, the higher were abundance of denitrification-related bacteria. In a related study by (J. W. Lim et al., 2012) reported that operating an IASBR system yielded up to $91 \%$ and $92 \%$ removal efficiencies for TKN and $\mathrm{NH}_{4}{ }^{+}-\mathrm{N}$ respectively.

\subsubsection{Agitation}

Agitation rate plays an important role in the provision of good mixing conditions, solubilization of suspended organic material and improving mass transfer. These properties lead to increasing substrate consumption rate which may subsequently reduce the total cycle duration. In an SBR system, agitation can be provided by mechanical stirring, recirculation of biogas and liquid recirculation. Increasing the resistance to mass transfer obviously altered the dynamics of volatile acid production and use, thereby allowing the mechanism to reach various apparent steady states when the agitation rate decreased. The study (Penteado et al., 2011), thus concluded that systemic agitation not only improved the global efficiency of organic matter removal but also influenced the production and consumption of volatile acids. In another study, it was found that the output of biogas could not be sufficient to enhance the turbulence needed to minimize both the incidence of potential stagnant zones and the resistance to mass transfer. Thus, an anaerobic sequencing batch reactor (ASBR) was developed where agitation was accomplished by recirculation of the effluent by means of a diaphragm pump. Authors finalized that it is possible to utilize effluent recirculation as a means of agitation. To verify the efficiency of recirculation, optimum recirculation velocity for an ASBR system used in wastewater treatment was evaluated. Findings revealed that the system was restricted by mass transfer when running at lower speeds. Higher velocities, however, may decrease microbial activity because of too much shearing, which could damage the flocs contained in the biomass and cause rupture of the granules, leading to poor solid separation (Maurina et al., 2014).

\subsubsection{Superficial gas velocity}

The function of superficial gas velocity (SGV) is not just to shape the structure of aerobic granules but also to influence the efficiency of biological removal. Size and density of aerobic granular sludge are dependent on the superficial gas velocity. High superficial gas velocity (HSGV) typically results in the formation of sludge granules with small volume, compact structure, large internal mass transfer resistance and good settling that are easily discharged because of their small size, leading to loss of sludge and decreased reactor efficiency. In compact sludge particles, microbes located deep within the granules receive an insufficient nutrient supply. On the contrary, low superficial gas velocity (LSGV) has been reported to provide better pollutant degradation performance than more compact granules despite the low density, poorer settling performance, and low mass transfer resistance of the produced granules (He, Zhang, Zhang, \& Wang, 2017). The low mass resistance can aid microbes resided within granules with sufficient energy supply. LSGV is said to be an efficient and effective capacity for concurrent nitrogen, carbon and phosphorus elimination during operation. Its activity ratio is said to be better than the seed sludge.

\subsubsection{Shock loads}

SBRs could sometimes be fed an excess of particulate organics, that might require additional hydraulic retention time (HRT) to process, while a temporary increase in wastewater volume or the sudden break down of one of the reactors may impose a hydraulic overload on the biological process. In dealing with complex wastewater as leachate, it is essential to study reactor performance during shock loading conditions. The sudden change of influent concentration, or organic shock loading, can eventually disrupt the treatment system performance. Stress to the bioreactor due to shock loading can be normalized by adding excess of simple carbon source, reducing OLR by half initial value and/or 
sludge replacement prior to further experimentation (Kulkarni, 2012). During shock loading, the experimental recovery period is mostly greater than the theoretical period. This could be due to the inhibitory effects of toxic compounds present in the wastewater (Mizzouri \& Shaaban, 2013). The common types of shock loads are:

- Hydraulic shock load: Hydraulic shocks are usually created by decreasing the HRT of overloaded reactors. It is a fact that during the hydraulic shock, the limiting factor to the reaction rate is the rate of mass transfer of substrate into the biomass.

- Organic shock load: these can be generated by applying different concentrations of COD at variable time intervals. The differences in the COD concentrations can be created by the dilution of reactor wastewater. The shock load could be twice or thrice the normal organic load.

- Toxic shock load: this is the application of chemical solutions to increase contaminant concentration in the reactor mix above the threshold limit for the activated sludge process.

- Combined shock load: here, two or three of the aforementioned shocks with different stages of intensity for single or double cycles are simultaneously introduced to the reactor, and then its efficiency to treat wastewater evaluated (Mizzouri \& Shaaban, 2013).

\subsubsection{Hydraulic Retention Time (HRT)}

HRT may be considered as a measure of the average period of time wastewater remained in a bioreactor system. The HRT for an SBR system is given by:

$$
H R T=\frac{\left(t_{\mathrm{C}}\right)}{V_{\mathrm{F}} / V_{\mathrm{T}}} \frac{1}{24}
$$

Where, $V_{F}$ in Eq. (1) above is the wastewater loaded quantity and extracted effluent for a cycle, $V_{T}$ is the reactor's total working volume and $t_{C}$ is the total cycle time (Thakur, Mall, \& Srivastava, 2013).

HRT is an essential property during biological wastewater and hydrogen production process due to its of its substrate uptake efficiency and ability to determine the economics of hydrogen production process (Shariati et al., 2011). The design of HRT imposes a significant effect on the infrastructure and operational costs in an engineered bioreactor. HRT can be reduced by the introduction of membrane modules. The change of membrane modules can further lead to a decrease in HRT by increasing the permeability and an operating flux. Presence of DO and long hunger period during the treatment process can lead to incomplete denitrification (Scheumann \& Kraume, 2009). HRT decrease in the range 8-24 h, led to an increase in biomass concentration which did not improve removal efficiency (S. N. Xu, Wu, \& Hu, 2014). However, it contributed to the increase in the sludge particle size range, concentration of SMPc, apparent viscosity and a subsequent rise in membrane fouling rates. Higher MLSS at lower HRT is consistent with earlier published findings and can be due to the rise in OLR (Shariati et al., 2011). Similarly, the specific nitrite and ammonium oxidation rates, specific nitrate reduction and oxygen uptake rates, sludge volume index increases with reduction in HRT from 17-9 h. However, the diversity indices of microbial community decreased from 2.692.39. HRT increase mostly required under low temperature causes endogenous decay rate, reduced biomass concentration, specific biomass growth rate and yield. During hydrogen production in an ASBR, longer HRT would provoke development of non-hydrogen producing bacteria while shorter HRTs lowers $\mathrm{H}_{2}$ yield. This contradicts the findings reported by (Abd Nasir et al., 2019) where low HRT significantly boost the performance of the ASBR in producing biomethane. Continuous shortening of the HRT can further deteriorate the system productivity by biomass washout of active bacteria and decrease in microbial population.

\subsubsection{Sludge retention time (SRT)}

SRT is a significant design and operating parameter for activated sludge processes used to control process parameters. These include: nitrification, effluent water quality, wasted sludge volume, oxygen demand and growing status (S. N. $\mathrm{Xu}$ et al., 2014). It represents the average amount of time that an organism spends within a bioreactor. To maintain an organism in a bioreactor, its net growth rate should be equal or more than the SRT. Thus, bioreactors with higher SRT should maintain higher diversity of bacterial community.

Mathematically, SRT can be determined using the following equation:

$$
S R T=\frac{V \times X_{\mathrm{r}}}{Q \times X_{\mathrm{e}}}
$$

where $V$ is the effective reactor volume; $Q$ is the volume of effluent per day; and $X_{r}$ and $X_{e}$ are the VSS concentration of the reactor and effluent, respectively (Sekine et al., 2018).

The SRT computed in Eq. (2) above can be controlled by daily wasting of activated sludge. The waste volume can be estimated with the equation:

$$
Q_{w}=\frac{V}{S R T}
$$


where: $Q_{w}$ in Eq. (3) is the wasting rate for suspended solids, $\mathrm{L} / \mathrm{d}$; SRT is the solids retention time, d; V is the reactor working volume, L (Esparza-Soto, Nunez-Hernandez, \& Fall, 2011).

SRT may be used for microbial community shift in BNR systems. With SRT increase, it took much longer time to attain high nitritation rates. Relatively short SRT will reduce nitrification start-up time. Nitrite accumulating rate (NAR) is mostly higher at shorter SRT. Operating an SBR at different SRTs can lead to diversity in floc morphology. Irregular sludge flocs morphology is usually found at low SRTs. Possible notable variation in the effluent SS level of is expected for different SRTs. The sludge's flocculating ability varies with respect to SRT. The better flocculating ability of sludge at higher SRTs are due to a far more hydrophobic and less negatively charged surface while irregular floc morphology is due to the restriction of both substrate and oxygen diffusion (Liao et al., 2006). Effluent treated at lower SRTs presented higher SS concentration and vice-versa. TSS and turbidity levels in lower SRTs are also said to be higher than that in longer SRTs. Dispersed growth has also been observed at lower SRTs from time to time.

\subsubsection{Cycle duration}

A cycle in SBR is mathematically represented by Eq. (4), where total cycle time $\left(t_{C}\right)$ is the summation of all these phases.

$t_{C}=t_{F}+t_{R}+t_{S}+t_{D}+t_{I}$

Where, $t_{F}$ is the fill time $(\mathrm{h}), t_{S}$ settle time $(\mathrm{h}), t_{R}$ react time $(\mathrm{h}), t_{I}$ idle time $(\mathrm{h})$ and $t_{D}$ decant time (h) (Thakur et al., 2013).

The effect of the cycle duration has been seldom investigated. It can be seen that the continuous reduction in cycle time contributed to an increase in the structure of biomass resulting from a more abundant organic fraction (Scheumann \& Kraume, 2009). At short cycle duration, increased P removal was experienced Which can be linked to a greater percentage of $\mathrm{N}$ being removed via nitrite pathway that makes biodegradable $\mathrm{C}$ more accessible for Enhanced Biological Phosphorus Removal (EBPR). But as the cycle duration is increased, the system experienced reduction in $\mathrm{P}$ removal efficiency because the demand for denitrification of biodegradable organic $\mathrm{C}$ rises with total nitrification (Ginige, Kayaalp, Cheng, Wylie, \& Kaksonen, 2013).

\subsubsection{Feeding}

Feed duratiom: has a greater effect than the $t_{F} / t_{C}$ ratio, because it is critical in determining feed strategy. Long feed times $\left(t_{F} / t_{C}>0.5\right)$ affects system performance linked to extra-cellular polymer synthesis, organic matter removal efficiency and settleability characteristics. Operating an SBR at low $\left(t_{F} / t_{C}\right)$ for higher loads, pollutant degradation efficiency decreased by $>25 \%$. (Bezerra et al., 2009) observed that longer feeding periods resulted in reduced volatile acid accumulation. Changes in feed length throughout the cycle alter the substrate gradients: systems with fast feed are distinguished by strong gradients as substrate gradients are less sharp in slow feed systems. It should be noted that, the presence or absence of substrate gradients in a reactor system can have major effects on substrate absorption, storage rates of the developed biomass and settleability (Dionisi, Majone, Levantesi, Bellani, \& Fuoco, 2006). Furthermore, systems with fast feed are characterized by superior settling features than slow-feed systems. This is true, though, even if filamentous microorganism has no role to play.

Feed strategy: The way the reactor is fed, i.e., pulse vs. continuous feeding modes. One of the most favorable approaches used to solve loading problems in batch mode systems is feed strategy modification. The feeding strategy impact on the substrate removal mechanism was much higher than on the microbial composition. Pulse and continuous feeding operate under conditions that favor internal storage and direct microbial growth. As reported by (Ciggin, Rossetti, Majone, \& Orhon, 2012), pulse vs. continuous feeding did not induce substantial change in the biomass dominant bacteria. The study also confirmed that acetate removal was much quicker under pulse feeding conditions than continuous feeding. Reactors operating at pulse feeding modes attained stability and higher efficiency for treating organic wastewater in a higher organic loading condition.

In terms of aeration, the performance of the unaerated fill reactor was better than that of the aerated fill reactor as filamentous bacteria is developed in the latter reactor. however, the bioactivity of the microorganisms could be inhibited due to the accumulation of contaminants during the unaerated fill period. Conclusively, SBR with aerated FILL had the advantage of being able to provide treatment at a higher organic loading rate.

\subsubsection{Mixed liquor suspended solids (MLSS)}

MLSS is the combination of certain amount of suspended solid mixed with incoming wastewater. MLSS concentration is a key operational variable for SBR technology that directly affects effluent quality. Thus, should be regularly monitored. MLSS is a highly complex parameter as high value results in sludge bulking making the treatment system less efficient due to the non-settled biomass within the effluent wastewater while low value leads to energy wasting with consequential effect of discharging poor effluent. $\mathrm{P}$ in wastewater can be significantly accumulated in MLSS but 
can be removed by sludge wasting. The effect of MLSS on simultaneous nitrification and denitrification in a SBR was investigated by (S. N. Xu et al., 2014). The average removal efficiencies of COD and TN increased from 93 and $68.21 \%$ to 97 and $74.20 \%$ as MLSS increases in MLSS from 3.5-4.0 to 7.5-8.0 g/L, respectively. Although $\mathrm{NH}_{4}{ }^{+}-\mathrm{N}$ removal efficiency decreased, SND efficiency significantly increased with the increase in MLSS. Batch tests suggested that there was a strong potential to apply high MLSS for treating wastewater containing high strength ammonia nitrogen. This contradicts the findings by (Alattabi, Harris, Alkhaddar, Ortoneda-Pedrola, \& Alzeyadi, 2019) where effluent quality significantly drops under high concentrations of MLSS. Other parameters not sufficiently discussed due to insufficient information from literature include: recirculation, idle time, volumetric exchange ratio (VER) ratio between substrate and biomass concentration, reactor geometric configuration and characteristics, organic loading rate etc.

\subsection{SBR processes for leachate treatment}

A number of modified approaches to biological nitrogen removal includes completely autotrophic nitrogen removal over nitrite (CANON), anaerobic ammonium oxidation (ANAMMOX), oxygen-limited autotrophic nitrificationdenitrification (OLAND), simultaneous nitrification and denitrification (SND) via nitrite, simultaneous nitrificationanammox-denitrification (SNAD), single reactor system for high activity ammonium removal over nitrite (SHARON) and deammonification (DEMON) (Arun, Manikandan, Pakshirajan, \& Pugazhenthi, 2019). These technologies as further discussed with their advantages and disadvantages in Table 8 have been used to economically treat wastewater heavily concentrated with ammonium and are suggested to reduce DO and organic carbon source requirements for nitrogen removal. They differ in the operating conditions and devices for controlling microbial communities which drive de-ammonification (Shao, Yang, Mohammed, \& Liu, 2018). Some of these mechanisms are impaired by the long start-up duration because of the AnAOB's slow growth rate that has a doubling time of 7-14 days.

\subsection{Strategies for SBR enhancement}

To intensively improve the conventional sequencing batch reactors (SBRs), different strategies have been developed. These strategies include: algal-bacterial symbiosis, quorum sensing, cometabolism, augmentation, biougmentation and granulation. Optimization algorithm are usually studied for these new strategies for better performance. Most of these strategies highlighted in Table 9 focus on feed distribution, biofilm formation and regulation, interactions among inter- and intra-species, transition of flocs to granules, mediating the production and component of EPS, rapid startup of the SBR reactor. Physicochemical forces (hydrodynamic force, gravity force, etc.) and biological forces (production of extracellular polymer, growth of bacteria clusters, etc.) play significant roles in these strategies (J. F. Wang et al., 2018). Additionally, they can accelerate the acclimation period for biological treatment systems, allow microbes to biodegrade a wide range of refractory organics and built a growing environment for functional dominant bacteria (Kuang et al., 2018). These bacteria could achieve good degradation of contaminant and its derivatives. According to literature, these strategies could improve microbial community sustenance, sludge properties, nitrifiers activity, biodiesel yield of aerobic granules, the production of well settling biomass with reasonable SVI, capacity of the system to withstand high toxic shocks and mitigate their effects, substantially reduce aeration requirements during treatment (Meng et al., 2019). They also have the potential to enhance enzymatic activity and granule cultivation, avoid biomass washout, accelerate the sedimentation process of cells, increase non-growth substrates elimination rate and allow simultaneous removal of contaminants Interestingly, these strategies pave way for SBR to be developed into a promising, sustainable and cost effective technology giving rise to less by-products (Y. C. Li, Zhou, Gong, Wang, \& He, 2016).

\subsection{Effects of materials for SBR enhancement}

The performance, microbial community, enzymatic activity and pollutant degradation rate of SBRs using different materials under short- and long-term exposures have widely been studied by researchers. The efficiency and effect of individual materials mentioned in Table 10 depends on the correlation between the material and wastewater type and condition. 


\subsubsection{Heavy metals}

The effect of heavy metals on PN in SBR have been studied for landfill leachate. The result proved that under high concentrations, activities of the activated sludge microorganisms is affected due to toxicity resulting to failure of the PN process (L. Q. Zhang et al., 2019). Heavy metals can greatly impact EPS formation and composition (A. H. Jagaba, Abubakar, Lawal, Latiff, \& Umaru, 2018; Z. C. Wang et al., 2014), as high concentration could inhibit the microbial activity and growth of heterotrophic microorganisms relating to the degradation of organic matter. However, slight concentrations are still required by microorganisms to provide nutrition for optimum microbial growth.

\subsubsection{Metabolic uncouplers}

The idea of metabolic uncoupling reduction is to dissociate the energy coupling between catabolism of organic substrates and anabolism of new sludge biomass. Thereby a part of energy extracted from catabolism of substrates is wasted through futile cycles, leading to less production of bacterial cell mass (J. Zhang, Tian, Zuo, Chen, \& Yin, 2013). The phenomenon of uncoupled metabolism may be carried out under abnormal conditions such as the presence of inhibitory compounds or some heavy metals. The use of uncouplers are to reduce sludge production, control microbial contamination and increase substrate removal efficiency (Ferrer-Polonio et al., 2019).

\subsubsection{Biofilters}

Biofilters with high filtering capacity are utilized in SBR to reduce sludge quantity as they entrap granules into pores created by packing the reactor with a fill material. Depending on the material property, effective separation of sludge and MLSS improvement can be achieved. However, some filters result to the build-up of sludge in the filter media during long term operation (Kiso et al., 2005).

\subsubsection{Membranes}

Membranes are a physical barrier to suspended solids that are larger than the membrane pore size. Sedimentation and decantation phases of a typical SBR cycle can be replaced by membrane filtration. These reduces the cycle length, removes coliform bacteria and SS, avoid the formation of byproducts, thus providing higher quality effluent (Arrojo et al., 2005). However, membrane fouling is still a problem which depend on factors to include membrane material type, property and composition. Thus, the use of emerging new materials with pressure control potential is another way to mitigate fouling. Studies revealed that membrane fouling can be mitigated by either optimizing membrane operating conditions or preparing antifouling membranes.

\subsubsection{Biofilm carriers}

Biofilms are assemblages of microbial populations embedded in an EPS matrix on carriers with a three-dimensional and more complex structure, in which different functional microbial communities are located in different spaces (Zhou $\& \mathrm{Xu}, 2019$ ). They are a convenient way to keep functional bacteria in water treatment systems (Al-dhawi, Kutty, Almahbashi, Noor, \& Jagaba). Biofilm performance is determined by thickness and density which are a function of adopted biofilm support media. Biofilm carriers can provide a suitable environment for simultaneous aerobic and anoxic metabolic activity. They are suitable for denitrification, shock resistant and most commonly less energy consumption (Gonzalez, Esplugas, Sans, Torres, \& Esplugas, 2009). They are characterized by smaller foot-print, higher HRT, high organic matter and nitrogen removal rate, less growth of excess biomass and require lower operational costs. Biofilm limitation during phosphorus removal is the efficient removal of phosphorus-rich biomass from the reactor and the mass transfer of DO (Zhan, Rodgers, \& O'Reilly, 2006).

\subsubsection{Adsorbents}

The presence of adsorbents in SBR systems provides an opportunity for organic materials removal from effluent via adsorbing on the adsorbents. Adsorbents could effectively reduce toxicity to nitrifiers, provide surface for microbe growth to form biofilm, rapid aerobic granulation and simultaneously enhance nitrogen removal (Almahbashi et al., 2020; D. Wei et al., 2013). Among the materials mentioned in Table 10, those with large adsorption capacity are most preferred as they exhibit strong selective adsorption ability to nutrients and metals present in the leachate. In addition, adsorbents can also mitigate membrane fouling. Different adsorption capacity might typically lead to different dynamic equilibrium (J. Chen et al., 2019). However, some adsorbents are limited by high price.

\subsubsection{Carbon source}

Carbon source are indispensable for both $\mathrm{N}$ and $\mathrm{P}$ removal processes. Denitrification process in an SBR system requires organic sources of carbon as donor of electrons. It is influenced by the nature and availability of electron donor (Jin et al., 2013). Table 10 listed different materials utilized as carbon sources. Depleting the major sources of organic carbon would negatively affect denitrification and microorganism growth, which finally result to partial 
nitrification (Y. Y. Wang, Peng, \& Stephenson, 2009). Contrarily, the use of excess electron donor leads to wastage of expensive electron source and increases effluent COD.

\subsubsection{Carbon nanotubes (CNTs)}

CNTs can be inevitably found in leachate, domestic sewage and industrial wastewater. Their potential biotoxicity has generated significant concern in recent times as it can have adverse effects on microbial growth and can induce oxidative stress and cytotoxicity in human cells (Ma et al., 2019). On the other hand, CNTs have strong hydrophilicity and polarity which can encourage their potential for high water and wastewater dispersion (M. C. Gao et al., 2019). They can be used when treating wastewater as adsorbent, composite, antimicrobial agent, catalyst carrier and filtering media. CNTs can gather with biofilm and activated sludge due to their high hydrophobicity. The antimicrobial property of CNTs can alter the performance of the bioreactor. Therefore, it is important to evaluate the possible impact of different CNTs on bioreactor efficiency

\subsubsection{Nanoparticles (NPs)}

Carbon-based NPs are extensively used and thus, their global production is continuously increasing. Metal oxide NPs discharged into the environment could ultimately enter biological wastewater treatment systems. They could inhibit the organic matter and phosphorus removals, nitrification and denitrification of bioreactors treating wastewater (S. Wang et al., 2017) through obvious toxicity to microorganism, algae, aquatic invertebrate, terrestrial invertebrate and human tissue cell. Due to their small size and large specific surface area, NPs exhibit optical, electrical, and chemical characteristics different from either their bulk or dissolved forms. Scientists have shown that large quantities of NPs can be adsorptively eliminated from wastewater during treatment. Depending on the type and property of NPs, the adsorbed ones could decrease microbial populations, disturb microbial diversity, reduce hazardous substances, adsorb heavy metals and lead to a reduction in efficiency. An important application of NPs is to utilize the electron-donating capacity of nanometals to stimulate microbial growth and activity. NPs exposure for long duration not only reduced the population of AOB, but also inhibits the activities of ammonia monooxygenase and nitrite oxidoreductase (Puay, Qiu, \& Ting, 2015). 
Table 8. SBR processes for leachate treatment

\begin{tabular}{|c|c|c|c|c|c|}
\hline Process & Acronym & Description & Advantage & Disadvantage & Ref. \\
\hline Biological nutrient removal & BNR & $\begin{array}{l}\text { It is a key factor in preventing eutrophication in } \\
\text { receiving water. BNR plants provide alternatively } \\
\text { oxic and anoxic conditions to achieve nitrification } \\
\text { and denitrification as the two processes involved. } \\
\text { Denitrification exclusively occurs under } \\
\text { facultative anaerobic or microaerophilic } \\
\text { conditions with the aid of microorganisms. } \\
\text { However, complete denitrification can be achieved } \\
\text { under high DOC. }\end{array}$ & $\begin{array}{l}\text { - The most economical, efficient } \\
\text { and sustainable technique for } \\
\text { nutrient control to meet rigorous } \\
\text { discharge } \\
\text { requirements }\end{array}$ & $\begin{array}{l}\text { - Affected by limited DO as } \\
\text { it encourages } \mathrm{N}_{2} \mathrm{O} \\
\text { generation in both } \\
\text { nitrifier and heterotrophic } \\
\text { denitrification processes. } \\
\text { - COD acts as a limiting } \\
\text { factor for phosphorus } \\
\text { release and } \\
\text { denitrification. }\end{array}$ & $\begin{array}{l}\text { (Hajsardar, } \\
\text { Borghei, } \\
\text { Hassani, \& } \\
\text { Takdastan, } \\
\text { 2016) } \\
\text { (Marin, } \\
\text { Caravelli, \& } \\
\text { Zaritzky, } \\
\text { 2016) }\end{array}$ \\
\hline $\begin{array}{l}\text { DEnitrifying AMmonium } \\
\text { OXidation }\end{array}$ & DEAMOX & $\begin{array}{l}\text { Involves the production of } \mathrm{NO}_{2}-\mathrm{N} \text { from } \\
\text { heterotrophic } \mathrm{NO}_{3}-\mathrm{N} \text { reduction by inoculated } \\
\text { partial-denitrification sludge. } \mathrm{NO}_{2}-\mathrm{N} \text { and } \mathrm{NH}_{4}^{+}-\mathrm{N} \\
\text { are then extracted by anammox bacteria in a single } \\
\text { reactor. }\end{array}$ & $\begin{array}{l}\text { - It offers an effective alternative } \\
\text { for the simultaneous removal of } \\
\text { nitrogen and } \mathrm{NO}_{3}-\mathrm{N}\end{array}$ & $\begin{array}{l}\text { - } \mathrm{NO}_{2}^{-}-\mathrm{N} \text { could be } \\
\text { aggregated without } \\
\text { difficult control. } \\
\text { - Increased risk of } \\
\text { complete denitrification. }\end{array}$ & $\begin{array}{l}\text { (Du, Cao, Li, } \\
\text { Wang, \& } \\
\text { Peng, 2017) }\end{array}$ \\
\hline $\begin{array}{l}\text { Enhanced biological } \\
\text { phosphorus removal. }\end{array}$ & EBPR & $\begin{array}{l}\text { It is a proven and popular method that works on } \\
\text { the principle of alternating aerobic and anaerobic } \\
\text { environments with feeding substrates in anaerobic } \\
\text { stage. Most of the EBPR processes are focused on } \\
\text { cultivations of suspended biomass. Application of } \\
\text { culture independent techniques has enabled the } \\
\text { tentative detection of certain bacterial populations } \\
\text { involved in EBPR activated sludge communities. } \\
\mathrm{K} \text { and Mg are absolutely required for successful } \\
\text { EBPR. }\end{array}$ & $\begin{array}{l}\text { - Economical and reliable option } \\
\text { that allow facilities to achieve } \\
\text { water quality objectives at the } \\
\text { same time reducing chemical } \\
\text { utilization and sludge generation }\end{array}$ & $\begin{array}{l}\text { - Difficulties in assuring } \\
\text { stable and reliable } \\
\text { operation. } \\
\text { - Require large reactor } \\
\text { volume. }\end{array}$ & $\begin{array}{l}\text { (Y. Liu, Lin, } \\
\text { \& Tay, 2005) } \\
\text { (Yazici \& } \\
\text { Kilic, 2016) }\end{array}$ \\
\hline $\begin{array}{l}\text { Anaerobic ammonium } \\
\text { oxidation }\end{array}$ & ANAMMOX & $\begin{array}{l}\text { It is an autotrophic nitrogen removal process } \\
\text { equivalent to the classical denitrification that } \\
\text { involves the oxidation of nitrite ammonium as } \\
\text { electron acceptor and nitrate and } \mathrm{N}_{2} \text { gas as } \\
\text { production. Able to consume ammonium and } \\
\text { nitrite under anaerobic conditions. It is most } \\
\text { effective for ammonium-containing wastewater } \\
\text { with low C/N ratios. Much influent organic matter } \\
\text { can be saved and used in anaerobic digestion to } \\
\text { produce methane and recover waste water } \\
\text { supplies. Technologies based on anammox work } \\
\text { under higher temperatures and nitrogen charges as } \\
\text { higher Anammox biomass are generally expected. } \\
\text { It is commonly coupled with partial nitrification } \\
\text { which gives the anammox bacteria nitrite. } \\
\text { Continuous nitrite production stability is essential. }\end{array}$ & $\begin{array}{l}\text { - Higher nitrogen removal rate } \\
\text { (NRR), lower operational cost and } \\
\text { less space requirement. } \\
\text { - Lower oxygen consumption and } \\
\text { sludge production. } \\
\text { - No external carbon sources } \\
\text { required. } \\
\text { - Less undesirable byproducts }\end{array}$ & $\begin{array}{l}\text { - Longer start-up due to } \\
\text { ANAMMOX bacteria } \\
\text { growth characteristics } \\
\text { - Vulnerable to several } \\
\text { specific inhibitors such } \\
\text { as DO, pH, organic } \\
\text { compounds, temperature } \\
\text { and nitrite. } \\
\text { - Difficulty of bacteria } \\
\text { enrichment. } \\
\text { - Stable source of } \mathrm{NO}_{2}^{-}-\mathrm{N} \\
\text { generation. }\end{array}$ & $\begin{array}{l}\text { (Q. Li et al., } \\
\text { 2018) } \\
\text { (L. Q. Zhang } \\
\text { et al., 2019) }\end{array}$ \\
\hline
\end{tabular}




\begin{tabular}{|c|c|c|c|c|c|}
\hline $\begin{array}{l}\text { Simultaneous nitrification } \\
\text { and denitrification }\end{array}$ & SND & $\begin{array}{l}\text { It is a process during nitrogen removal that favors } \\
\text { nitrification and denitrification at the same time } \\
\text { under identical overall operating conditions. This } \\
\text { could be accomplished either by nitrification on } \\
\text { the biofilm surface and by denitrification in the } \\
\text { innermost layers or by using aerobic granular } \\
\text { sludge. The key factors influencing process } \\
\text { performance are the floc size, C/N ratio and } \\
\text { oxygen concentration. Effectiveness can be } \\
\text { improved by optimizing the operating parameters. }\end{array}$ & $\begin{array}{l}\text { - Can easily be achieved in biofilm } \\
\text { reactors. } \\
\text { - Capable of removing several } \\
\text { organics and nitrogen. } \\
\text { - Save carbon source, reduce } \\
\text { energy consumption and sludge } \\
\text { yield. } \\
\text { - Reduce the operational period and } \\
\text { cut operating cost. }\end{array}$ & $\begin{array}{l}\text { - Difficult to achieve } \\
\text { optimal microbial } \\
\text { community } \\
\text { - Nitrite accumulation }(>1 \\
\mathrm{mg} / \mathrm{L}) \text { seems to trigger } \\
\mathrm{N}_{2} \mathrm{O} \text { production, and at } \\
\text { higher levels could also } \\
\text { inhibit the denitrification } \\
\text { rate. }\end{array}$ & $\begin{array}{l}\text { (Marin et al., } \\
\text { 2016; L. Q. } \\
\text { Zhang et al., } \\
\text { 2009; S. Y. } \\
\text { Zhang et al., } \\
2020 \text { ) }\end{array}$ \\
\hline $\begin{array}{l}\text { Anaerobic/aerobic/anoxic } \\
\text { process }\end{array}$ & $\mathrm{AOA}$ & $\begin{array}{l}\text { The characteristic of this process is transferring } \\
\text { part of the mixed anaerobic liquor to the post- } \\
\text { anoxic zone to provide the carbon source essential } \\
\text { for denitrification. The process based on EBPR } \\
\text { system includes an aerobic condition wherein the } \\
\text { terminal electron acceptor is produced by } \\
\text { nitrifying the bacteria before the anoxic condition. } \\
\text { The process allows for Nitrogen and phosphorus } \\
\text { extraction from single reactor tank with a } \\
\text { sequential batch operation. Can achieve SND, } \\
\text { aerobic phosphorus uptake and anoxic } \\
\text { denitrification through real-time control with the } \\
\text { aid of the multi-zone structure. }\end{array}$ & $\begin{array}{l}\text { - Simple process configuration and } \\
\text { excellent performance. } \\
\text { - Could improve the utilization } \\
\text { efficiency of carbon source and } \\
\text { improve overall TN removal. } \\
\text { - Has large anoxic/aerobic } \\
\text { phosphate uptake rate (PUR) } \\
\text { ratio. } \\
\text { - Allows denitrifying phosphate- } \\
\text { accumulating organisms } \\
\text { (DNPAOs) to take an active part } \\
\text { in simultaneous nitrogen and } \\
\text { phosphorus removal. }\end{array}$ & $\begin{array}{l}\text { - Optimal microbial } \\
\text { community can hardly } \\
\text { be reached by regulating } \\
\text { operation conditions. }\end{array}$ & $\begin{array}{l}\text { (F. Y. Chen, } \\
\text { Liu, Tay, \& } \\
\text { Ning, 2011) }\end{array}$ \\
\hline Partial nitritation/anammox & $\mathrm{PN} / \mathrm{A}$ & $\begin{array}{l}\text { Either inoculate an anammox reactor with } \\
\text { nitrifying biomass or directly inoculate biomass } \\
\text { from another PN-A device is the most widely used } \\
\text { techniques for starting the PN-A process. Its } \\
\text { stability is dependent on the controlled interaction } \\
\text { of aerobic ammonium-oxidizing bacteria/archaea } \\
\text { and anammox bacteria, and also NOB successful } \\
\text { inhibition. Heterotrophic denitrifiers coexist with } \\
\text { AOB, anammox bacteria and NOB. }\end{array}$ & $\begin{array}{l}\text { - The system is suitable to treat } \\
\text { ammonium } \\
\text { containing. } \\
\text { - It can save } 60 \% \text { aeration and } 100 \\
\% \text { organic carbon costs } \\
\text { - It also can save sludge production } \\
\text { handling and disposal costs }\end{array}$ & $\begin{array}{l}\text { - Lack of comprehensive } \\
\text { bacterial populations } \\
\text { analysis which reveals the } \\
\text { functional and } \\
\text { phylogenetic } \\
\text { characteristics of the } \\
\text { microbes during the } \\
\text { transition from partial } \\
\text { nitritation to PN-A }\end{array}$ & $\begin{array}{l}\text { (Langone et } \\
\text { al., 2014; Qiu } \\
\text { et al., 2019) }\end{array}$ \\
\hline $\begin{array}{l}\text { Simultaneous nitrification, } \\
\text { denitrification and } \\
\text { phosphorus removal }\end{array}$ & SNDPR & $\begin{array}{l}\text { is recommended to eliminate } \mathrm{N} \text { and } \mathrm{P} \text {. } \\
\text { Denitrifying polyphosphate accumulating } \\
\text { organisms (DPAOs) are the effective microbes } \\
\text { which perform } \mathrm{N} \text { and } \mathrm{P} \text { simultaneous removal } \\
\text { from wastewater in SNDPR systems. Aerobic } \\
\text { granules can be used for these systems and achieve } \\
\text { excellent removal efficiencies }\end{array}$ & - Low carbon and oxygen demand & $\begin{array}{l}\text { - No long-term stability } \\
\text { potential } \\
\text { - Declination for both } \\
\text { nitrification } \\
\text { denitrification rates and }\end{array}$ & $\begin{array}{l}\text { (C. Li, Liu, } \\
\text { Ma, Zheng, } \\
\text { \& Ni, 2019) }\end{array}$ \\
\hline $\begin{array}{l}\text { Single-reactor high } \\
\text { ammonia removal over } \\
\text { nitrite }\end{array}$ & SHARON & $\begin{array}{l}\text { This process enables the removal of ammonia via } \\
\text { the so-called over-nitrite route. It is adopted to } \\
\text { achieve the inhibition of NOB based on the careful } \\
\text { selection of a low SRT and a high operating } \\
\text { temperature }\left(35^{\circ} \mathrm{C}\right) \text {. The technique can be done in } \\
\text { a standard continuous stirred tank reactor and ideal }\end{array}$ & - Efficient and inexpensive & $\begin{array}{l}\text { - Large footprint, long } \\
\text { liquid-solid separation } \\
\text { times and a low PN } \\
\text { efficiency }\end{array}$ & $\begin{array}{l}\text { (Song et al., } \\
2013) \quad \text { (Shi, } \\
\text { Yu, Sun, \& } \\
\text { Huang, 2009) }\end{array}$ \\
\hline
\end{tabular}




\begin{tabular}{|c|c|c|c|c|c|}
\hline & & $\begin{array}{l}\text { for extracting nitrogen from the waste stream with } \\
\text { a high concentration of ammonium }(>0.5 \mathrm{~g} / \mathrm{L}) \text {. } \\
\text { Nitrite produced is proportional to the alkalinity- } \\
\text { to-ammonium ratio (AAR) in the influent. }\end{array}$ & & & \\
\hline $\begin{array}{l}\text { Simultaneous partial } \\
\text { nitrification, anaerobic } \\
\text { ammonium oxidation and } \\
\text { denitrification system }\end{array}$ & SNAD & $\begin{array}{l}\text { This is the anammox, partial nitrification } \\
\text { and denitrification reactions integration in a single } \\
\text { reactor to treat low } \mathrm{C} / \mathrm{N} \text { wastewater }\end{array}$ & $\begin{array}{l}\text { - The system is ideal for treating } \\
\text { wastewater with low COD levels } \\
\text { and high nitrogen dominated } \\
\text { contaminants. } \\
\text { - Could save up to } 100 \% \text { and } 63 \% \\
\text { organic carbon source and } \\
\text { aeration costs respectively. }\end{array}$ & & $\begin{array}{l}\text { (Daverey, } \\
\text { Chen, Dutta, } \\
\text { Huang, \& } \\
\text { Lin, 2015) }\end{array}$ \\
\hline $\begin{array}{l}\text { Simultaneous anammox } \\
\text { and denitrification }\end{array}$ & SAD & $\begin{array}{l}\text { Anammox bacteria are inoculated into the } \\
\text { conventional denitrification reactor. Returned } \\
\text { nitrate is reduced to nitrite by heterotrophic } \\
\text { bacteria. Nitrite is then interrupted by anammox } \\
\text { bacteria from heterotrophic bacteria and is reduced } \\
\text { to } \mathrm{N}_{2} \text {. SAD process can successfully remove } \\
\text { nitrogen from wastewater without the nitritation } \\
\text { process. }\end{array}$ & $\begin{array}{l}\text { - SAD is capable of removing } \\
\text { anammox produced Nitrate } \\
\text { - Inhibition of the anammox } \\
\text { activity by organic matter can be } \\
\text { moderated } \\
\text { - Left over ammonium can further } \\
\text { be oxidized to nitrate by } \\
\text { conventional nitrification with } \\
\text { less oxygen supply. }\end{array}$ & & $\begin{array}{l}\text { (Takekawa, } \\
\text { Park, Soda, \& } \\
\text { Ike, 2014) } \\
\text { (J. Li et al., } \\
\text { 2016) }\end{array}$ \\
\hline $\begin{array}{l}\text { Completely autotrophic } \\
\text { nitrogen removal over } \\
\text { nitrite }\end{array}$ & CANON & $\begin{array}{l}\text { It is the Anammox and } \mathrm{PN} \text { process integration } \\
\text { inside a single reactor. A mechanism where the } \\
\text { partial oxidation of } \mathrm{NH}_{4}{ }^{+}-\mathrm{N} \text { to } \mathrm{NO}_{2}-\mathrm{N} \text { by aerobic } \\
\mathrm{AOB} \text { and the bacteria that oxidise anaerobic } \\
\text { ammonium (AnAOB) convert the resulting } \mathrm{NO}_{2}- \\
\mathrm{N} \text { and the remaining } \mathrm{NH}_{4}^{+}-\mathrm{N} \text { to } \mathrm{N}_{2} \text {, such that } \\
\text { biological nitrogen removal can be achieved } \\
\text { without the need for organic carbon sources. } \\
\text { Adding trace of } \mathrm{N}_{2} \mathrm{H}_{4} \text { to the system could improve } \\
\text { the nitrogen removal performance }\end{array}$ & $\begin{array}{l}\text { - Cost-effective autotrophic } \\
\text { nitrogen removal alternative } \\
\text { Alternative efficient cost method } \\
\text { for autotrophic nitrogen } \\
\text { extraction. } \\
\text { - Yields very low sludge volume at } \\
\text { very less oxygen demand, with no } \\
\text { carbon source required }\end{array}$ & $\begin{array}{l}\text { - Start-up phase may cause } \\
\text { operational difficulties } \\
\text { and subsequently require } \\
\text { significant control. } \\
\text { - Difficulties associated } \\
\text { with cultivating sufficient } \\
\text { Anammox bacteria and } \\
\text { long start-up period }\end{array}$ & $\begin{array}{l}\text { (P. Y. Xiao, } \\
\text { Lu, Zhang, } \\
\text { Han, \& Yang, } \\
\text { 2015) } \\
\text { (Deng, } \\
\text { Zhang, Miao, } \\
\text { \& Hu, 2016) }\end{array}$ \\
\hline $\begin{array}{l}\text { Oxygen-limited autotrophic } \\
\text { nitrification/denitrification }\end{array}$ & OLAND & $\begin{array}{l}\text { It is a one-step anammox and PN combination. It } \\
\text { consumes } 100 \% \text { less organic carbon, } 60 \% \text { less } \\
\text { oxygen and produces about } 90 \% \text { less sludge } \\
\text { compared to nitrification/denitrification. }\end{array}$ & $\begin{array}{l}\text { - Decreased risk of AnAOB nitrite } \\
\text { inhibition, reduced cost of } \\
\text { investment and less complicated } \\
\text { process management }\end{array}$ & $\begin{array}{l}\text { - Challenging process start- } \\
\text { up }\end{array}$ & $\begin{array}{l}\text { (Schaubroeck } \\
\text { et al., 2012) }\end{array}$ \\
\hline $\begin{array}{l}\text { DEnitrifying AMmonium } \\
\text { OXidation }\end{array}$ & DEAMOX & $\begin{array}{l}\text { In this system, } \mathrm{NO}_{2}-\mathrm{N} \text { can be derived by } \\
\text { inoculated partial-denitrification sludge from } \\
\text { heterotrophic } \mathrm{NO}_{3}-\mathrm{N} \text { reduction, the } \mathrm{NO}_{2}-\mathrm{N} \text { and } \\
\mathrm{NH}_{4}{ }^{+}-\mathrm{N} \text { are then extracted in a single reactor by } \\
\text { anammox bacteria. }\end{array}$ & 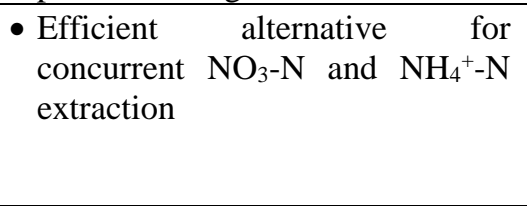 & $\begin{array}{l}\text { - Accumulation of } \mathrm{NO}_{2}-\mathrm{N} \text {. } \\
\text { - Using organic matter as } \\
\text { electron donor renders the } \\
\text { process less efficient }\end{array}$ & $\begin{array}{l}\text { (Du et al., } \\
2017)\end{array}$ \\
\hline
\end{tabular}


Table 9. Strategies for SBR enhancement (Kuang et al., 2018; S. Y. Li et al., 2019; Y. C. Li et al., 2016; Meng et al., 2019; Ni et al., 2009; J. F. Wang et al., 2018; L. Q. Zhang et al., 2019)

\begin{tabular}{|c|c|c|c|c|}
\hline Technique & Description & Materials & Advantages & Disadvantages \\
\hline $\begin{array}{l}\text { Algal-bacterial } \\
\text { symbiosis }\end{array}$ & $\begin{array}{l}\text { Algal-bacterial granules can be formed by bridging } \\
\text { filamentous bacteria with extracellular polymeric } \\
\text { substances through cell self-aggregation (EPS) in an } \\
\text { SBR exposed to natural sunlight. It is a promising } \\
\text { biotechnology for leachate, domestic and industrial } \\
\text { wastewater treatment. }\end{array}$ & Algal-bacterial granule & $\begin{array}{l}\text { - Simultaneous cultivation of high } \\
\text { value-added algal-bacterial } \\
\text { granules. } \\
\text { - Require less energy for organic } \\
\text { matter degradation. } \\
\text { - Produce sufficient } \mathrm{O}_{2} \text { required by } \\
\text { aerobic bacteria. }\end{array}$ & $\begin{array}{l}\text { - Separation and } \\
\text { harvesting algae from } \\
\text { the treated water is } \\
\text { challenging because of } \\
\text { poor settling, low } \\
\text { density and limited size } \\
\text { of microalgae cells }\end{array}$ \\
\hline $\begin{array}{l}\text { Quorum } \\
\text { sensing (QS) }\end{array}$ & $\begin{array}{l}\text { QS is a mechanism regulating interactions among } \\
\text { inter- and intra-species to mediate the expression of } \\
\text { relevant genes, coordinate the physiological } \\
\text { behavior of bacteria, and ultimately determine the } \\
\text { population structure. It mainly mediates EPS } \\
\text { production, biofilm or granule formation, } \\
\text { nitrification and denitrification. Production of QS } \\
\text { signal chemicals from biofilms induces bacteria } \\
\text { gene expression in suspensions to enable attached } \\
\text { growth rather than suspended growth }\end{array}$ & $\begin{array}{l}\text { Acylated homoserine lactones- } \\
\text { (AHLs). }\end{array}$ & $\begin{array}{l}\text { - Plays an essential part in } \\
\text { controlling the existence of } \\
\text { biofilms } \\
\text { - Perform nitrogen shortcut } \\
\text { technologies offering significant } \\
\text { cost savings }\end{array}$ & $\begin{array}{l}\text { - Interactions between } \\
\text { microbial communities } \\
\text { and QS affects system } \\
\text { performance } \\
\text { - } \text { Potential of Quorum } \\
\text { quenching (QQ) } \\
\text { bacteria for QS signal } \\
\text { degradation by } \\
\text { secretion of certain } \\
\text { enzymes }\end{array}$ \\
\hline Cometabolism & $\begin{array}{l}\text { The simultaneous metabolism of two or more } \\
\text { compounds, during which the degradation of the } \\
\text { main compound and the contaminant depends on } \\
\text { the presence of other compounds, which serve as } \\
\text { the source of energy to achieve high removal levels } \\
\text { for the biodegradable fraction by the addition of an } \\
\text { adequate energy source. Cometabolism may be } \\
\text { realized by virtue of multiple bacterial synergism. }\end{array}$ & $\begin{array}{l}\text { Acetate, glucose, sucrose, methanol, } \\
\text { molasses, etc. }\end{array}$ & $\begin{array}{l}\text { - Could increase enzymatic activity } \\
\text { and the elimination rate of non- } \\
\text { growth substrates. } \\
\text { - Efficient bioaugmentation way } \\
\text { used to remove many refractory } \\
\text { organics economically and } \\
\text { environmental-friendly such as } \\
\text { ethyl mercaptan }\end{array}$ & $\begin{array}{l}\text { The process is usually } \\
\text { not enough for the } \\
\text { slowly biodegradable } \\
\text { COD } \\
\text { - Extra energy } \\
\text { requirement }\end{array}$ \\
\hline Augmentation & $\begin{array}{l}\text { The addition of materials in a reactor to facilitate } \\
\text { the removal of undesired contaminants present. }\end{array}$ & $\begin{array}{l}\text { Heavy metals, nanoparticles, carbon } \\
\text { nanotubes, activated carbon, metabolic } \\
\text { uncouplers, adsorbents and coagulants }\end{array}$ & $\begin{array}{l}\text { - Formation and enhancement of } \\
\text { aerobic granules }\end{array}$ & $\begin{array}{l}\text { - Potential to increase } \\
\text { toxicity in SBR system }\end{array}$ \\
\hline Biougmentation & $\begin{array}{l}\text { It is the introduction of a specific strain of } \\
\text { microorganisms to accelerate and enhance the } \\
\text { removal efficiency of contaminants from polluted } \\
\text { sites and bioreactors. It is used to maximize nitrifier } \\
\text { population and improve microorganism resistance } \\
\text { to pH variations, toxic agents, changes in } \\
\text { temperature and shock loading. Its success or failure } \\
\text { depends on the ability of the introduced bacteria to } \\
\text { survive and to display their activities in the mixed } \\
\text { culture. It uses cultured halophilic organisms and } \\
\text { biofilm systems to improve the performance of } \\
\text { conventional activated sludge processes in } \\
\text { wastewater treatment. }\end{array}$ & $\begin{array}{l}\text { Archaea, (genus Pseudomonas and } \\
\text { Bacillus, Pseudomonas sp. HF-1, } \\
\text { Pseudomonas stutzeri TR2 and XL-2, } \\
\text { Micrococcus sp., Thiosphaera } \\
\text { Pantotropha, bacteria strain AD4 } \\
\text { (Delftia sp.), Pseudomonas mendocina } \\
\text { IHB602, Rhizobium sp. NJUST18, } \\
\text { Bacillus sp. K5, Comamonas } \\
\text { testosterone, Bacillus cereus, pNB2 } \\
\text { donor strain (Pseudomonas putida } \\
\text { SM1443 and ONBA-17), Burkholderia } \\
\text { epacian PCL3, alkali-tolerant strain } \\
\text { JY-2, acyl-CoA synthetase-4 (ACSL4) }\end{array}$ & $\begin{array}{l}\text { - Could support the start-up of new } \\
\text { reactors. } \\
\text { - } \text { Could promote reactor start-up } \\
\text { - Improves process stability, odor } \\
\text { reduction and biogas yield in an } \\
\text { anaerobic system. } \\
\text { - Cultivation of aerobic granule. } \\
\text { - Rapid reduction of toxicity to the } \\
\text { microbial community. }\end{array}$ & $\begin{array}{l}\text { - It is not yet a common } \\
\text { technique, since its } \\
\text { results are hard to } \\
\text { predict and monitor } \\
\text { - Inability to retain the } \\
\text { specialized } \\
\text { bacteria }\end{array}$ \\
\hline
\end{tabular}




\begin{tabular}{|c|c|c|c|c|}
\hline Granulation & $\begin{array}{l}\text { A form of microbial aggregation in wastewater } \\
\text { treatment systems. It can be formed in SBR by an } \\
\text { anaerobic sludge, aerobic heterotrophs, acidifying, } \\
\text { nitrifying and denitrifying bacteria. Aerobic } \\
\text { granulation is a process where the suspended } \\
\text { aggregate of biomass forms discrete well-defined } \\
\text { granules in aerobic systems. They could be utilized } \\
\text { to remove organic matter, nitrogen, phosphorus, and } \\
\text { decomposition of toxic wastewaters simultaneously. }\end{array}$ & $\begin{array}{l}\text { 2,4,6-trichlorophenol }(2,4,6-\mathrm{TCP}), \\
\text { Rhizobium sp. NJUST18, hexavalent } \\
\text { chromium Cr(VI), autotrophic } \\
\text { ammonium-oxidizing bacteria, } \\
\text { activated carbon, zero-valent iron and } \\
\text { divalent metal ions, such as } \mathrm{Ca}^{2+}, \mathrm{Fe}^{2+} \text {, } \\
\mathrm{Mg}^{2+} \text {, biofilm formation and carbon } \\
\text { source materials }\end{array}$ & $\begin{array}{l}\text { - Leads to excellent settling, high } \\
\text { biomass retention, higher organic } \\
\text { loading rates, more compact } \\
\text { structure, tolerance of shock } \\
\text { loading, reduced investment cost, } \\
\text { resistance to inhibitory and toxic } \\
\text { compounds and multiple } \\
\text { biological functions }\end{array}$ & $\begin{array}{l}\text { - Formation mechanism } \\
\text { for cultivating aerobic } \\
\text { granules are uncertain } \\
\text { - Complicated process of } \\
\text { aerobic granulation } \\
\text { - Long-term operation of } \\
\text { AGS reactors often } \\
\text { results in granular } \\
\text { instability or even } \\
\text { disintegration }\end{array}$ \\
\hline
\end{tabular}

Table 10. Materials for SBR enhancement

\begin{tabular}{|c|c|c|c|c|c|c|c|c|}
\hline Biofilm materials & Membranes & Biofilters & $\begin{array}{l}\text { Metabolic } \\
\text { uncouplers }\end{array}$ & Nanoparticles & $\begin{array}{l}\text { Carbon } \\
\text { nanotubes }\end{array}$ & $\begin{array}{l}\text { Heavy } \\
\text { metals }\end{array}$ & Carbon source & Adsorbents \\
\hline $\begin{array}{l}\text { Fiber: Fibrous packing media, fiber } \\
\text { threads, spiral fiber, polyester fiber, } \\
\text { rayon fiber, carbon fiber threads, } \\
\text { Imitation-aquatic-grass spiral fibers, } \\
\text { polyvinyl formal } \\
\text { fiber, synthetic fiber, polymeric fibrous } \\
\text { carriers obtained from polyamide, } \\
\text { polypropylene, and polyethylene }\end{array}$ & $\begin{array}{l}\text { Membrane } \\
\text { diffuser }\end{array}$ & $\begin{array}{l}\text { Filter } \\
\text { wool }\end{array}$ & $\begin{array}{l}\text { DNP }(2,4- \\
\text { dinitrophe } \\
\text { nol) }\end{array}$ & $\begin{array}{l}\text { Silver } \\
\text { nanoparticle } \\
\text { (AgNP) }\end{array}$ & $\begin{array}{l}\text { Amino- } \\
\text { functionalize } \\
\mathrm{d} \text { multi- } \\
\text { walled } \\
\text { carbon } \\
\text { nanotubes } \\
\left(\mathrm{MWCNTS-}^{\mathrm{N}}\right. \\
\left.\mathrm{NH}_{2}\right)\end{array}$ & $\mathrm{Hg}^{2+}$ & $\begin{array}{l}\text { Sodium bicarbonate, sodium } \\
\text { propionate, Sodium succinate, } \\
\text { Sodium acetate (NaAc), poly- } \\
\text { 3-hydroxybutyrate, } \\
\text { polyhydroxyalkanoates } \\
\text { (PHAs), polyphosphate, } \\
\text { potassium bicarbonate, Lactate }\end{array}$ & $\begin{array}{l}\text { Powdered } \\
\text { cockleshell (PCS), } \\
\text { Powdered ZELIAC } \\
\text { (PZ), Powdered } \\
\text { BAZLASC, } \\
\text { Powdered } \\
\text { keramsite }\end{array}$ \\
\hline $\begin{array}{l}\text { Sponge: Luffa, biocube, polyurethane } \\
\text { cubic, and polypropylene plastic } \\
\text { sponge media }\end{array}$ & $\begin{array}{l}\text { Hollow fibre } \\
\text { micro- } \\
\text { filtration } \\
\text { (MF) } \\
\text { membrane } \\
\text { module }\end{array}$ & $\begin{array}{l}\text { Rotating } \\
\text { belt filter }\end{array}$ & $\begin{array}{l}\text { TCS } \\
(3,3,4,5- \\
\text { tetrachloro } \\
\text { salicylanili } \\
\text { de) }\end{array}$ & $\begin{array}{l}\text { Zinc oxide } \\
\text { nanoparticles } \\
\text { (ZnO NPs) }\end{array}$ & $\begin{array}{l}\text { Single- } \\
\text { walled } \\
\text { CNTs } \\
\text { (SWCNTs) }\end{array}$ & $\mathrm{Cd}^{2+}$ & $\begin{array}{l}\text { Ethanol, Mannitol, Glycerol, } \\
\text { Cresol, 4-chlorophenol, } \\
\text { Phenol, Methanol, butanol, } \\
\text { ethylene glycol, Monoethylene } \\
\text { glycol (MEG) }\end{array}$ & Tourmaline \\
\hline $\begin{array}{l}\text { Fillers: elastic fillers, fibrous filler, } \\
\text { semi-soft fiber filler, polyolefin resin } \\
\text { filler, activated carbon filler }\end{array}$ & $\begin{array}{l}\text { Hydrophobi } \\
\text { cpoly } \\
\text { propylene } \\
\text { dense } \\
\text { hollow } \\
\text { fibers in } \\
\text { cylindrical } \\
\text { plastic shell }\end{array}$ & $\begin{array}{l}\text { flat-sheet } \\
\text { type } \\
\text { module }\end{array}$ & $\begin{array}{l}\text { pNP (para- } \\
\text { dinitrophe } \\
\text { nol) }\end{array}$ & $\begin{array}{l}\text { Cerium } \\
\text { dioxide } \\
(\text { nanoCeO }\end{array}$ & $\begin{array}{l}\text { Carboxylated } \\
\text { multiwall } \\
\text { carbon } \\
\text { nanotubes } \\
\text { (CNT- } \\
\text { COOH) }\end{array}$ & $\mathrm{Cu}^{2+}$ & $\begin{array}{l}\text { Acetic, butyric, citric, humic, } \\
\text { oleic, phthalic, propionic, and } \\
\text { volatile fatty acids }\end{array}$ & $\begin{array}{l}\text { Chlorine dioxide } \\
\left(\mathrm{ClO}_{2}\right)\end{array}$ \\
\hline $\begin{array}{l}\text { Balls: porous polyacrylonitrile } \\
\text { Balls, fiber balls, BioBall }\end{array}$ & $\begin{array}{l}\text { flat- } \\
\text { polyamide } \\
\text { membrane }\end{array}$ & $\begin{array}{l}\text { Mesh } \\
\text { Sieve }\end{array}$ & $\begin{array}{l}\text { DCP }(2,4- \\
\text { dichloroph } \\
\text { enol) }\end{array}$ & $\begin{array}{l}\text { Cupric oxide } \\
\text { (CuO NPs) }\end{array}$ & $\begin{array}{l}\text { Carboxylated } \\
\text { multiwall } \\
\text { carbon } \\
\text { nanotubes } \\
\text { (CNT- } \\
\text { COOH) }\end{array}$ & $\mathrm{Pb}^{2+}$ & $\begin{array}{l}\text { Glucose, Dextrose, Xylose, } \\
\text { Sucrose }\end{array}$ & $\begin{array}{l}\text { Calcium phosphate } \\
\mathrm{Ca}_{5}\left(\mathrm{PO}_{4}\right)_{3}(\mathrm{OH})\end{array}$ \\
\hline $\begin{array}{l}\text { Activated carbon materials: rice } \\
\text { husks, chitosan, coconut shell-based }\end{array}$ & $\begin{array}{l}\text { Polyvinylide } \\
\text { ne difluoride } \\
\text { (PVDF) }\end{array}$ & $\begin{array}{l}\text { Plastic } \\
\text { media }\end{array}$ & $\begin{array}{l}\text { TCP } \\
(2,4,6-\end{array}$ & $\begin{array}{l}\text { Magnesium } \\
\text { oxide }\end{array}$ & $\begin{array}{l}\text { Pristine } \\
\text { multi-walled }\end{array}$ & $\mathrm{Ni}^{2+}$ & $\begin{array}{l}\text { Nitrobenzene, Nicotine, } \\
\text { Aniline, Peptone, } n \text {-alkane, }\end{array}$ & $\begin{array}{l}\text { Polyaluminum } \\
\text { chloride (PACl) }\end{array}$ \\
\hline
\end{tabular}




\begin{tabular}{|c|c|c|c|c|c|c|c|c|}
\hline $\begin{array}{l}\text { GAC, polyacrylonitrile-based activated } \\
\text { carbon fibres }\end{array}$ & & & $\begin{array}{l}\text { trichloroph } \\
\text { enol) }\end{array}$ & $\begin{array}{l}\text { nanoparticles } \\
\text { (MgO NPs) }\end{array}$ & $\begin{array}{l}\text { CNTs } \\
\text { (MWCNTs) }\end{array}$ & & & \\
\hline $\begin{array}{l}\text { Stones: volcanic pumice stones Inert } \\
\text { stone chips }\end{array}$ & $\begin{array}{l}\text { Polysulfone } \\
\text { (PSF) } \\
\text { ultrafiltratio } \\
\mathrm{n} \quad \text { (UF) } \\
\text { supports } \\
\end{array}$ & $\begin{array}{l}\text { Ceramsit } \\
\text { e filter } \\
\text { media }\end{array}$ & $\begin{array}{l}2,6- \\
\text { dichloroph } \\
\text { enol }(2,6- \\
\text { DCP })\end{array}$ & $\begin{array}{l}\text { Surfactant- } \\
\text { coated iron } \\
\text { oxide } \\
\text { nanoparticles } \\
\text { (FeO NPs) }\end{array}$ & & $\mathrm{Ca}^{2+}$ & $\begin{array}{l}\text { Vegetable oils, fusel oil, } \\
\text { soybean oil }\end{array}$ & $\begin{array}{l}\text { Ethylenediamine- } \\
\text { modified rice husk } \\
(\mathrm{MRH})\end{array}$ \\
\hline $\begin{array}{l}\text { Disk: acid-proof steel disk, stainless } \\
\text { steel disk, polyacrylonitrile disk }\end{array}$ & $\begin{array}{l}\text { Submerged } \\
\text { flat sheet } \\
\text { membrane } \\
\text { module }\end{array}$ & $\begin{array}{l}\text { cartridge } \\
\text { filter }\end{array}$ & $\begin{array}{l}\text { 2,4- } \\
\text { Dichlorop } \\
\text { henoxyace } \\
\text { tic acid } \\
(2,4-\mathrm{D})\end{array}$ & $\begin{array}{l}\text { Nickel oxide } \\
\text { nanoparticles } \\
(\mathrm{NiO} \text { NPs) }\end{array}$ & & $\mathrm{Mg}^{2+}$ & $\begin{array}{l}\text { Waste beer, food waste, starch, } \\
\text { brown sugars, Emsize E1, } \\
\text { Tween } 80\end{array}$ & $\begin{array}{l}\text { Acetogenic bacteria } \\
\text { BP103 cells }\end{array}$ \\
\hline $\begin{array}{l}\text { Beads: polyethylene beads, clay beads, } \\
\text { glass beads, alginate-light-expanded } \\
\text { clay aggregates (LECA) beads }\end{array}$ & $\begin{array}{l}\text { polyphenol } \\
\text { resin plate } \\
\text { and frame } \\
\text { modules }\end{array}$ & $\begin{array}{l}\text { wood } \\
\text { chip } \\
\text { filters }\end{array}$ & $\begin{array}{l}1,1,1- \\
\text { Trichloroet } \\
\text { hane } \\
\text { (TCA) }\end{array}$ & $\begin{array}{l}\text { MgAl-layered } \\
\text { double } \\
\text { hydroxide } \\
\text { (MgAl-LDH) } \\
\text { nanoparticles }\end{array}$ & & $\mathrm{Zn}^{2+}$ & $\begin{array}{l}\text { Yeast extract, bonito extract, } \\
\text { beef extract, meat extract }\end{array}$ & $\begin{array}{l}\text { Sodium chloride } \\
(\mathrm{NaCl})\end{array}$ \\
\hline $\begin{array}{l}\text { Rings: Inert porcelain rings, Pall rings, } \\
\text { ring lace, polyethylene (PE) rings }\end{array}$ & $\begin{array}{l}\text { polyethersul } \\
\text { fone (PES) } \\
\text { microfiltrati } \\
\text { on } \\
\text { membrane }\end{array}$ & & $\begin{array}{l}2,4,6- \\
\text { Trinitroph } \\
\text { enol } \\
\text { (Picric } \\
\text { Acid) }\end{array}$ & $\begin{array}{l}\text { Magnetic } \\
\mathrm{Fe}_{3} \mathrm{O}_{4} \\
\text { nanoparticles }\end{array}$ & & $\mathrm{Cr}(\mathrm{VI})$ & tert-Butyl Alcohol (TBA) & $\begin{array}{l}\text { Metal hydroxide } \\
\text { waste sludge (WS) }\end{array}$ \\
\hline $\begin{array}{l}\text { Polyurethane: Polyurethane foam } \\
\text { loaded tourmaline (TPU) carrier, } \\
\text { polyurethane spheres, Polyurethane } \\
\text { foam cube }\end{array}$ & $\begin{array}{l}\text { polyacryloni } \\
\text { trile (PAN) } \\
\text { microfiltrati } \\
\text { on } \\
\text { membrane } \\
\end{array}$ & & $\begin{array}{l}\text { Malonic } \\
\text { Acid (MA) }\end{array}$ & $\begin{array}{l}\text { Selenium } \\
\text { nanoparticles } \\
\text { (SeNPs) }\end{array}$ & & & Lysogeny broth (LB) & Chabazite \\
\hline $\begin{array}{l}\text { Polypropylene: Bioflow30 from } \\
\text { recycled polypropylene, polypropylene } \\
\text { hoop }\end{array}$ & $\begin{array}{l}\text { Zenon ZW- } \\
10 \text { hollow- } \\
\text { fibre ultra- } \\
\text { filtration } \\
\text { (UF) } \\
\text { membrane }\end{array}$ & & $\begin{array}{l}\text { 2,4- } \\
\text { dinitroanis } \\
\text { ole } \\
\text { (DNAN) }\end{array}$ & $\begin{array}{l}\text { Silica } \\
\text { nanoparticles } \\
\left(\mathrm{SiO}_{2} \mathrm{NPs}\right)\end{array}$ & & & Biochar & Ceramsite \\
\hline $\begin{array}{l}\text { Polyethylene: DupUM, Biolox10 from } \\
\text { recycled polyethylene, Bee Cell } 2000 \\
\text { media made of High Density Poly } \\
\text { Ethylene (HDPE), Naps of } \\
\text { polyethylenstyrol (PES) textile material }\end{array}$ & $\begin{array}{l}\text { Polypropyle } \\
\text { ne frame and } \\
\text { sponge }\end{array}$ & & $\begin{array}{l}\text { 3-nitro- } \\
1,2,4- \\
\text { triazol-5- } \\
\text { one }\end{array}$ & $\begin{array}{l}\text { Aluminum } \\
\text { oxide } \\
\text { nanoparticles } \\
\left(\mathrm{Al}_{2} \mathrm{O}_{3} \mathrm{NPs}\right)\end{array}$ & & & Milk powder & $\begin{array}{l}\text { Pyrolysed rice husk } \\
\text { (PRH) }\end{array}$ \\
\hline $\begin{array}{l}\text { WD- } \mathrm{F}_{10-4} \text { BioM }^{\mathrm{TM}} \text { composite of } \\
\text { polyethylene and inorganics, } \\
\text { polyethylene biocarriers }\end{array}$ & $\begin{array}{l}\text { ZeeWeed } \\
\text { ZW10 }\end{array}$ & & & $\begin{array}{l}\text { Titanium } \\
\text { dioxide } \\
\left(\text { nanoTiO }_{2}\right) \\
\end{array}$ & & & $\begin{array}{l}\text { Waste activated sludge } \\
\text { alkaline fermentation liquid }\end{array}$ & $\begin{array}{l}\text { Powdered and } \\
\text { Granular activated } \\
\text { carbon }\end{array}$ \\
\hline $\begin{array}{l}\text { Acrylonitrile-butadiene-styrene (ABS), } \\
\text { cell-immobilized polyethylene glycol } \\
\text { (PEG) pellets, }\end{array}$ & & & & $\begin{array}{l}\text { Zero-valent } \\
\text { iron (NZVI) }\end{array}$ & & & $\begin{array}{l}\text { Acid-fermented primary and } \\
\text { secondary sludge centrate }\end{array}$ & Corncob \\
\hline
\end{tabular}




\begin{tabular}{|c|c|c|c|}
\hline $\begin{array}{l}\text { Non-woven porous polyester, porous } \\
\text { polymers, polycaprolactone spheres, } \\
\text { polyphenol resin microfiltration plate, } \\
\text { PVC modules, automobile tires }\end{array}$ & Fullerene & $\begin{array}{l}\text { Non-digested pig manure, } \\
\text { fecula, molasses and } \\
\text { chloroanilines }\end{array}$ & Zeolite, \\
\hline $\begin{array}{l}\text { Centrifuge tubes, nylon nets, peach pit, } \\
\text { iron shavings, filamentous supporting } \\
\text { rope-type media, coir geotextiles }\end{array}$ & $\begin{array}{l}\text { Graphene } \\
\text { oxide (GO) }\end{array}$ & $\begin{array}{l}\text { Fermentation slurry, Landfill } \\
\text { leachate }\end{array}$ & $\begin{array}{l}\text { Pinewood (Pinus } \\
\text { sp.) chip, Agave } \\
\text { tequilana bagasse }\end{array}$ \\
\hline $\begin{array}{l}\text { Mineral coal, charcoal, eucalyptus } \\
\text { charcoal, rock wool, lava rock, } \\
\text { ceramics, palm oil clinker media } \\
\text { (POCM), blasted clay granules }\end{array}$ & & $\begin{array}{l}\text { Spent mushroom compost } \\
(\mathrm{SMC}) \text { hydrolysates }\end{array}$ & Foam glass bead \\
\hline
\end{tabular}




\subsection{Effect of Hybrid SBR configurations on leachate treatment}

Hybrid SBR is an innovative novel configured system enhanced over the conventional SBR. It exists when an SBR is coupled or modified with either a moving or fix support material thereby combining the advantages of the SBR and the modified or coupled material. Some notable generic advantages are: ability to grow different types of bacteria, greater biomass retention, volumetric efficiency, better resistance to inhibitory effects, low footprint, cost reduction (da Costa, Souto, Prelhaz, Neto, \& Wolff, 2008), low energy requirements, stability and resistance to shock loads. The specific advantages for various hybrid configurations have been highlighted in Table 11. Furthermore, the performance of a hybrid SBR depends on the nature of modification carried out as different modification materials, methods and conditions offer variable properties to the system.

In a biofilm modified SBR where biomass carriers with non-uniform structure, high rate of specific surface area, lower density than wastewater, intermittent flux and variable amounts of oxygen within layers, there is simultaneous occurrence of suspended and attached growth of microorganisms in a single bioreactor combining the advantages of the activated sludge, biofilm system and SBR (da Costa et al., 2008). Study revealed that biofilm and suspended sludge interaction by lab-scale aerobic hybrid system resulted in a better overall nitrogen removal performance via SND (She et al., 2018).

A Sequencing Batch Rotating Disk Reactor (SBRDR) was used to develop a stable partial nitrification to nitrite based on automatic interruption of aeration at the endpoint of ammonia oxidation and a supervisory $\mathrm{pH}$ control. The formation of a thin nitrifying biofilm enriched with ammonia oxidizing bacteria promoted the nitrification process. Study concluded that batch operation of the SBRDR can lead to a low aeration cost and high nitrite build-up, with simultaneous total ammonium removal (Antileo et al., 2006).

According to study by (Cramer, Tranckner, \& Kotzbauer), the design of a trickling filter operating in a SBR mode (SBR-TF) for nutrient removal, must cater for the aerobic, anoxic and anaerobic conditions. During operation, system has to be ponded with a mixture of filtered wastewater from the secondary sedimentation tank and untreated raw water to pave the way for upstream denitrification and EBPR integration. Finding revealed that pairing trickling filter with activated sludge system in one single reactor is feasible as it enabled nutrient removal without an additional ASS, save aeration energy, costs and space.

A lab-scale sequencing batch reactor (SBR) was retrofitted to a green bio-sorption reactor (GBR) by embedding constructed wetland $(\mathrm{CW})$ into the aeration tank of the conventional activated sludge (CAS) to demonstrate its performance. The reactor as depicted in Fig. 5 is said to have high purification efficiency, aesthetic value and potential carbon sink. Thus, making it sustainable and economical (R. B. Liu, Zhao, Zhao, Xu, \& Sibille, 2017).

The coupling of SBR (biodegradation) and an electrochemical system into one entity (Bio-electrochemical system) under aerobic conditions significantly improved the treatment efficiency for saline wastewater by alleviating the impact of salinity stress on the bacterial community. The system greatly improve bioactivity and microbial metabolism (J. X. Liu et al., 2017). In a related study, where electrical current was passed through a sequencing batch reactor with biofilm immobilized on a carrier in the form of disks (SBBR) enabled chemical treatment. Nitrogen and phosphorus compounds were removed in the process of autotrophic denitrification and coagulation respectively. Electrical current passage contributed to a significant increase in the denitrification efficiency (Klodowska, Rodziewicz, \& Janczukowicz, 2018).

\subsubsection{Algae-based sequencing batch suspended biofilm reactor (A-SBSBR)}

This is a system where biofilm material can rise to surface at non-aeration period to get more illumination and optical energy for algae growth and enrichment. The biofilm material can obtain sufficient substance exchange between wastewater, sludge and algae at aeration period. Under illumination, algae capture dissolved or released $\mathrm{CO}_{2}$ to produce oxygen through photosynthesis expected to be utilized by bacteria for pollutant degradation (Tang, Tian, He, Zuo, \& Zhang, 2018).

\subsubsection{An airlift loop sequencing batch biofilm reactor}

An airlift loop SBBR depicted in Fig. 6, classified as a fixed reactor, divided into aeration and reverse flow zones and designed to combine nitrification and denitrifying phosphorus removal operated through the influent, anaerobic, aerobic/anoxic and effluent phases. Carrier packing in the two zones enhanced the predominant growth of DNPAOs in the aeration and reverse flow zones respectively. Sludge decant was the major factor affecting the efficiency of phosphorous removal which could be regulated by switching carriers packing density (Z. Y. Zhang, Zhou, Wang, Guo, \& Tong, 2006). 


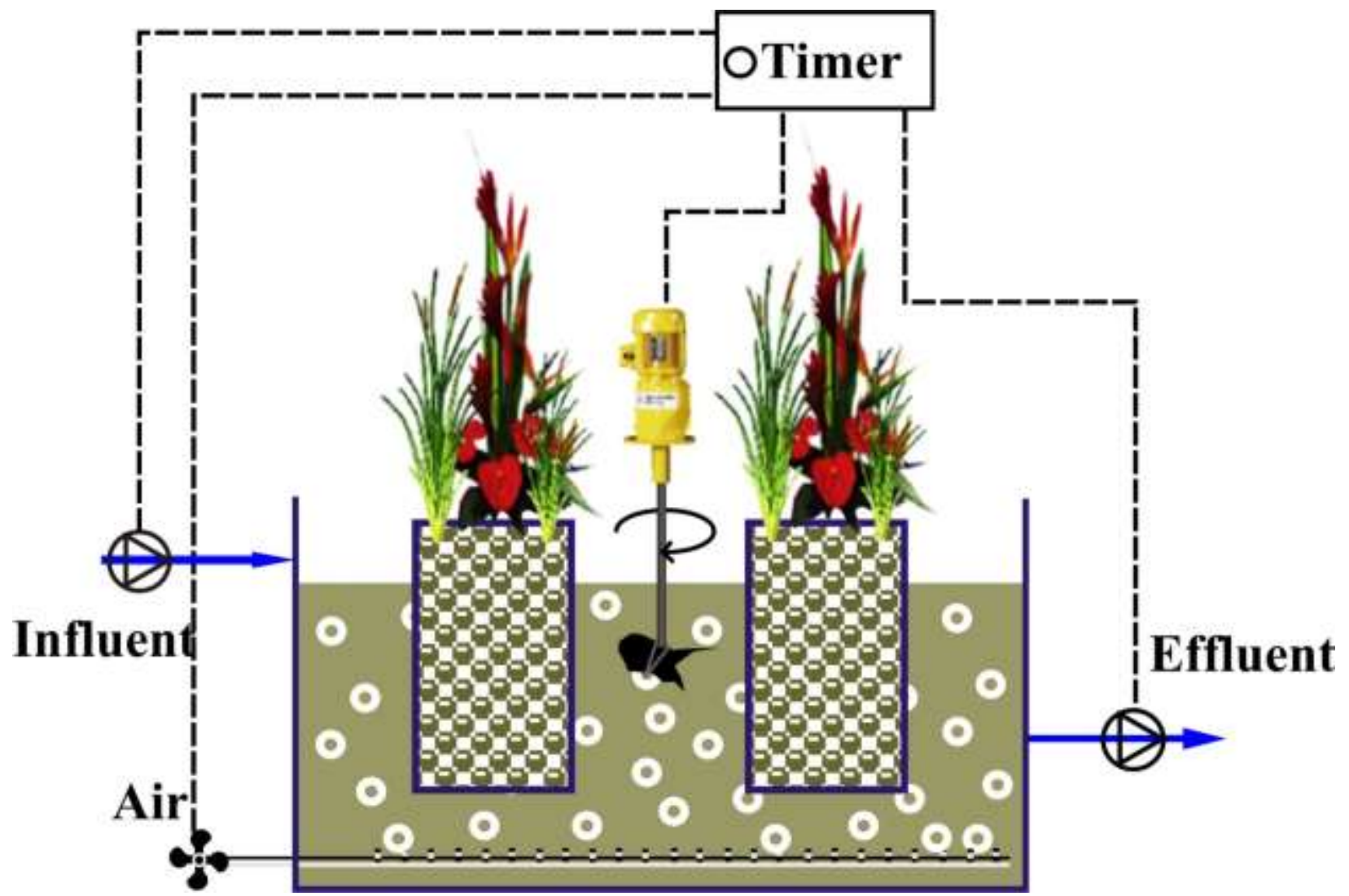

Fig. 5. Schematic diagram of constructed wetland based green biosorption SBR (GB-SBR) (R. B. Liu et al., 2017).

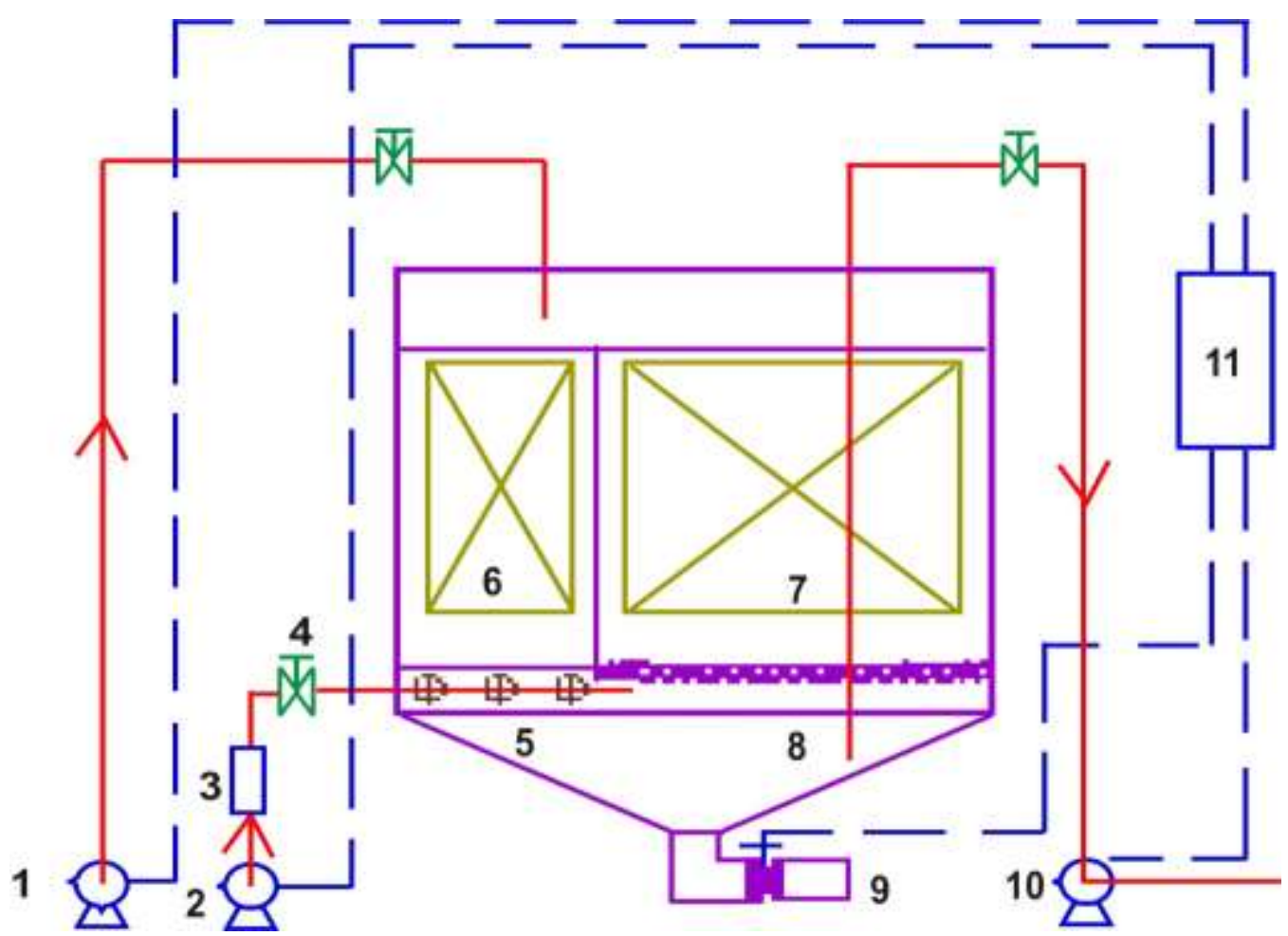

(1) Influent pump (2) air pump (3) rotameter (4) valve (5) air diffuser (6) aeration zone (7) reverse flow zone (8) rotatable baffles (9) sludge discharge pipe (10) effluent pump (11) automatic control device

Fig. 6. Schematic diagram of an airlift loop sequencing batch biofilm reactor (Z. Y. Zhang et al., 2006). 


\subsubsection{Pressurized sequencing batch reactor}

Pressurized aeration is a method used to improve oxygen transfer momentum. The pressurized activated sludge process enhances the solubility of oxygen by increasing total air pressure, with a result of promoted oxygen transfer rate. Activated sludge and biofilm with pressurized aeration technology are said to be more effective than those in traditional aeration systems. Degradation rate of organic matters could be dramatically increased when activated sludge process is running under high organic load by effectively reducing aeration tank volume and hydraulic detention time through the application of pressurized aeration. Pressurized unit could obtain a substantial saving, especially when the treatment process is for larger populations. There is a general tendency of microbial growth inhibition under high pressure of several hundred bars. These pressures could inactivate and eliminate microorganisms, and consequently provide a longer storage time for various materials and food. However, the effects of high pressure are not of relevance to industrial aerobic bioreactors, where the moderate pressure is often controlled to less than 1.0 MPa. Moderate pressures have been demonstrated to cause no damage to several culture processes (Y. Zhang et al., 2017). Results in a study by (Elkaramany, Elbaz, Mohamed, \& Sakr, 2018) revealed that the use of recycled pressurized air in the pressurized SBR increased the contact time between air bubbles and wastewater threefold compared with the conventional SBR model and increased the rate of DO in wastewater.

\subsubsection{Micro-electrolysis in Sequencing Batch Reactor}

Micro-electrolysis technology, otherwise referred to as iron reduction process, iron-carbon method or internal electrolysis process is based on the theory of corrosion electrochemistry of metal. It is the integration of electroaggregation and electro-coagulation that utilizes electrode reaction of micro-battery formed in electrolyte solution for wastewater treatment with inert carbon particles and iron scrap as reactor fillers (Ying, $\mathrm{Xu}$, et al., 2012). It is a promising method for treating mature landfill leachate proven to be efficient in humic acids, color and metal ions degradation with $\mathrm{BOD}_{5} / \mathrm{COD}$ ratio. SBR based on internal micro-electrolysis (IME) reaction is capable of integrating reductive and oxidative IME in a unit reactor. The process could also be applied through reconstruction of existing technology by adding a group of iron-carbon SBR reactor and suitable for the medium and small projects. This system configuration require regular cleaning in acidic condition leading to excessive consumption of Fe and is faced with Limited treatment capacity (T. Duan et al., 2012).

\subsubsection{Granular sequencing batch reactor}

Aerobic granular sludge is the biomass aggregates grown under aerobic conditions without a carrier material (He, Zhang, Zou, Zheng, \& Wang, 2016). Aerobic granular sludge possesses regular and dense physical structure, regular morphology, impact microbial structure, and great ability to withstand shock load and toxic compounds. It has severally been reported that Aerobic granules might disintegrate after prolonged operation due to overloading, hydrolysis of the anaerobic core, unbalanced substrates, inappropriate operational configurations, loss of functional strains, intrusion of stressing compounds, outgrowth of filamentous organisms, and secretion of EPS. However, strategies such as the selection of a slow-growing organism, suppressing activity of anaerobes, application of appropriate operational conditions and strengthening granule were identified for developing more stable granules. Nitrification, denitrification and TN removal rate could be influenced by anoxic and aerobic volumes built-up by DO penetration in the single granules. Biomass spatial distribution, activity of diverse bacteria species and granule size and density are responsible for DO diffusion in granules (F. Y. Chen et al., 2011). On the contrary, high salinity and low temperature negatively affects aerobic granular sludge performance and stability (He et al., 2020).

\subsubsection{Fixed bed sequencing batch reactor (FBSBR)}

Fixed bed biofilm SBR reactors can be operated at significantly higher organic loading rates (OLR) (Rahimi, Torabian, Mehrdadi, \& Shahmoradi, 2011). The biofilm systems with supported biomass are responsible for overcoming possible high hydraulic loading fluctuations. It determines the maintenance of microorganism capacity and the slow growth of microorganisms in the reactor (Soltani, Rezaee, Godini, Khataee, \& Jorfi, 2013). More so, oxygen gradient in biofilm layer can pave way for higher total phosphorus (TP) removal in the system. Difficulties associated with the operation of fixed bed biofilm systems are clogging, necessity of backwash, High nutrient content and stabilization ratio (Koupaie, Moghaddam, \& Hashemi, 2011).

\subsubsection{Moving bed sequencing batch reactor (MBSBR)}

The moving-bed sequencing batch reactor (MBSBR) is an attached growth process developed on the basis of conventional activated sludge process and biofilter process for wastewater remediation. The activated sludge and 
biomass are intermixed and grown on the surfaces of small moving biofilm support media that have slightly lighter density than water and are circulated by a water stream inside the reactor (Koupaie et al., 2011). Support media selection for MBSBR is highly consequential in maximizing nitrogen removal due to limitations as media clogging, head loss, and hydraulic instability (Tan et al., 2016). In a narration by (Malakootian, Shahamat, \& Mahdizadeh, 2020), suspended biomass presents higher specific degradation rates and SND efficiency depends on DO, biofilm thickness, availability of carbon source and influent concentration. Thicker biofilm is beneficial for SND. This system is highly recommended for the treatment of non-biodegradable industrial wastewater.

\subsubsection{Integrated fixed-film activated sludge sequencing batch reactor (IFAS-SBR)}

Integrated fixed-film activated sludge (IFAS-SBR) is the integration of biocarriers into conventional activated sludge reactors to provide surface area for the bacterial attachment and growth. The combined materials are the basic bacterial aggregates that promote nitrification. Investigating microbial community structure is the key to understand their individual functions. The system is extensively used in treating low strength wastewater. Biosorption and biodegradation are the major mechanisms for pollutant removal in the IFAS-SBR system. Thus, creating favorable conditions for denitrifiers and modifying reaction and settling time are said to promote nitrate removal (Shao et al., 2018). Compared to fixed media, mobile media facilitates high oxygen and nutrient transfer in reactors. It has been proven that biofilm is more favorable habitat for nitrifiers as extracellular polymeric substance (EPS) in biofilm and suspended flocs changes in response to the organic loading variability.

\subsubsection{Membrane coupled sequencing batch reactor}

Membrane coupled sequencing batch reactor as depicted in Fig. 7 is a technology with the potential of providing engineering flexibility in organic, nutrients and toxic compounds removal from wastewater (S. N. Xu et al., 2014). It is excellent in replacing the sedimentation and decanting phases of an SBR process with increased sludge particle size range, apparent viscosity and soluble microbial products concentration. It also serves as an advanced treatment unit (Frank et al., 2017) for coliform bacteria. However, membrane bioreactors processes are constrained by their tendency to foul. Thus, subsequently requiring membrane cleaning. Reported possible causes of fouling are: operating conditions, membrane characteristics, MLSS concentration, microbial products present, feed and concentration, F/M ratio, floc characteristics (Fakhru'l-Razi et al., 2010). Fouling can be reduced by either maintaining turbulent conditions or operating at sub-critical flux (Arrojo et al., 2005). It can also be mitigated by providing a feast famine environment during SBR operation that favors biogranulation of activated sludge. Air backwashing can temporarily keep membrane clean, after which mechanical cleaning of the fouled membrane became necessary (Shariati et al., 2011). 

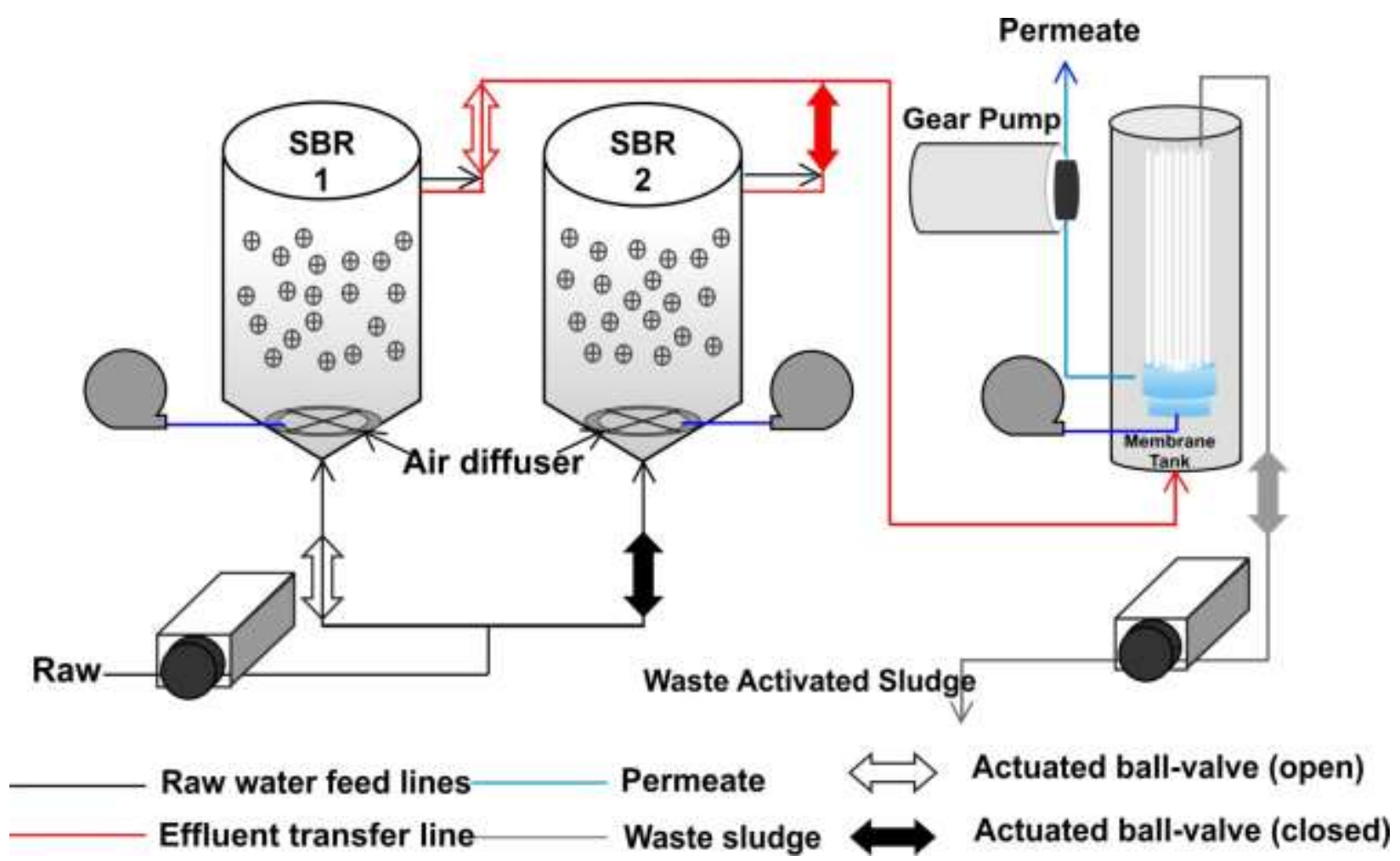

Fig. 7. Process flow diagram for the sequencing batch reactor-membrane bioreactor (SBR-MBR) (Frank et al., 2017)

\subsubsection{Ultrasound-induced sequencing batch reactor}

Ultrasonic process considered as a new technology for high rate biological wastewater treatment processes is defined as acoustic or sound waves with frequencies above natural human hearing limit ( $>20 \mathrm{kHz})$. Interestingly, ultrasonic parameters (e.g. irradiation cycle, frequency, intensity, proportion and time) are vital (Jin et al., 2013). Ultrasound application in SBR is a huge adventure for successful and cost-effective biological treatment. It is able to eradicate contaminants by generating radicals in the cavitation bubble. The impact of ultrasound waves on liquid causes the periodical compression and rarefaction of the medium (Neczaj et al., 2005). Ultrasonic wave frequency has a clear effect on the diameter of the produced bubbles. High frequency ultrasound generating smaller and more stable bubbles under high concentration of biomass and remarkably increasing effect on sludge settling velocity without adverse consequence on microbial activity made biological system more stable. Low ultrasonic frequency $(20-100 \mathrm{kHz})$ produces stronger hydrodynamic shear forces. Thus, sludge destabilization occurs at this level. Ultrasound irradiation at low intensity can be used in biological materials because it can improve the activity of enzymes, increase the transport of oxygen and nutrients to the cells, improve the permeability of cell membrane, promote cell growth and biosynthesis, and waste products transfer away from the cells, thus improving microbial cells operation and development (Zinadini, Rahimi, Zinatizadeh, \& Mehrabadi, 2015). For excess sludge reduction, several researchers employed $(<100 \mathrm{~Hz})$ and $\left(<2 \mathrm{~W} / \mathrm{cm}^{2}\right)$ as low frequency and intensity respectively. It was discovered that, sludge floc agglomerates were spread without cell destruction at short ultrasound application time. However, the microbial cell wall was weakened and intracellular materials released to the liquid phase at longer treatment time or higher ultrasound intensities (R. N. Zhang, Jin, Liu, Zhou, \& Li, 2011). In the case of raw landfill leachate, ultrasonic pretreatment boosts subsequent aerobic digestion, amounting to better degradation while sonification leads to enhancement of ammonia and COD removal at all influent leachate percentage addition as reported by (Grosser et al., 2019). This may be attributed to the fact that the medium 's periodic compression and rarefaction are caused by an ultrasonic wave in liquid.

\subsubsection{Photo-sequencing batch reactors (PSBRs)}

The PSBR is a compact and enclosed system where uniformly distributed low or high light is directly transmitted into the bioreactor to enhance pollutant degradation. Here, HRT and SRT are uncoupled to influence nutritional dynamics 
and biomass composition, thereby avoiding intensive harvesting process. To increase spontaneous flocculation and subsequent formation of large flocs in a PSBR, sedimentation period is added in the operational phases similar to most configured hybrid SBRs (M. Wang, Yang, Ergas, \& van der Steen, 2015). In PSBR, Light irradiation comprising of light intensity (LI), photoperiod and light quality had remarkable impacts on nutrients removal and algae growth, bioactivity and lipid production in an algae culture system. LI is essential for algal biomass growth and photosynthesis. It influences the production of oxygen, organic matter and good settling biomass. LI together with low DO concentration and high nitrite and ammonia concentrations can consequentially inhibit NOB significantly. Excess LI can induce the photoinhibition on algae, finally leading to an impaired biomass production and effluent water quality. Varying LI in a PSBR system during operation affects the biological communities in granules, thereby giving rise to different functional algae and bacteria (Meng et al., 2019). DO concentration highly affects nitrogen metabolism in the reactor system (Jia \& Yuan, 2018). PSBR are mostly used for development of algae-bacteria granular consortia. Natural sunlight induces rapid formation of water-born algal-bacterial granules in an aerobic bacterial granular PSBR. Findings by (He et al., 2018) revealed that the growth of water-born algae slightly decreased sludge settleability and the granules mean sizes but stimulated the bioactivity significantly. Photosynthetic oxygen production stimulates AOB during the light period. During the dark period, DO is quickly consumed by microbial activity and algal respiration, thus, promoting denitritation. Study by (Arun et al., 2019) proved alternating light and dark periods aid the complete BNR without external aeration.

\subsubsection{Photo-fermentative sequencing batch reactor (PFSBR)}

Photo-fermentative sequencing batch reactor (PFSBR) is a promising process for continuous photo-fermentative hydrogen production. However, low rate and yield of hydrogen production are main obstacles for commercialized photo-fermentative hydrogen production. This could be attributed to the low biomass retention capacity, resulting from poor flocculation of photo-fermentative bacteria. Materials such as activated carbon fibers (ACFs) and solar optical fibers can be utilized for immobilization of photo-fermentative bacteria to aid continuous hydrogen gas production (Xie et al., 2012).

\subsubsection{Photocatalytic hybrid sequencing batch reactor (PHSBR)}

A PHSBR was developed to integrate photocatalytic process and sequencing batch reactor into a single system for simultaneous photodegradation and biodegradation processes reaction. The photocatalytic process partially oxidized the biological persistent compound to produce biodegradable intermediates. Laboratory test revealed that simultaneous reaction allowed higher mineralization rates and the stability of biodegradation performances indicated the effectiveness of the simultaneous reaction. The removal efficiency continuously increased with time indicating the adaptation of microorganism to pollutant toxicity (Yusoff et al., 2018).

Other existing hybrid systems include: the attached-growth sequencing batch reactor, fluidized bed reactor, expended bed reactor, immersed media systems, porous support systems, sludge tank halved sequencing batch reactor (STH-SBR), iron-flocculation SBR and acidogenic co-fermentation, SBR coupled with a micro-aeration system, double-layer-packed sequencing biofilm batch reactor, double sludge switching SBR (DSS-SBR), internal-circulate sequencing batch airlift reactor, smart sequencing batch reactor, alternating pumped sequencing batch biofilm reactor, sequencing batch membrane aerated biofilm reactor (SBMABR). 


\section{Table 11. Specific advantages of various hybrid SBR configurations}

\begin{tabular}{|c|c|c|}
\hline Configuration & Advantages & Ref. \\
\hline $\begin{array}{l}\text { Algae-based sequencing } \\
\text { batch suspended biofilm } \\
\text { reactor (A-SBSBR) }\end{array}$ & $\begin{array}{l}\text { - Suspended carriers provide an enabling environment for algae enrichment } \\
\text { - Lower HRT and SRT than in the traditional biological systems } \\
\text { - Independent sludge discharge and carrier's replacement could be used to separate sludge and algae SRT } \\
\text { - Carriers replacement reduces pollution caused by algae loss or death }\end{array}$ & $\begin{array}{l}\text { (Tang et al., } \\
2018)\end{array}$ \\
\hline $\begin{array}{l}\text { An airlift loop sequencing } \\
\text { batch biofilm reactor }\end{array}$ & $\begin{array}{l}\text { - Integrating nitrification and denitrifying dephosphatation in one reactor for simultaneous phosphorus and nitrogen removal } \\
\text { - Competition between nitrifiers and denitrifying phosphorus removal bacteria in biofilm could be avoided by the reactor. }\end{array}$ & $\begin{array}{l}\text { (Z. Y. Zhang } \\
\text { et al., 2006) }\end{array}$ \\
\hline $\begin{array}{l}\text { Micro-electrolysis in } \\
\text { Sequencing Batch Reactor }\end{array}$ & $\begin{array}{l}\text { - Simple and convenient and centralized automated operating system } \\
\text { - Reduced safety risks } \\
\text { - Steady treatment effect } \\
\text { - Less area requirement alongside construction, operating and maintenance cost }\end{array}$ & $\begin{array}{l}\text { (T. Duan et } \\
\text { al., } 2012 \text {; } \\
\text { Ying, Xu, et } \\
\text { al., 2012) }\end{array}$ \\
\hline $\begin{array}{l}\text { Pressurized sequencing batch } \\
\text { reactor }\end{array}$ & $\begin{array}{l}\text { - Improves aeration efficiency standard and decreased sludge generation resulting to lower sludge disposal cost. } \\
\text { - Increases DO with increased contact time between air flashes and wastewater threefold }\end{array}$ & $\begin{array}{l}\text { (Elkaramany } \\
\text { et al., 2018; } \\
\text { Y. Zhang et } \\
\text { al., 2017) }\end{array}$ \\
\hline $\begin{array}{l}\text { Granular sequencing batch } \\
\text { reactor }\end{array}$ & $\begin{array}{l}\text { - Lower energy consumption, smaller footprint, good settling ability } \\
\text { - Diverse microbial species and high biomass retention } \\
\text { - High rate SNDPR }\end{array}$ & $\begin{array}{l}\text { (F. Y. Chen } \\
\text { et al., 2011) } \\
(\mathrm{He} \text { et al., } \\
2016) \\
(\mathrm{He} \text { et al., } \\
2020)\end{array}$ \\
\hline $\begin{array}{l}\text { Fixed bed sequencing batch } \\
\text { reactor (FBSBR) }\end{array}$ & $\begin{array}{l}\text { - High SND } \\
\text { - Less excess sludge generation }\end{array}$ & $\begin{array}{l}\text { (Rahimi et } \\
\text { al., 2011) } \\
\text { (Koupaie et } \\
\text { al., 2011) }\end{array}$ \\
\hline $\begin{array}{l}\text { Integrated fixed-film } \\
\text { activated sludge sequencing } \\
\text { batch reactor (IFAS-SBR) }\end{array}$ & $\begin{array}{l}\text { - Resistance to adverse shock load and reduced capital cost of upgrading existing reaction tanks } \\
\text { - Reduces the risk of active biomass loss } \\
\text { - Improves process capacity while providing system stability }\end{array}$ & $\begin{array}{l}\text { (Shao et al., } \\
\text { 2018) }\end{array}$ \\
\hline $\begin{array}{l}\text { Moving bed sequencing batch } \\
\text { reactor (MBSBR) }\end{array}$ & $\begin{array}{l}\text { - Flexible operation, discharge control, lower footprint and tolerance to organic shock and toxic loads } \\
\text { - The use of inexpensive porous media, robustness against starvation periods and total purification of pollutants } \\
\text { - No need to return sludge }\end{array}$ & $\begin{array}{l}\text { (Rahimi et } \\
\text { al., 2011) } \\
\text { (Malakootian } \\
\text { et al., 2020) }\end{array}$ \\
\hline $\begin{array}{l}\text { Membrane coupled } \\
\text { sequencing batch reactor }\end{array}$ & $\begin{array}{l}\text { - Reduce SBR cycle length, smaller footprint, less sludge production and higher volumetric loading rates } \\
\text { - Avoiding the formation of byproducts. } \\
\text { - Compactness and superior water reuse potential } \\
\text { - Shorter HRT and longer SRT } \\
\text { - Ease and economical in operation }\end{array}$ & $\begin{array}{l}\text { (Arrojo et al., } \\
2005 ; \\
\text { Fakhru'l- } \\
\text { Razi et al., } \\
2010 \text {; } \\
\text { Scheumann } \\
\& \quad \text { Kraume, } \\
\text { 2009; S. N. }\end{array}$ \\
\hline
\end{tabular}




\begin{tabular}{|c|c|c|}
\hline & & $\begin{array}{l}\text { Xu et al., } \\
2014)\end{array}$ \\
\hline $\begin{array}{l}\text { Ultrasound-induced } \\
\text { sequencing batch reactor }\end{array}$ & $\begin{array}{l}\text { - Technological flexibility and superior economic efficiency } \\
\text { - Suitable for wastewater co-treatment with significantly larger percentage of leachate } \\
\text { - No chemical reagents required }\end{array}$ & $\begin{array}{l}\text { (Neczaj et } \\
\text { al., 2005) } \\
\text { (Grosser et } \\
\text { al., 2019) } \\
\text { (Jin et al., } \\
\text { 2013) } \\
\text { (R. N. Zhang } \\
\text { et al., 2011) }\end{array}$ \\
\hline $\begin{array}{l}\text { Photo-sequencing batch } \\
\text { reactors (PSBRs) }\end{array}$ & $\begin{array}{l}\text { - Reduced carbon dioxide generation. } \\
\text { - Energy-saving due to low aeration requirement } \\
\end{array}$ & $\begin{array}{l}\text { (Meng et al., } \\
2019)\end{array}$ \\
\hline $\begin{array}{l}\text { Photo-fermentative } \\
\text { sequencing batch reactor } \\
\text { (PFSBR) }\end{array}$ & $\begin{array}{l}\text { - High theoretical hydrogen yield, none oxygen evolution and utilization of metabolites from dark fermentation. } \\
\text { - Ability to convert wide spectrum of light in to hydrogen gas }\end{array}$ & $\begin{array}{l}\text { (Xie et al., } \\
2012)\end{array}$ \\
\hline
\end{tabular}




\subsection{Conclusion}

The arbitrary disposal of waste at landfill sites can lead to uncontrollable displacement of leachate through the soil, surface water, and sometimes groundwater which poses a major public health environmental threat resulting from its constituents toxic and recalcitrant nature. Thus, regulations require the treatment of hazardous leachate components before discharge in order to avoid polluting water supplies and put off serious and permanent toxicity. The basic difficulty in leachate treatment is the selection of combined reasonable, economical, and efficient processes and technologies. This is due its high-strength organic content, complex chemical structure, variable composition and seasonally diverse volume. Currently, there is no single widely acceptable method documented for proper treatment of leachate as conventional wastewater treatment processes cannot achieve a satisfactory level for degrading toxic substances present. Numerous techniques have been put in during leachate degradation, showing different degrees of effectiveness. Therefore, this article presented a comprehensive review of existing research articles on the merits and demerits of various adopted methods. The article stressed on the application and efficiency of SBR system treating landfill leachate. The article further analyzed the effect of different materials, processes, strategies and configurations on leachate treatment. Environmental and operational parameters that affect SBR system were critically discussed.

This study, however, note the following:

- There is a definitive relationship between efficacy of the treatment and environmental/operational parameters as they highly influence the performance of the SBR system. These can be ascertained by observing their influence on biological dephosphatation, nitrification and denitrification, impact on the microbial community structure and population, granulation, toxicity, biofilm formation, substrate storage and utilization. They also help in understanding floc structure, properties, and mechanisms of bioflocculation.

- The efficiency and effect of individual materials under short- and long-term exposures depends on the correlation between the material and leachate age and condition. Adding composite adsorbents and plastic media into the reactor, remarkably increase biofilm formation and regulation, specific reactor surface area with improved contaminant removal.

- The improvement of the conventional SBRs involved the development of different strategies such as algalbacterial symbiosis, quorum sensing, cometabolism, augmentation. These strategies have the potential to withstand high toxic shocks and mitigate their effects, accelerate the acclimation period for the system, allow microbes to degrade a wide range of refractory organics and built a growing environment for functional dominant bacteria, enhance enzymatic activity and granule cultivation, avoid biomass washout, accelerate the sedimentation process of cells, mediate the production of EPS, substantially reduce aeration requirements and allow simultaneous removal of contaminants. Interestingly, these strategies pave way for SBR to be developed into a promising, sustainable and cost-effective technology giving rise to less by-products.

- The performance of a hybrid SBR depends on the nature of modification carried out as different modification materials, methods and conditions offer variable properties to the system. They have been proven for rapid startup of the reactor, low energy requirements, greater biomass retention, better resistance to inhibitory effects, ability to grow different types of bacteria, volumetric efficiency, low footprint, stability and resistance to shock loads

- Optimization algorithm are usually studied for new materials, strategies, processes, and configurations for better performance. Going by this, authors suggests the application of molecular docking simulation to identify the binding interactions between pollutants and materials (adsorbents, nanoparticles, membranes, biofilters, biofilm carriers etc) and the energy of which a molecule is attached to a specific receptor site.

\section{Acknowledgement}

The study enjoyed the support of Universiti Teknologi PETRONAS (UTP), Malaysia through its Graduate Assistantship Scheme (GA).

\section{Declaration of Interest Statement}

Authors declare that there is no conflict of interest

\section{References}

Abd Nasir, M. A., Jahim, J. M., Abdul, P. M., Silvamany, H., Maaroff, R. M., \& Yunus, M. F. M. (2019). The use of acidified palm oil mill effluent for thermophilic biomethane production by changing the hydraulic retention time in anaerobic sequencing batch reactor. International Journal of Hydrogen Energy, 44(6), 3373-3381. doi:10.1016/j.ijhydene.2018.06.149 
Abuabdou, S. M., Ahmad, W., Aun, N. C., \& Bashir, M. J. J. J. o. C. P. (2020). A review of anaerobic membrane bioreactors (AnMBR) for the treatment of highly contaminated landfill leachate and biogas production: effectiveness, limitations and future perspectives. 255, 120215.

Abubakar, S., Latiff, A., Lawal, I., \& Jagaba, A. J. A. J. E. R. (2016). Aerobic treatment of kitchen wastewater using sequence batch reactor (SBR) and reuse for irrigation landscape purposes. 5(5), 23-31.

Abubakar, S., Lawal, I., Hassan, I., \& Jagaba, A. J. A. J. o. E. R. (2016). Quality water analysis of public and private boreholes (a case study of Azare Town, Bauchi, Nigeria). 5(2), 204-208.

Al-dhawi, B. N., Kutty, S. R., Almahbashi, N. M., Noor, A., \& Jagaba, A. H. ORGANICS REMOVAL FROM DOMESTIC WASTEWATER UTILIZING PALM OIL CLINKER (POC) MEDIA IN A SUBMERGED ATTACHED GROWTH SYSTEMS.

Alattabi, A. W., Harris, C. B., Alkhaddar, R. M., Hashim, K. S., Ortoneda-Pedrola, M., \& Phipps, D. (2017). Improving sludge settleability by introducing an innovative, two-stage settling sequencing batch reactor. Journal of Water Process Engineering, 20, 207-216. doi:10.1016/j.jwpe.2017.11.004

Alattabi, A. W., Harris, C. B., Alkhaddar, R. M., Ortoneda-Pedrola, M., \& Alzeyadi, A. T. (2019). An investigation into the effect of MLSS on the effluent quality and sludge settleability in an aerobic-anoxic sequencing batch reactor (AASBR). Journal of Water Process Engineering, 30. doi:10.1016/j.jwpe.2017.08.017

Almahbashi, N., Kutty, S., Ayoub, M., Noor, A., Salihi, I., Al-Nini, A., ... Ghaleb, A. J. A. S. E. J. (2020). Optimization of Preparation Conditions of Sewage sludge based Activated Carbon.

Aluko, O. O., \& Sridhar, M. K. C. (2013). Evaluation of leachate treatment by trickling filter and sequencing batch reactor processes in Ibadan, Nigeria. Waste Management \& Research, 31(7), 700-705. doi:10.1177/0734242×13485867

Antileo, C., Werner, A., Ciudad, G., Munoz, C., Bornhardt, C., Jeison, D., \& Urrutia, H. (2006). Novel operational strategy for partial nitrification to nitrite in a sequencing batch rotating disk reactor. Biochemical Engineering Journal, 32(2), 69-78. doi:10.1016/j.bej.2006.09.003

ARMCANZ, A. (1997). Australian guidelines for sewerage systems-effluent management. In: Australian Government Publishing Service, Canberra.

Arrojo, B., Mosquera-Corra, A., Garrido, J. M., Mendez, R., Ficara, E., \& Malpei, F. (2005). A membrane coupled to a sequencing batch reactor for water reuse and removal of coliform bacteria. Desalination, 179(1-3), 109-116. doi:10.1016/j.desal.2004.11.059

Arun, S., Manikandan, N. A., Pakshirajan, K., \& Pugazhenthi, G. (2019). Novel shortcut biological nitrogen removal method using an algae-bacterial consortium in a photo-sequencing batch reactor: Process optimization and kinetic modelling. Journal of Environmental Management, 250. doi:10.1016/j.jenvman.2019.109401

Aziz, S. Q., Aziz, H. A., \& Yusoff, M. S. (2011a). Optimum Process Parameters for the Treatment of Landfill Leachate Using Powdered Activated Carbon Augmented Sequencing Batch Reactor (SBR) Technology. Separation Science and Technology, 46(15), 2348-2359. doi:10.1080/01496395.2011.595753

Aziz, S. Q., Aziz, H. A., \& Yusoff, M. S. (2011b). Powdered activated carbon augmented double reactsettle sequencing batch reactor process for treatment of landfill leachate. Desalination, 277(13), 313-320. doi:10.1016/j.desal.2011.04.046

Aziz, S. Q., Aziz, H. A., Yusoff, M. S., \& Bashir, M. J. K. (2011). Landfill leachate treatment using powdered activated carbon augmented sequencing batch reactor (SBR) process: Optimization by response surface methodology. Journal of Hazardous Materials, 189(1-2), 404-413. doi:10.1016/j.jhazmat.2011.02.052

Aziz, S. Q., Aziz, H. A., Yusoff, M. S., Mojiri, A., \& Abu Amr, S. S. (2012). Adsorption isotherms in landfill leachate treatment using powdered activated carbon augmented sequencing batch reactor 
technique: Statistical analysis by response surface methodology. International Journal of Chemical Reactor Engineering, 10. doi:10.1515/1542-6580.3112

Bezerra, R. A., do Canto, C. S. A., Rodrigues, J. A. D., Ratusznei, S. M., Zaiat, M., \& Foresti, E. (2009). Effect of specific feed volume on the performance of an anaerobic sequencing batch biofilm reactor (AnSBBR) with circulation treating different wastewaters under different organic loads. Afinidad, 66(543), 388-397.

Bove, D., Merello, S., Frumento, D., Arni, S. A., Aliakbarian, B., Converti, A. J. C. E., \& Technology. (2015). A critical review of biological processes and technologies for landfill leachate treatment. 38(12), 2115-2126.

Bu, L., Wang, K., Zhao, Q. L., Wei, L. L., Zhang, J., \& Yang, J. C. (2010). Characterization of dissolved organic matter during landfill leachate treatment by sequencing batch reactor, aeration corrosive cell-Fenton, and granular activated carbon in series. Journal of Hazardous Materials, 179(1-3), 1096-1105. doi:10.1016/j.jhazmat.2010.03.118

Capodici, M., Di Trapani, D., \& Viviani, G. (2014). Co-treatment of landfill leachate in laboratory-scale sequencing batch reactors: analysis of system performance and biomass activity by means of respirometric techniques. Water Science and Technology, 69(6), 1267-1274. doi:10.2166/wst.2014.005

Carvalho, G., Meyer, R. L., Yuan, Z. G., \& Keller, J. (2006). Differential distribution of ammonia- and nitrite-oxidising bacteria in flocs and granules from a nitrifying/denitrifying sequencing batch reactor. Enzyme and Microbial Technology, 39(7), 1392-1398. doi:10.1016/j.enzmictec.2006.03.024

Chao, C. F., Zhao, Y. X., Jayant, K., Ji, M., Wang, Z. J., \& Li, X. (2020). Simultaneous removal of COD, nitrogen and phosphorus and the tridimensional microbial response in a sequencing batch biofilm reactor: with varying C/N/P ratios. Biochemical Engineering Journal, 154. doi:10.1016/j.bej.2019.04.017

Chen, F. Y., Liu, Y. Q., Tay, J. H., \& Ning, P. (2011). Operational strategies for nitrogen removal in granular sequencing batch reactor. Journal of Hazardous Materials, 189(1-2), 342-348. doi:10.1016/j.jhazmat.2011.02.041

Chen, J., Wang, R. X., Wang, X. J., Chen, Z. G., Feng, X. H., \& Qin, M. Z. (2019). Response of nitritation performance and microbial community structure in sequencing biofilm batch reactors filled with different zeolite and alkalinity ratio. Bioresource Technology, 273, 487-495. doi:10.1016/j.biortech.2018.11.020

Chen, M., He, S., Yi, Q., \& Yang, M. (2010). Effect of chloride concentration on nitrogen removal from landfill leachate in sequencing batch reactor after MAP pretreatment. Water Science and Technology, 62(7), 1574-1579. doi:10.2166/wst.2010.443

Chinade, A. U., Umar, S., Osinubi, K. J. J. I. R. J. o. E., \& Technology. (2017). Effect of municipal solid waste leachate on the strength of compacted tropical soil for landfill liner. 4(6), 3248-3253.

Chu, Y. Y., Zhang, D. H., \& Xu, D. M. (2008). Advanced treatment of landfill leachate from a sequencing batch reactor (SBR) by electrochemical oxidation process. Journal of Environmental Engineering and Science, 7(6), 627-633. doi:10.1139/s08-035

Ciggin, A. S., Rossetti, S., Majone, M., \& Orhon, D. (2012). Effect of feeding regime and the sludge age on the fate of acetate and the microbial composition in sequencing batch reactor. Journal of Environmental Science and Health Part a-Toxic/Hazardous Substances \& Environmental Engineering, 47(2), 192-203. doi:10.1080/10934529.2012.640556

Contrera, R. C., Silva, K. C. D., Morita, D. M., Rodrigues, J. A. D., Zaiat, M., \& Schalch, V. (2014). Firstorder kinetics of landfill leachate treatment in a pilot-scale anaerobic sequence batch biofilm reactor. Journal of Environmental Management, 145, 385-393.

doi:10.1016/j.jenvman.2014.07.013 
Costa, A. M., Alfaia, R. G. d. S. M., \& Campos, J. C. J. J. o. e. m. (2019). Landfill leachate treatment in Brazil-An overview. 232, 110-116.

Cramer, M., Tranckner, J., \& Kotzbauer, U. Kinetic of denitrification and enhanced biological phosphorous removal (EBPR) of a trickling filter operated in a sequence-batch-reactor-mode (SBR-TF). Environmental Technology. doi:10.1080/09593330.2019.1709564

da Costa, R. H. R., Souto, V. S., Prelhaz, A. T. S., Neto, L. G. L., \& Wolff, D. B. (2008). Utilization of a hybrid sequencing batch reactor (HSBR) as a decentralized system of domestic wastewater treatment. Water Science and Technology, 57(12), 1951-1956. doi:10.2166/wst.2008.318

Dabaghian, Z., Peyravi, M., Jahanshahi, M., \& Rad, A. S. J. C. R. (2018). Potential of Advanced Nanostructured Membranes for Landfill Leachate Treatment: A Review. 5(2), 119-138.

Datta, T., Liu, Y. J., \& Goel, R. (2009). Evaluation of simultaneous nutrient removal and sludge reduction using laboratory scale sequencing batch reactors. Chemosphere, 76(5), 697-705. doi:10.1016/j.chemosphere.2009.02.040

Daverey, A., Chen, Y. C., Dutta, K., Huang, Y. T., \& Lin, J. G. (2015). Start-up of simultaneous partial nitrification, anammox and denitrification (SNAD) process in sequencing batch biofilm reactor using novel biomass carriers. Bioresource Technology, 190, 480-486. doi:10.1016/j.biortech.2015.02.064

Deng, Y. F., Zhang, X. L., Miao, Y., \& Hu, B. (2016). Exploration of rapid start-up of the CANON process from activated sludge inoculum in a sequencing biofilm batch reactor (SBBR). Water Science and Technology, 73(3), 535-542. doi:10.2166/wst.2015.518

Dereli, R. K., Clifford, E., Casey, E. J. C. R. i. E. S., \& Technology. (2020). Co-treatment of leachate in municipal wastewater treatment plants: Critical issues and emerging technologies. 1-50.

Dionisi, D., Majone, M., Levantesi, C., Bellani, A., \& Fuoco, A. (2006). Effect of feed length on settleability, substrate uptake and storage in a sequencing batch reactor treating an industrial wastewater. Environmental Technology, 27(8), 901-908. doi:10.1080/09593332708618700

Dogaris, I., Ammar, E., Philippidis, G. P. J. W. J. o. M., \& Biotechnology. (2020). Prospects of integrating algae technologies into landfill leachate treatment. 36(3), 1-25.

Du, R., Cao, S. B., Li, B. K., Wang, S. Y., \& Peng, Y. Z. (2017). Simultaneous domestic wastewater and nitrate sewage treatment by DEnitrifying AMmonium OXidation (DEAMOX) in sequencing batch reactor. Chemosphere, 174, 399-407. doi:10.1016/j.chemosphere.2017.02.013

Duan, T., Xing, M. Y., Li, M. Z., Liu, Z. Z., Liu, W., \& Yang, J. (2012). Treatment of Cotton Pulp Black Liquor Using Micro-electrolysis in Sequencing Batch Reactor. In D. Wang (Ed.), Advanced Materials in Microwaves and Optics (Vol. 500, pp. 180-186).

Duan, Y., Liu, Y. S., Zhang, M. M., Li, Y. Y., Zhu, W., Hao, M. Y., \& Ma, S. Y. (2020). Start-up and operational performance of the partial nitrification process in a sequencing batch reactor (SBR) coupled with a micro-aeration system. Bioresource Technology, 296. doi:10.1016/j.biortech.2019.122311

Dutta, A., \& Sarkar, S. (2015). Sequencing Batch Reactor for Wastewater Treatment: Recent Advances. Current Pollution Reports, 1(3), 177-190. doi:10.1007/s40726-015-0016-y

El-Fadel, M., Matar, F., \& Hashisho, J. (2013). Combined coagulation-flocculation and sequencing batch reactor with phosphorus adjustment for the treatment of high-strength landfill leachate: Experimental kinetics and chemical oxygen demand fractionation. Journal of the Air \& Waste Management Association, 63(5), 591-604. doi:10.1080/10962247.2013.775086

Elkaramany, H. M., Elbaz, A. A., Mohamed, A. N., \& Sakr, A. H. (2018). Improving the biological treatment of waste water using pressurised sequencing batch reactor. Journal of Environmental Engineering and Science, 13(2), 37-43. doi:10.1680/jenes.17.00029

Esparza-Soto, M., Nunez-Hernandez, S., \& Fall, C. (2011). Spectrometric characterization of effluent organic matter of a sequencing batch reactor operated at three sludge retention times. Water Research, 45(19), 6555-6563. doi:10.1016/j.watres.2011.09.057 
Fakhru'I-Razi, A., Pendashteh, A., Abidin, Z. Z., Abdullah, L. C., Biak, D. R. A., \& Madaeni, S. S. (2010). Application of membrane-coupled sequencing batch reactor for oilfield produced water recycle and beneficial re-use. Bioresource Technology, 101(18), 6942-6949. doi:10.1016/j.biortech.2010.04.005

Fernandes, A., Pacheco, M., Ciríaco, L., \& Lopes, A. J. A. C. B. E. (2015). Review on the electrochemical processes for the treatment of sanitary landfill leachates: present and future. 176, 183-200.

Fernandes, H., Jungles, M. K., Hoffmann, H., Antonio, R. V., \& Costa, R. H. R. (2013). Full-scale sequencing batch reactor (SBR) for domestic wastewater: Performance and diversity of microbial communities. Bioresource Technology, 132, 262-268. doi:10.1016/j.biortech.2013.01.027

Ferrer-Polonio, E., Fernandez-Navarro, J., Alonso-Molina, J. L., Bes-Pia, A., Amoros, I., \& Mendoza-Roca, J. A. (2019). Changes in the process performance and microbial community by addition of the metabolic uncoupler 3,3 ',4 ',5-tetrachlorosalicylanilide in sequencing batch reactors. Science of the Total Environment, 694. doi:10.1016/j.scitotenv.2019.133726

Fongsatitkul, P., Wareham, D. G., \& Elefsiniotis, P. (2008). TREATMENT OF FOUR INDUSTRIAL WASTEWATERS BY SEQUENCING BATCH REACTORS: EVALUATION OF COD, TKN AND TP REMOVAL. Environmental Technology, 29(11), 1257-1264. doi:10.1080/09593330802308978

Foo, K., \& Hameed, B. J. J. o. h. m. (2009). An overview of landfill leachate treatment via activated carbon adsorption process. 171(1-3), 54-60.

Frank, V. B., Regnery, J., Chan, K. E., Ramey, D. F., Spear, J. R., \& Cath, T. Y. (2017). Co-treatment of residential and oil and gas production wastewater with a hybrid sequencing batch reactormembrane bioreactor process. Journal of Water Process Engineering, 17, 82-94. doi:10.1016/j.jwpe.2017.03.003

Fudala-Ksiazek, S., Luczkiewicz, A., Fitobor, K., \& Olanczuk-Neyman, K. (2014). Nitrogen removal via the nitrite pathway during wastewater co-treatment with ammonia-rich landfill leachates in a sequencing batch reactor. Environmental Science and Pollution Research, 21(12), 7307-7318. doi:10.1007/s11356-014-2641-1

Ganjian, E., Peyravi, M., Ghoreyshi, A. A., Jahanshahi, M., Khalili, S., \& Rad, A. S. (2018). Effects of perlite and caustic soda on microorganism activities of leachate in a sequence batch reactor. Environmental Technology, 39(18), 2321-2334. doi:10.1080/09593330.2017.1354923

Gao, J., Oloibiri, V., Chys, M., Audenaert, W., Decostere, B., He, Y., . . Bio/Technology. (2015). The present status of landfill leachate treatment and its development trend from a technological point of view. 14(1), 93-122.

Gao, M. C., Gao, F., Ma, B. R., Yu, N. L., She, Z. L., Zhao, C. K., . . Jin, C. J. (2019). Insights into long-term effects of amino-functionalized multi-walled carbon nanotubes (MWCNTs-NH2) on the performance, enzymatic activity and microbial community of sequencing batch reactor. Environmental Pollution, 254. doi:10.1016/j.envpol.2019.113118

Gao, S. X., He, Q. L., \& Wang, H. Y. (2020). Research on the aerobic granular sludge under alkalinity in sequencing batch reactors: Removal efficiency, metagenomic and key microbes. Bioresource Technology, 296. doi:10.1016/j.biortech.2019.122280

Gautam, P., Kumar, S., \& Lokhandwala, S. J. J. o. C. P. (2019). Advanced oxidation processes for treatment of leachate from hazardous waste landfill: a critical review. 237, 117639.

Ghaleb, A. A. S., Kutty, S. R. M., Ho, Y.-C., Jagaba, A. H., Noor, A., Al-Sabaeei, A. M., \& Almahbashi, N. M. Y. J. S. (2020). Response Surface Methodology to Optimize Methane Production from Mesophilic Anaerobic Co-Digestion of Oily-Biological Sludge and Sugarcane Bagasse. 12(5), 2116.

Ginige, M. P., Kayaalp, A. S., Cheng, K. Y., Wylie, J., \& Kaksonen, A. H. (2013). Biological phosphorus and nitrogen removal in sequencing batch reactors: effects of cycle length, dissolved oxygen concentration and influent particulate matter. Water Science and Technology, 68(5), 982-990. doi:10.2166/wst.2013.324 
Gonzalez, O., Esplugas, M., Sans, C., Torres, A., \& Esplugas, S. (2009). Performance of a Sequencing Batch Biofilm Reactor for the treatment of pre-oxidized Sulfamethoxazole solutions. Water Research, 43(8), 2149-2158. doi:10.1016/j.watres.2009.02.013

Grosser, A., Neczaj, E., Madela, M., \& Celary, P. (2019). Ultrasound-Assisted Treatment of Landfill Leachate in a Sequencing Batch Reactor. Water, 11(3). doi:10.3390/w11030516

Hajsardar, M., Borghei, S. M., Hassani, A. H., \& Takdastan, A. (2016). Simultaneous ammonium and nitrate removal by a modified intermittently aerated sequencing batch reactor (SBR) with multiple filling events. Polish Journal of Chemical Technology, 18(3), 72-80. doi:10.1515/pjct2016-0051

Hashemi, H., Zad, T. J., Derakhshan, Z., \& Ebrahimi, A. A. (2017). Determination of Sequencing Batch Reactor (SBR) Performance in Treatment of Composting Plant Leachate. Health Scope, 6(3). doi:10.5812/jhealthscope.13356

He, Q. L., Chen, L., Zhang, S. J., Chen, R. F., Wang, H. Y., Zhang, W., \& Song, J. Y. (2018). Natural sunlight induced rapid formation of water-born algal-bacterial granules in an aerobic bacterial granular photo-sequencing batch reactor. Journal of Hazardous Materials, 359, 222-230. doi:10.1016/j.jhazmat.2018.07.051

He, Q. L., Wang, H. Y., Chen, L., Gao, S. X., Zhang, W., Song, J. Y., \& Yu, J. (2020). Robustness of an aerobic granular sludge sequencing batch reactor for low strength and salinity wastewater treatment at ambient to winter temperatures. Journal of Hazardous Materials, 384. doi:10.1016/j.jhazmat.2019.121454

He, Q. L., Zhang, S. L., Zou, Z. C., Zheng, L. A., \& Wang, H. Y. (2016). Unraveling characteristics of simultaneous nitrification, denitrification and phosphorus removal (SNDPR) in an aerobic granular sequencing batch reactor. Bioresource Technology, 220, 651-655. doi:10.1016/j.biortech.2016.08.105

He, Q. L., Zhang, W., Zhang, S. L., \& Wang, H. Y. (2017). Enanced nitrogen removal in an aerobic granular sequencing batch reactor performing simultaneous nitrification, endogenous denitrification and phosphorus removal with low superficial gas velocity. Chemical Engineering Journal, 326, 12231231. doi:10.1016/j.cej.2017.06.071

Hou, Y. P., Peng, D. C., Wang, B. B., Zhang, X. Y., Pei, L. Y., \& Li, H. J. (2015). Diagnosis of the acidification and recovery of anaerobic sequencing batch reactors. Desalination and Water Treatment, 56(9), 2368-2375. doi:10.1080/19443994.2014.967306

Jagaba, A., Kutty, S., Hayder, G., Baloo, L., Abubakar, S., Ghaleb, A., . . Almahbashi, N. J. A. S. E. J. (2020). Water quality hazard assessment for hand dug wells in Rafin Zurfi, Bauchi State, Nigeria.

Jagaba, A., Kutty, S., Hayder, G., Baloo, L., Ghaleb, A., Lawal, I., .. . Umaru, I. J. A. S. E. J. (2020). Degradation of $\mathrm{Cd}, \mathrm{Cu}, \mathrm{Fe}, \mathrm{Mn}, \mathrm{Pb}$ and $\mathrm{Zn}$ by Moringa-oleifera, zeolite, ferric-chloride, chitosan and alum in an industrial effluent.

Jagaba, A., Kutty, S., Hayder, G., Latiff, A., Aziz, N., Umaru, I., . . Nasara, M. J. A. S. E. J. (2020). Sustainable use of natural and chemical coagulants for contaminants removal from palm oil mill effluent: A comparative analysis.

Jagaba, A. H., Abubakar, S., Lawal, I. M., Latiff, A. A. A., \& Umaru, I. J. I. J. o. E. M. (2018). Wastewater treatment using alum, the combinations of alum-ferric chloride, alum-chitosan, alum-zeolite and alum-moringa oleifera as adsorbent and coagulant. 2(3), 67-75.

Jagaba, A. H., Shuaibu, A., Umaru, I., Musa, S., Lawal, I. M., \& Abubakar, S. J. S. S. M. I. J. (2019). Stabilization of soft soil by incinerated sewage sludge ash from municipal wastewater treatment plant for engineering construction. 2(1), 32-44.

Jia, H. J., \& Yuan, Q. Y. (2018). Nitrogen removal in photo sequence batch reactor using algae-bacteria consortium. Journal of Water Process Engineering, 26, 108-115. doi:10.1016/j.jwpe.2018.10.003 
Jin, R. F., Liu, G. F., Li, C. L., Xu, R. J., Li, H. Y., Zhang, L. X., \& Zhou, J. T. (2013). Effects of carbon-nitrogen ratio on nitrogen removal in a sequencing batch reactor enhanced with low-intensity ultrasound. Bioresource Technology, 148, 128-134. doi:10.1016/j.biortech.2013.08.141

Jitthaisong, O., Dhanmanonda, P., Chunkao, K., \& Teejuntuk, S. J. M. A. S. (2012). Water quality from mangrove forest: The king's royally initiated laem phak bia environmental research and development project, phetchaburi province, thailand. 6(8), 1.

Kamaruddin, M. A., Yusoff, M. S., Aziz, H. A., \& Hung, Y.-T. J. A. W. S. (2015). Sustainable treatment of landfill leachate. 5(2), 113-126.

Kamaruddin, M. A., Yusoff, M. S., Rui, L. M., Isa, A. M., Zawawi, M. H., Alrozi, R. J. E. S., \& Research, P. (2017). An overview of municipal solid waste management and landfill leachate treatment: Malaysia and Asian perspectives. 24(35), 26988-27020.

Khoo, K., Tan, X., Show, P., Pal, P., Juan, J., Ling, T., .. . Quarterly, B. E. (2020). Treatment for Landfill Leachate via Physicochemical Approaches: An Overview. 34(1), 1-24.

Kim, D. H., Kim, S. H., Kim, K. Y., \& Shin, H. S. (2010). Experience of a pilot-scale hydrogen-producing anaerobic sequencing batch reactor (ASBR) treating food waste. International Journal of Hydrogen Energy, 35(4), 1590-1594. doi:10.1016/j.ijhydene.2009.12.041

Kiso, Y., Jung, Y. J., Park, M. S., Wang, W. H., Shimase, M., Yamada, T., \& Min, K. S. (2005). Coupling of sequencing batch reactor and mesh filtration: Operational parameters and wastewater treatment performance. Water Research, 39(20), 4887-4898. doi:10.1016/j.watres.2005.05.025

Klimiuk, E., \& Kulikowska, D. (2005). The influence of operational conditions in sequencing batch reactors on removal of nitrogen and organics from municipal landfill leachate. Waste Management \& Research, 23(5), 429-438. doi:10.1177/0734242x05058579

Klodowska, I., Rodziewicz, J., \& Janczukowicz, W. (2018). The Influence of Electrical Current Density and Type of the External Source of Carbon on Nitrogen and Phosphorus Efficiency Removal in the Sequencing Batch Biofilm Reactor. Journal of Ecological Engineering, 19(5), 172-179. doi:10.12911/22998993/89811

Kornaros, M., Marazioti, C., \& Lyberatos, G. (2008). A pilot scale study of a sequencing batch reactor treating municipal wastewater operated via the UP-PND process. Water Science and Technology, 58(2), 435-438. doi:10.2166/wst.2008.366

Koupaie, E. H., Moghaddam, M. R. A., \& Hashemi, H. (2011). COMPARISON OF OVERALL PERFORMANCE BETWEEN MOVING-BED AND CONVENTIONAL SEQUENCING BATCH REACTOR. Iranian Journal of Environmental Health Science \& Engineering, 8(3), 235-244.

Kuang, F. G., Li, Y. C., He, L., Xia, Y. Q., Li, S. B., \& Zhou, J. (2018). Cometabolism degradation of lignin in sequencing batch biofilm reactors. Environmental Engineering Research, 23(3), 294-300. doi:10.4491/eer.2017.201

Kulkarni, P. M. (2012). Effect of shock and mixed loading on the performance of SND based sequencing batch reactors (SBR) degrading nitrophenols. Water Research, 46(7), 2405-2414. doi:10.1016/j.watres.2012.02.008

Kurniawan, T. A., Lo, W.-h., \& Chan, G. Y. J. J. o. h. m. (2006). Physico-chemical treatments for removal of recalcitrant contaminants from landfill leachate. 129(1-3), 80-100.

Kurniawan, T. A., Lo, W., Chan, G., \& Sillanpää, M. E. J. J. o. E. M. (2010). Biological processes for treatment of landfill leachate. 12(11), 2032-2047.

Laitinen, N., Luonsi, A., \& Vilen, J. (2006). Landfill leachate treatment with sequencing batch reactor and membrane bioreactor. Desalination, 191(1-3), 86-91. doi:10.1016/j.desal.2005.08.012

Laitinen, N., Luonsi, A., \& Vilen, J. J. D. (2006). Landfill leachate treatment with sequencing batch reactor and membrane bioreactor. 191(1-3), 86-91.

Langone, M., Yan, J., Haaijer, S. C. M., Op den Camp, H. J. M., Jetten, M. S. M., \& Andreottola, G. (2014). Coexistence of nitrifying, anammox and denitrifying bacteria in a sequencing batch reactor. Frontiers in Microbiology, 5. doi:10.3389/fmicb.2014.00028 
Li, C., Liu, S. F., Ma, T., Zheng, M. S., \& Ni, J. R. (2019). Simultaneous nitrification, denitrification and phosphorus removal in a sequencing batch reactor (SBR) under low temperature. Chemosphere, 229, 132-141. doi:10.1016/j.chemosphere.2019.04.185

Li, J., Qiang, Z. M., Yu, D. S., Wang, D., Zhang, P. Y., \& Li, Y. (2016). Performance and microbial community of simultaneous anammox and denitrification (SAD) process in a sequencing batch reactor. Bioresource Technology, 218, 1064-1072. doi:10.1016/j.biortech.2016.07.081

Li, Q., Wang, S. P., Zhang, P. D., Yu, J. J., Qiu, C. S., \& Zheng, J. F. (2018). Influence of temperature on an Anammox sequencing batch reactor (SBR) system under lower nitrogen load. Bioresource Technology, 269, 50-56. doi:10.1016/j.biortech.2018.08.057

Li, S. Y., Fei, X. N., Cao, L. Y., \& Chi, Y. Z. (2019). Insights into the effects of carbon source on sequencing batch reactors: Performance, quorum sensing and microbial community. Science of the Total Environment, 691, 799-809. doi:10.1016/j.scitotenv.2019.07.191

Li, Y. C., Zhou, J., Gong, B. Z., Wang, Y. M., \& He, Q. (2016). Cometabolic degradation of lincomycin in a Sequencing Batch Biofilm Reactor (SBBR) and its microbial community. Bioresource Technology, 214, 589-595. doi:10.1016/j.biortech.2016.04.085

Li, Z. M., Wang, S. Y., Zhang, W. T., Miao, L., Cao, T. H., \& Peng, Y. Z. (2014). Nitrogen removal from medium-age landfill leachate via post-denitrification driven by PHAs and glycogen in a single sequencing batch reactor. Bioresource Technology, 169, 773-777. doi:10.1016/j.biortech.2014.06.076

Liao, B. Q., Droppo, I. G., Leppard, G. G., \& Liss, S. N. (2006). Effect of solids retention time on structure and characteristics of sludge flocs in sequencing batch reactors. Water Research, 40(13), 25832591. doi:10.1016/j.watres.2006.04.043

Lim, J. W., Lim, P. E., \& Seng, C. E. (2012). Enhancement of nitrogen removal in moving bed sequencing batch reactor with intermittent aeration during REACT period. Chemical Engineering Journal, 197, 199-203. doi:10.1016/j.cej.2012.05.036

Lim, P. E., Lim, S. P., Seng, C. E., \& Noor, A. M. (2010). Treatment of landfill leachate in sequencing batch reactor supplemented with activated rice husk as adsorbent. Chemical Engineering Journal, 159(1-3), 123-128. doi:10.1016/j.cej.2010.02.064

Liu, J. X., Shi, S. N., Ji, X. Y., Jiang, B., Xue, L. L., Li, M. D., \& Tan, L. (2017). Performance and microbial community dynamics of electricity-assisted sequencing batch reactor (SBR) for treatment of saline petrochemical wastewater. Environmental Science and Pollution Research, 24(21), 1755617565. doi:10.1007/s11356-017-9446-y

Liu, R. B., Zhao, Y. Q., Zhao, J. H., Xu, L., \& Sibille, C. (2017). Embedding constructed wetland in sequencing batch reactor for enhancing nutrients removal: A comparative evaluation. Journal of Environmental Management, 192, 302-308. doi:10.1016/j.jenvman.2017.01.080

Liu, X. H., Peng, Y., Wu, C. Y., Akio, T., \& Peng, Y. Z. (2008). Nitrous oxide production during nitrogen removal from domestic wastewater in lab-scale sequencing batch reactor. Journal of Environmental Sciences, 20(6), 641-645. doi:10.1016/s1001-0742(08)62106-3

Liu, Y., Lin, Y. M., \& Tay, J. H. (2005). The elemental compositions of P-accumulating microbial granules developed in sequencing batch reactors. Process Biochemistry, 40(10), 3258-3262. doi:10.1016/j.procbio.2005.03.002

Lo, K. V., \& Liao, P. H. (2007). Full-scale sequencing batch reactor system for swine wastewater treatment. Journal of Environmental Science and Health Part B-Pesticides Food Contaminants and Agricultural Wastes, 42(2), 237-240. doi:10.1080/03601230601125651

Long, B., Xuan, X. P., Yang, C. Z., Zhang, L. A., Cheng, Y. Y., \& Wang, J. Q. (2019). Stability of aerobic granular sludge in a pilot scale sequencing batch reactor enhanced by granular particle size control. Chemosphere, 225, 460-469. doi:10.1016/j.chemosphere.2019.03.048 
Long, B., Yang, C. Z., Pu, W. H., Yang, J. K., Jiang, G. S., Dan, J. F., . . Liu, F. B. (2014). Rapid cultivation of aerobic granular sludge in a pilot scale sequencing batch reactor. Bioresource Technology, 166, 57-63. doi:10.1016/j.biortech.2014.05.039

Long, B., Yang, C. Z., Pu, W. H., Yang, J. K., Shi, Y. F., Wang, J., . . Liu, F. B. (2014). The stability of aerobic granular sludge treating municipal sludge deep dewatering filtrate in a bench scale sequencing batch reactor. Bioresource Technology, 169, 244-250. doi:10.1016/j.biortech.2014.06.094

Luo, H., Zeng, Y., Cheng, Y., He, D., \& Pan, X. J. S. O. T. T. E. (2020). Recent advances in municipal landfill leachate: A review focusing on its characteristics, treatment, and toxicity assessment. 703, 135468.

Ma, B. R., Gao, F., Yu, N. L., Zhao, C. K., Li, S. S., She, Z. L., .. . Gao, M. C. (2019). Long-term impacts of carboxyl functionalized multi-walled carbon nanotubes on the performance, microbial enzymatic activity and microbial community of sequencing batch reactor. Bioresource Technology, 286. doi:10.1016/j.biortech.2019.121382

Malakootian, M., Shahamat, Y. D., \& Mahdizadeh, H. (2020). Purification of diazinon pesticide by sequencing batch moving-bed biofilm reactor after ozonation/Mg-Al layered double hydroxides pre-treated effluent. Separation and Purification Technology, 242. doi:10.1016/j.seppur.2020.116754

Mandal, P., Dubey, B. K., \& Gupta, A. K. J. W. m. (2017). Review on landfill leachate treatment by electrochemical oxidation: drawbacks, challenges and future scope. 69, 250-273.

Marin, J. C. A., Caravelli, A. H., \& Zaritzky, N. E. (2016). Nitrification and aerobic denitrification in anoxicaerobic sequencing batch reactor. Bioresource Technology, 200, 380-387. doi:10.1016/j.biortech.2015.10.024

Marsili-Libelli, S., Spagni, A., \& Susini, R. (2008). Intelligent monitoring system for long-term control of Sequencing Batch Reactors. Water Science and Technology, 57(3), 431-438. doi:10.2166/wst.2008.133

Massara, T. M., Katsou, E., Guisasola, A., Rodriguez-Caballero, A., Pijuan, M., \& Baeza, J. A. (2017). Modeling of N2O Emissions in a Full-Scale Activated Sludge Sequencing Batch Reactor. In G. Mannina (Ed.), Frontiers in Wastewater Treatment and Modelling, Ficwtm 2017 (Vol. 4, pp. 98104).

Maurina, G. Z., Rosa, L. M., Beal, L. L., Baldasso, C., Gimenez, J. R., Torres, A. P., \& Sousa, M. P. (2014). EFFECT OF INTERNAL RECIRCULATION VELOCITY IN AN ANAEROBIC SEQUENCING BATCH REACTOR (ASBR). Brazilian Journal of Chemical Engineering, 31(4), 895-903. doi:10.1590/01046632.20140314s00002895

Menezes, O., Brito, R., Hallwass, F., Florencio, L., Kato, M. T., \& Gauazza, S. (2019). Coupling intermittent micro-aeration to anaerobic digestion improves tetra-azo dye Direct Black 22 treatment in sequencing batch reactors. Chemical Engineering Research \& Design, 146, 369-378. doi:10.1016/j.cherd.2019.04.020

Meng, F. S., Xi, L. M., Liu, D. F., Huang, W. W., Lei, Z. F., Zhang, Z. Y., \& Huang, W. L. (2019). Effects of light intensity on oxygen distribution, lipid production and biological community of algalbacterial granules in photo-sequencing batch reactors. Bioresource Technology, 272, 473-481. doi:10.1016/j.biortech.2018.10.059

Miao, L., Wang, K., Wang, S. Y., Zhu, R. L., Li, B. K., Peng, Y. Z., \& Weng, D. C. (2014). Advanced nitrogen removal from landfill leachate using real-time controlled three-stage sequence batch reactor (SBR) system. Bioresource Technology, 159, 258-265. doi:10.1016/j.biortech.2014.02.058

Miao, L., Wang, S. Y., Cao, T. H., Peng, Y. Z., Zhang, M., \& Liu, Z. Y. (2016). Advanced nitrogen removal from landfill leachate via Anammox system based on Sequencing Biofilm Batch Reactor (SBBR): Effective protection of biofilm. Bioresource Technology, 220, 8-16. doi:10.1016/j.biortech.2016.06.131 
Miao, L., Wang, S. Y., Li, B. K., Cao, T. H., Xue, T. L., \& Peng, Y. Z. (2015). Advanced nitrogen removal via nitrite using stored polymers in a modified sequencing batch reactor treating landfill leachate. Bioresource Technology, 192, 354-360. doi:10.1016/j.biortech.2015.05.013

Michalska, J., Gren, I., Zur, J., Wasilkowski, D., \& Mrozik, A. (2019). Impact of the Biological Cotreatment of the Kalina Pond Leachate on Laboratory Sequencing Batch Reactor Operation and Activated Sludge Quality. Water, 11(8). doi:10.3390/w11081539

Michalska, J., Pinski, A., Zur, J., \& Mrozik, A. (2020). Analysis of the Bioaugmentation Potential of Pseudomonas putida OR45a and Pseudomonas putida KB3 in the Sequencing Batch Reactors Fed with the Phenolic Landfill Leachate. Water, 12(3). doi:10.3390/w12030906

Miqueleto, A. P., Dolosic, C. C., Pozzi, E., Foresti, E., \& Zaiat, M. (2010). Influence of carbon sources and $\mathrm{C} / \mathrm{N}$ ratio on EPS production in anaerobic sequencing batch biofilm reactors for wastewater treatment. Bioresource Technology, 101(4), 1324-1330. doi:10.1016/j.biortech.2009.09.026

Mizzouri, N. S., \& Shaaban, M. G. (2013). Individual and combined effects of organic, toxic, and hydraulic shocks on sequencing batch reactor in treating petroleum refinery wastewater. Journal of Hazardous Materials, 250, 333-344. doi:10.1016/j.jhazmat.2013.01.082

Mojiri, A., Aziz, H. A., Zaman, N. Q., Aziz, S. Q., \& Zahed, M. A. (2014). Powdered ZELIAC augmented sequencing batch reactors (SBR) process for co-treatment of landfill leachate and domestic wastewater. Journal of Environmental Management, 139, 1-14. doi:10.1016/j.jenvman.2014.02.017

Mojiri, A., Lou, Z. Y., Wang, H., Ahmad, Z., Tajuddin, R. M., Abu Amr, S. S., . . Farraji, H. (2017). Concentrated landfill leachate treatment with a combined system including electro-ozonation and composite adsorbent augmented sequencing batch reactor process. Process Safety and Environmental Protection, 111, 253-262. doi:10.1016/j.psep.2017.07.013

Mojiri, A., Ohashi, A., Ozaki, N., \& Kindaichi, T. (2018). Pollutants removal from synthetic wastewater by the combined electrochemical, adsorption and sequencing batch reactor (SBR). Ecotoxicology and Environmental Safety, 161, 137-144. doi:10.1016/j.ecoenv.2018.05.053

Mousavi, S. A., Almasi, A., Kamari, Z., Abdali, F., \& Yosefi, Z. (2015). Application of the central composite design and response surface methodology for the treatment of Kermanshah landfill leachate by a sequencing batch reactor. Desalination and Water Treatment, 56(3), 622-628. doi:10.1080/19443994.2014.938302

Narayan, R. B., Zargham, B. I., Ngambia, A., \& Riyanto, A. R. (2019). Economic and environmental impact analysis of ammoniacal nitrogen removal from landfill leachate using sequencing batch reactor: a case study from Czech Republic. Journal of Water Supply Research and Technology-Aqua, 68(8), 816-828. doi:10.2166/aqua.2019.084

Nawaz, T., Rahman, A., Pan, S., Dixon, K., Petri, B., \& Selvaratnam, T. J. P. (2020). A Review of Landfill Leachate Treatment by Microalgae: Current Status and Future Directions. 8(4), 384.

Neczaj, E., Kacprzak, M., Kamizela, T., Lach, J., \& Okoniewska, E. (2008). Sequencing batch reactor system for the co-treatment of landfill leachate and dairy wastewater. Desalination, 222(1-3), 404-409. doi:10.1016/j.desal.2007.01.133

Neczaj, E., Okoniewska, E., \& Kacprzak, M. (2005). Treatment of landfill leachate by sequencing batch reactor. Desalination, 185(1-3), 357-362. doi:10.1016/j.desal.2005.04.044

Nhat, P. T., Biec, H. N., Van, T. T. T., Van Tuan, D., Trung, N. L. H., Nghi, V. T. K., \& Dan, N. P. (2017). Stability of partial nitritation in a sequencing batch reactor fed with high ammonium strength old urban landfill leachate. International Biodeterioration \& Biodegradation, 124, 56-61. doi:10.1016/j.ibiod.2017.06.017

Ni, B. J., Xie, W. M., Liu, S. G., Yu, H. Q., Wang, Y. Z., Wang, G., \& Dai, X. L. (2009). Granulation of activated sludge in a pilot-scale sequencing batch reactor for the treatment of low-strength municipal wastewater. Water Research, 43(3), 751-761. doi:10.1016/j.watres.2008.11.009 
Omar, H., Rohani, S. J. F. o. C. S., \& Engineering. (2015). Treatment of landfill waste, leachate and landfill gas: A review. 9(1), 15-32.

Oselame, M. C., Fernandes, H., \& Costa, R. H. R. (2014). SIMULATION AND CALIBRATION OF A FULLSCALE SEQUENCING BATCH REACTOR FOR WASTEWATER TREATMENT. Brazilian Journal of Chemical Engineering, 31(3), 649-658. doi:10.1590/0104-6632.20140313s00002541

Penteado, T. Z., Santana, R. S. S., Dibiazi, A. L. B., de Pinho, S. C., Ribeiro, R., \& Tommaso, G. (2011). Effect of agitation on the performance of an anaerobic sequencing batch biofilm reactor in the treatment of dairy effluents. Water Science and Technology, 63(5), 995-1003. doi:10.2166/wst.2011.281

Pirsaheb, M., Hossini, H., Secula, M. S., Parvaneh, M., \& Ashraf, G. M. (2017). Application of high rate integrated anaerobic-aerobic/biogranular activated carbon sequencing batch reactor (IAnABioGACSBR) for treating strong municipal landfill leachate. Scientific Reports, 7. doi:10.1038/s41598-017-02936-1

Puay, N. Q., Qiu, G. L., \& Ting, Y. P. (2015). Effect of Zinc oxide nanoparticles on biological wastewater treatment in a sequencing batch reactor. Journal of Cleaner Production, 88, 139-145. doi:10.1016/j.jclepro.2014.03.081

Qiu, S. K., Hu, Y. S., Liu, R., Sheng, X. L., Chen, L. J., Wu, G. X., . . Zhan, X. M. (2019). Start up of partial nitritation-anammox process using intermittently aerated sequencing batch reactor: Performance and microbial community dynamics. Science of the Total Environment, 647, 11881198. doi:10.1016/j.scitotenv.2018.08.098

Rahimi, Y., Torabian, A., Mehrdadi, N., \& Shahmoradi, B. (2011). Simultaneous nitrificationdenitrification and phosphorus removal in a fixed bed sequencing batch reactor (FBSBR). Journal of Hazardous Materials, 185(2-3), 852-857. doi:10.1016/j.jhazmat.2010.09.098

Ranjan, K., Chakraborty, S., Verma, M., Iqbal, J., \& Kumar, R. N. (2016). Co-treatment of old landfill leachate and municipal wastewater in sequencing batch reactor (SBR): effect of landfill leachate concentration. Water Quality Research Journal of Canada, 51(4), 377-387. doi:10.2166/wqrjc.2016.020

Remmas, N., Ntougias, S., Chatzopoulou, M., \& Melidis, P. (2018). Optimization aspects of the biological nitrogen removal process in a full-scale twin sequencing batch reactor (SBR) system in series treating landfill leachate. Journal of Environmental Science and Health Part a-Toxic/Hazardous Substances \& Environmental Engineering, 53(9), 847-853. doi:10.1080/10934529.2018.1455375

Renou, S., Givaudan, J., Poulain, S., Dirassouyan, F., \& Moulin, P. J. J. o. h. m. (2008). Landfill leachate treatment: Review and opportunity. 150(3), 468-493.

Rollemberg, S. L. D., Barros, A. R. M., de Lima, J. P. M., Santos, A. F., Firmino, P. I. M., \& dos Santos, A. B. (2019). Influence of sequencing batch reactor configuration on aerobic granules growth: Engineering and microbiological aspects. Journal of Cleaner Production, 238. doi:10.1016/j.jclepro.2019.117906

Roy, D., Azaïs, A., Benkaraache, S., Drogui, P., Tyagi, R. D. J. R. i. E. S., \& Bio/Technology. (2018). Composting leachate: characterization, treatment, and future perspectives. 17(2), 323-349.

Sarti, A., Silva, A. J., Zaiat, M., \& Foresti, E. (2011). Full-scale anaerobic sequencing batch biofilm reactor for sulfate-rich wastewater treatment. Desalination and Water Treatment, 25(1-3), 13-19. doi:10.5004/dwt.2011.1864

Schaubroeck, T., Bagchi, S., De Clippeleir, H., Carballa, M., Verstraete, W., \& Vlaeminck, S. E. (2012). Successful hydraulic strategies to start up OLAND sequencing batch reactors at lab scale. Microbial Biotechnology, 5(3), 403-414. doi:10.1111/j.1751-7915.2011.00326.x

Scheumann, R., \& Kraume, M. (2009). Influence of hydraulic retention time on the operation of a submerged membrane sequencing batch reactor (SM-SBR) for the treatment of greywater. Desalination, 246(1-3), 444-451. doi:10.1016/j.desal.2008.03.066 
Schiopu, A. M., \& Gavrilescu, M. J. C. S., Air, Water. (2010). Options for the treatment and management of municipal landfill leachate: common and specific issues. 38(12), 1101-1110.

Schwitalla, P., Mennerich, A., Austermann-Haun, U., Muller, A., Dorninger, C., Daims, H., ... RonnerHolm, S. G. E. (2008). NH4+ ad-/desorption in sequencing batch reactors: simulation, laboratory and full-scale studies. Water Science and Technology, 58(2), 345-350. doi:10.2166/wst.2008.388

Sekine, M., Akizuki, S., Kishi, M., \& Toda, T. (2018). Stable nitrification under sulfide supply in a sequencing batch reactor with a long fill period. Journal of Water Process Engineering, 25, 190194. doi:10.1016/j.jwpe.2018.05.012

Shao, Y. X., Yang, S., Mohammed, A., \& Liu, Y. (2018). Impacts of ammonium loading on nitritation stability and microbial community dynamics in the integrated fixed-film activated sludge sequencing batch reactor (IFAS-SBR). International Biodeterioration \& Biodegradation, 133, 6369. doi:10.1016/j.ibiod.2018.06.002

Shariati, S. R. P., Bonakdarpour, B., Zare, N., \& Ashtiani, F. Z. (2011). The effect of hydraulic retention time on the performance and fouling characteristics of membrane sequencing batch reactors used for the treatment of synthetic petroleum refinery wastewater. Bioresource Technology, 102(17), 7692-7699. doi:10.1016/j.biortech.2011.05.065

She, Z. L., Wu, L., Wang, Q., Gao, M. C., Jin, C. J., Zhao, Y. G., . . Guo, L. (2018). Salinity effect on simultaneous nitrification and denitrification, microbial characteristics in a hybrid sequencing batch biofilm reactor. Bioprocess and Biosystems Engineering, 41(1), 65-75. doi:10.1007/s00449017-1844-5

Shen, W. H., Tao, E. P., Ning, L., Liu, T. L., \& leee. (2012). Study of Composite Fuzzy Control of Dissolved Oxygen in a Sequencing Batch Reactor Pilot Process of Synthetic Papermaking Wastewater.

Sheng, X. L., Liu, R., Song, X. Y., Chen, L. J., \& Tomoki, K. (2017). Comparative study on microbial community in intermittently aerated sequencing batch reactors (SBR) and a traditional SBR treating digested piggery wastewater. Frontiers of Environmental Science \& Engineering, 11(3). doi:10.1007/s11783-017-0929-3

Shi, X. Y., Yu, H. Q., Sun, Y. J., \& Huang, X. (2009). Characteristics of aerobic granules rich in autotrophic ammonium-oxidizing bacteria in a sequencing batch reactor. Chemical Engineering Journal, 147(2-3), 102-109. doi:10.1016/j.cej.2008.06.037

Soltani, R. D. C., Rezaee, A., Godini, H., Khataee, A. R., \& Jorfi, S. (2013). Organic matter removal under high loads in a fixed-bed sequencing batch reactor with peach pit as carrier. Environmental Progress \& Sustainable Energy, 32(3), 681-687. doi:10.1002/ep.11685

Song, Y. J., Ishii, S., Rathnayake, L., Ito, T., Satoh, H., \& Okabe, S. (2013). Development and characterization of the partial nitrification aerobic granules in a sequencing batch airlift reactor. Bioresource Technology, 139, 285-291. doi:10.1016/j.biortech.2013.04.018

Spagni, A., Lavagnolo, M. C., Scarpa, C., Vendrame, P., Rizzo, A., \& Luccarini, L. (2007). Nitrogen removal optimization in a sequencing batch reactor treating sanitary landfill leachate. Journal of Environmental Science and Health Part a-Toxic/Hazardous Substances \& Environmental Engineering, 42(6), 757-765. doi:10.1080/10934520701304435

Spagni, A., \& Marsili-Libelli, S. (2009). Nitrogen removal via nitrite in a sequencing batch reactor treating sanitary landfill leachate. Bioresource Technology, 100(2), 609-614. doi:10.1016/j.biortech.2008.06.064

Spagni, A., Marsili-Libelli, S., \& Lavagnolo, M. C. (2008). Optimisation of sanitary landfill leachate treatment in a sequencing batch reactor. Water Science and Technology, 58(2), 337-343. doi:10.2166/wst.2008.399

Stegmann, R., Heyer, K., \& Cossu, R. (2005). Leachate treatment. Paper presented at the Proceedings Sardinia. 
Su, J. J., Huang, J. F., Wang, Y. L., \& Hong, Y. Y. (2018). Treatment of duck house wastewater by a pilotscale sequencing batch reactor system for sustainable duck production. Poultry Science, 97(11), 3870-3877. doi:10.3382/ps/pey251

Sun, S. C., Cheng, X., \& Sun, D. Z. (2013). Emission of N2O from a full-scale sequencing batch reactor wastewater treatment plant: Characteristics and influencing factors. International Biodeterioration \& Biodegradation, 85, 545-549. doi:10.1016/j.ibiod.2013.03.034

Takekawa, M., Park, G., Soda, S., \& Ike, M. (2014). Simultaneous anammox and denitrification (SAD) process in sequencing batch reactors. Bioresource Technology, 174, 159-166. doi:10.1016/j.biortech.2014.10.021

Tan, K. C., Seng, C. E., Lim, P. E., Oo, C. W., Lim, J. W., \& Kew, S. L. (2016). Alteration of moving bed sequencing batch reactor operational strategies for the enhancement of nitrogen removal from stabilized landfill leachate. Desalination and Water Treatment, 57(34), 15979-15988. doi:10.1080/19443994.2015.1075427

Tang, C. C., Tian, Y., He, Z. W., Zuo, W., \& Zhang, J. (2018). Performance and mechanism of a novel algalbacterial symbiosis system based on sequencing batch suspended biofilm reactor treating domestic wastewater. Bioresource Technology, 265, 422-431. doi:10.1016/j.biortech.2018.06.033

Tella, A., \& Balogun, A.-L. J. N. H. (2020). Ensemble fuzzy MCDM for spatial assessment of flood susceptibility in Ibadan, Nigeria. 104(3), 2277-2306.

Thakur, C., Mall, I. D., \& Srivastava, V. C. (2013). EFFECT OF HYDRAULIC RETENTION TIME AND FILLING TIME ON SIMULTANEOUS BIODEGRADATION OF PHENOL, RESORCINOL AND CATECHOL IN A SEQUENCING BATCH REACTOR. Archives of Environmental Protection, 39(2), 69-80. doi:10.2478/v10265-012-0028-2

Tomaszewski, M., Cema, G., Twardowski, T., \& Ziembinska-Buczynska, A. (2018). Performance of the anammox sequencing batch reactor treating synthetic and real landfill leachate. In B. Kazmierczak, M. Kutylowska, K. Piekarska, \& P. Jadwiszczak (Eds.), 10th Conference on Interdisciplinary Problems in Environmental Protection and Engineering Eko-Dok 2018 (Vol. 44).

Trabelsi, I., Salah, S., \& Ounaeis, F. (2013). Coupling short-time sequencing batch reactor and coagulation-settling process for co-treatment of landfill leachate with raw municipal wastewater. Arabian Journal of Geosciences, 6(6), 2071-2079. doi:10.1007/s12517-011-0464-7

Tripathy, B. K., \& Kumar, M. J. J. o. e. c. e. (2017). Suitability of microwave and microwave-coupled systems for landfill leachate treatment: An overview. 5(6), 6165-6178.

Tsilogeorgis, J., Zouboulis, A., Samaras, P., \& Zambouhs, D. (2008). Application of a membrane sequencing batch reactor for landfill leachate treatment. Desalination, 221(1-3), 483-493. doi:10.1016/j.desal.2007.01.109

Umar, M., Aziz, H. A., \& Yusoff, M. S. J. W. m. (2010). Trends in the use of Fenton, electro-Fenton and photo-Fenton for the treatment of landfill leachate. 30(11), 2113-2121.

Vukovic, M., Cosic, I., Kucic, D., Kopcic, N., \& Briski, F. (2012). Biodegradation kinetics of Tobacco-waste Leachate by Activated Sludge in a Sequencing Batch Reactor (SBR). Chemical and Biochemical Engineering Quarterly, 26(3), 191-198.

Wang, J. F., Ding, L. L., Li, K., Huang, H., Hu, H. D., Geng, J. J., . . Ren, H. Q. (2018). Estimation of spatial distribution of quorum sensing signaling in sequencing batch biofilm reactor (SBBR) biofilms. Science of the Total Environment, 612, 405-414. doi:10.1016/j.scitotenv.2017.07.277

Wang, K., Li, L., Tan, F., \& Wu, D. J. A. (2018). Treatment of landfill leachate using activated sludge technology: A review. 2018.

Wang, M., Yang, H., Ergas, S. J., \& van der Steen, P. (2015). A novel shortcut nitrogen removal process using an algal-bacterial consortium in a photo-sequencing batch reactor (PSBR). Water Research, 87, 38-48. doi:10.1016/j.watres.2015.09.016 
Wang, S., Li, Z. W., Gao, M. C., She, Z. L., Guo, L., Zheng, D., ... Wang, X. J. (2017). Long-term effects of nickel oxide nanoparticles on performance, microbial enzymatic activity, and microbial community of a sequencing batch reactor. Chemosphere, 169, 387-395. doi:10.1016/j.chemosphere.2016.10.139

Wang, Y. Y., Peng, Y. Z., \& Stephenson, T. (2009). Effect of influent nutrient ratios and hydraulic retention time (HRT) on simultaneous phosphorus and nitrogen removal in a two-sludge sequencing batch reactor process. Bioresource Technology, 100(14), 3506-3512. doi:10.1016/j.biortech.2009.02.026

Wang, Z. C., Gao, M. C., Wang, S., Xin, Y. J., Ma, D., She, Z. L., . . Ren, Y. (2014). Effect of hexavalent chromium on extracellular polymeric substances of granular sludge from an aerobic granular sequencing batch reactor. Chemical Engineering Journal, 251, 165-174. doi:10.1016/j.cej.2014.04.078

Wei, D., Xue, X. D., Chen, S. W., Zhang, Y. F., Yan, L. G., Wei, Q., \& Du, B. (2013). Enhanced aerobic granulation and nitrogen removal by the addition of zeolite powder in a sequencing batch reactor. Applied Microbiology and Biotechnology, 97(20), 9235-9243. doi:10.1007/s00253-0124625-8

Wei, Y. J., Ji, M., Li, R. Y., \& Qin, F. F. (2012). Organic and nitrogen removal from landfill leachate in aerobic granular sludge sequencing batch reactors. Waste Management, 32(3), 448-455. doi:10.1016/j.wasman.2011.10.008

Wiszniowski, J., Robert, D., Surmacz-Gorska, J., Miksch, K., \& Weber, J. J. E. c. I. (2006). Landfill leachate treatment methods: A review. 4(1), 51-61.

Wu, Y. Y., Zhou, S. Q., Ye, X. Y., Chen, D. Y., Zheng, K., \& Qin, F. H. (2011). Transformation of pollutants in landfill leachate treated by a combined sequence batch reactor, coagulation, Fenton oxidation and biological aerated filter technology. Process Safety and Environmental Protection, 89(2), 112-120. doi:10.1016/j.psep.2010.10.005

Xiao, P. Y., Lu, P. L., Zhang, D. J., Han, X. K., \& Yang, Q. X. (2015). Effect of trace hydrazine addition on the functional bacterial community of a sequencing batch reactor performing completely autotrophic nitrogen removal over nitrite. Bioresource Technology, 175, 216-223. doi:10.1016/j.biortech.2014.10.084

Xiao, Y., Zeng, G. M., Yang, Z. H., Liu, Y. S., Ma, Y. H., Yang, L., . . Xu, Z. Y. (2009). Coexistence of nitrifiers, denitrifiers and Anammox bacteria in a sequencing batch biofilm reactor as revealed by PCR-DGGE. Journal of Applied Microbiology, 106(2), 496-505. doi:10.1111/j.13652672.2008.04017.x

Xie, G. J., Liu, B. F., Guo, W. Q., Ding, J., Xing, D. F., Nan, J., .. Ren, N. Q. (2012). Feasibility studies on continuous hydrogen production using photo-fermentative sequencing batch reactor. International Journal of Hydrogen Energy, 37(18), 13689-13695. doi:10.1016/j.ijhydene.2012.02.107

Xu, S. N., Wu, D. L., \& Hu, Z. Q. (2014). Impact of hydraulic retention time on organic and nutrient removal in a membrane coupled sequencing batch reactor. Water Research, 55, 12-20. doi:10.1016/j.watres.2014.01.046

Xu, Y. H., Zhou, S. Q., \& Li, H. S. (2020). Landfill Leachate Treatment Using a Combination of Heterotrophic Denitrification and Partial Nitritation in a Single Sequencing Batch Reactor. Polish Journal of Environmental Studies, 29(1), 397-408. doi:10.15244/pjoes/101614

Yang, Q., Liu, X. H., Peng, Y. Z., Wang, S. Y., Sun, H. W., \& Gu, S. B. (2009). Advanced nitrogen removal via nitrite from municipal wastewater in a pilot-plant sequencing batch reactor. Water Science and Technology, 59(12), 2371-2377. doi:10.2166/wst.2009.304

Yarimtepe, C. C., \& Oz, N. A. (2018). INVESTIGATION OF THE PRETREATMENT EFFECT OF ULTRASOUND ON ANAEROBIC SEQUENCING BATCH REACTOR TREATING LANDFILL LEACHATE. In C. A. Brebbia \& Z. Boukalova (Eds.), Water Resources Management Ix (Vol. 220, pp. 93-97). 
Yazici, H., \& Kilic, M. (2016). Effect of the Concentration Balance in Feeding Solutions on EBPR Performance of a Sequencing Batch Reactor Fed with Sodium Acetate or Glucose. Water Air and Soil Pollution, 227(10). doi:10.1007/s11270-016-3080-z

Ye, L., Peng, C. Y., Tang, B., Wang, S. Y., Zhao, K. F., \& Peng, Y. Z. (2009). Determination effect of influent salinity and inhibition time on partial nitrification in a sequencing batch reactor treating saline sewage. Desalination, 246(1-3), 556-566. doi:10.1016/j.desal.2009.01.005

Yin, W. J., Wang, K., Xu, J. T., Wu, D. J., \& Zhao, C. C. (2018). The performance and associated mechanisms of carbon transformation (PHAs, polyhydroxyalkanoates) and nitrogen removal for landfill leachate treatment in a sequencing batch biofilm reactor (SBBR). Rsc Advances, 8(74), 42329-42336. doi:10.1039/c8ra07839d

Ying, D. W., Peng, J., Xu, X. Y., Li, K., Wang, Y. L., \& Jia, J. P. (2012). Treatment of mature landfill leachate by internal micro-electrolysis integrated with coagulation: A comparative study on a novel sequencing batch reactor based on zero valent iron. Journal of Hazardous Materials, 229, 426433. doi:10.1016/j.jhazmat.2012.06.037

Ying, D. W., Xu, X. Y., Li, K., Wang, Y. L., \& Jia, J. P. (2012). Design of a novel sequencing batch internal micro-electrolysis reactor for treating mature landfill leachate. Chemical Engineering Research \& Design, 90(12), 2278-2286. doi:10.1016/j.cherd.2012.06.007

Yong, Z. J., Bashir, M. J. K., Ng, C. A., Sethupathi, S., \& Lim, J. W. (2018). A sequential treatment of intermediate tropical landfill leachate using a sequencing batch reactor (SBR) and coagulation. Journal of Environmental Management, 205, 244-252. doi:10.1016/j.jenvman.2017.09.068

Yusoff, N., Ong, S. A., Ho, L. N., Rashid, N. A., Wong, Y. S., Saad, F. N. M., . . Lee, S. L. (2018). Development of simultaneous photo-biodegradation in the photocatalytic hybrid sequencing batch reactor (PHSBR) for mineralization of phenol. Biochemical Engineering Journal, 138, 131140. doi:10.1016/j.bej.2018.07.015

Zhan, X. M., Rodgers, M., \& O'Reilly, E. (2006). Biofilm growth and characteristics in an alternating pumped sequencing batch biofilm reactor (APSBBR). Water Research, 40(4), 817-825. doi:10.1016/j.watres.2005.12.003

Zhang, D. B., Wu, X. G., Wang, Y. S., \& Zhang, H. (2014). Landfill leachate treatment using the sequencing batch biofilm reactor method integrated with the electro-Fenton process. Chemical Papers, 68(6), 782-787. doi:10.2478/s11696-013-0504-8

Zhang, J., Tian, Y., Zuo, W., Chen, L., \& Yin, L. L. (2013). Inhibition of nitrification by the metabolic uncoupler, 2,6-dichlorophenol (2,6-DCP) in a sequencing batch reactor. Chemical Engineering Journal, 233, 132-137. doi:10.1016/j.cej.2013.08.037

Zhang, L. Q., Fan, J. J., Nguyen, H. N., Li, S. G., \& Rodrigues, D. F. (2019). Effect of cadmium on the performance of partial nitrification using sequencing batch reactor. Chemosphere, 222, 913-922. doi:10.1016/j.chemosphere.2019.02.006

Zhang, L. Q., Wei, C. H., Zhang, K. F., Zhang, C. S., Fang, Q., \& Li, S. G. (2009). Effects of temperature on simultaneous nitrification and denitrification via nitrite in a sequencing batch biofilm reactor. Bioprocess and Biosystems Engineering, 32(2), 175-182. doi:10.1007/s00449-008-0235-3

Zhang, R. N., Jin, R. F., Liu, G. F., Zhou, J. T., \& Li, C. L. (2011). Study on nitrogen removal performance of sequencing batch reactor enhanced by low intensity ultrasound. Bioresource Technology, 102(10), 5717-5721. doi:10.1016/j.biortech.2011.02.112

Zhang, S. Y., Jiang, X. L., Li, M., Zhang, Q., Yuan, J. L., \& Guo, W. J. (2020). Effects of deoxygenation pretreatment and dissolved oxygen adjustment on performance of double-layer-packed sequencing biofilm batch reactor treating secondary effluent under low temperature. Journal of Cleaner Production, 258. doi:10.1016/j.jclepro.2020.120650

Zhang, Y., Jiang, W. L., Qin, Y., Wang, G. X., Xu, R. X., \& Xie, B. (2017). Dynamic changes of bacterial community in activated sludge with pressurized aeration in a sequencing batch reactor. Water Science and Technology, 75(11), 2639-2648. doi:10.2166/wst.2017.147 
Zhang, Z. Y., Zhou, J. T., Wang, J., Guo, H. Y., \& Tong, J. A. (2006). Integration of nitrification and denitrifying dephosphatation in airlift loop sequencing batch biofilm reactor. Process Biochemistry, 41(3), 599-608. doi:10.1016/j.procbio.2005.08.005

Zheng, W., Zhang, Z. Y., Liu, R., \& Lei, Z. F. (2018). Removal of veterinary antibiotics from anaerobically digested swine wastewater using an intermittently aerated sequencing batch reactor. Journal of Environmental Sciences, 65, 8-17. doi:10.1016/j.jes.2017.04.011

Zhou, H. X., \& Xu, G. R. (2019). Effect of silver nanoparticles on an integrated fixed-film activated sludgesequencing batch reactor: Performance and community structure. Journal of Environmental Sciences, 80, 229-239. doi:10.1016/j.jes.2018.12.016

Zinadini, S., Rahimi, M., Zinatizadeh, A. A., \& Mehrabadi, Z. S. (2015). High frequency ultrasound-induced sequence batch reactor as a practical solution for high rate wastewater treatment. Journal of Environmental Chemical Engineering, 3(1), 217-226. doi:10.1016/j.jece.2014.06.017

Zvimba, J. N., Mathye, M., Vadapalli, V. R. K., Swanepoel, H., \& Bologo, L. (2013). Fe(II) oxidation during acid mine drainage neutralization in a pilot-scale sequencing batch reactor. Water Science and Technology, 68(6), 1406-1411. doi:10.2166/wst.2013.389 